UNIVERSIDADE DE SÃO PAULO

FACULDADE DE FILOSOFIA, CIÊNCIAS E LETRAS DE RIBEIRÃO PRETO DEPARTAMENTO DE PSICOLOGIA PROGRAMA DE PÓS-GRADUAÇÃO EM PSICOLOGIA

Lydiane Bocamino

"Meu filho nasceu em casa": compreendendo a experiência de mulheres que optaram pelo parto domiciliar planejado

RIBEIRÃO PRETO

2020 



\section{Lydiane Bocamino}

\section{"Meu filho nasceu em casa": compreendendo a experiência de mulheres que optaram pelo parto domiciliar planejado}

Versão corrigida

Dissertação apresentada à Faculdade de Filosofia Ciências e Letras de Ribeirão Preto da Universidade de São Paulo, como parte das exigências para obtenção do título de Mestre em Ciências. Área de concentração: Psicologia em Saúde e Desenvolvimento.

Orientadora: Prof ${ }^{\mathrm{a}} \operatorname{Dr}^{\mathrm{a}}$ Carmen Lúcia Cardoso

\section{RIBEIRÃO PRETO}


Autorizo a reprodução e divulgação total ou parcial deste trabalho, por qualquer meio convencional ou eletrônico, para fins de estudo e pesquisa, desde que citada a fonte.

Bocamino, Lydiane

"Meu filho nasceu em casa": compreendendo a experiência de mulheres que optaram pelo parto domiciliar planejado. Ribeirão Preto, SP, 2020.

129 p. : il. ; $30 \mathrm{~cm}$

Dissertação de Mestrado, apresentada à Faculdade de Filosofia, Ciências e Letras de Ribeirão Preto da Universidade de São Paulo. Área de concentração: Psicologia em Saúde e Desenvolvimento.

Orientadora: Cardoso, Carmen Lúcia.

1. Parto domiciliar planejado. 2. Parto humanizado. 3. Maternidade. 4. Psicologia da Saúde. 


\section{FOLHA DE APROVACC̃̃O}

Nome: Bocamino, Lydiane

Título: "Meu filho nasceu em casa": compreendendo a experiência de mulheres que optaram pelo parto domiciliar planejado

Dissertação apresentada à Faculdade de Filosofia Ciências

e Letras de Ribeirão Preto da Universidade de São Paulo para obtenção do título de Mestre em Ciências.

Aprovado em:

Banca examinadora

Prof. Dr.:

Instituição: Assinatura:

Prof. Dr.:

Instituição: Assinatura:

Prof. Dr.:

Instituição: Assinatura: 

À todas as mulheres da minha família, em especial, à minha mãe. 



\section{AGRADECIMENTOS}

Agradeço a Deus pela vida e delicadeza de Seu cuidado.

Aos meus pais Lydio (in memorian) e Eva, pelo amor e por apoiarem minhas escolhas.

À minha orientadora, $\operatorname{Prof}^{\mathrm{a}} \operatorname{Dr}^{\mathrm{a}}$ Carmen Lúcia Cardoso, pelo carinho e profissionalismo que me acolheu desde o primeiro encontro. Por seu olhar sensível, por sua dedicação e compreensão nos momentos difíceis.

À Dr ${ }^{\mathrm{a}}$ Licia Barcelos de Souza, por suas contribuições e cafés na cantina.

À cada mulher que participou desse estudo, pela confiança de partilhar sua travessia.

A todos do grupo de pesquisa LaProSUS, pela parceria dos encontros nas sextas de manhã

À Faculdade de Filosofia, Ciência e Letras de Ribeirão Preto, ao Programa de Pósgraduação, aos professores, alunos e funcionários, pela contribuição em minha formação.

À Capes, pelo apoio financeiro.

Aos meus amigos queridos, pelo carinho e compreensão por minhas ausências nesse percurso. 



\section{Travessia}

Estou só...

Estou rodeada de mulheres, daquelas que foram, das que estão aqui e daquelas que virão.

Estou inteira, estou cindida.

A dor rompe meu corpo, um corpo que abriga dois corações.

É chegado o momento da travessia.

Aquele que está para chegar, já está aqui há várias luas.

Me chamam de louca, mas a loucura não me traduz!

Sou solidão, sou muitas, sou dois.

Sou dor, pranto e riso.

Sou bicho, sou humana e divina.

Sou filha, sou mãe, sou nome de flor, sou luz.

Sou medo e coragem.

Sou tudo aquilo que planejei e sou o desconhecido.

Sou escolha, sou segredo, sou controle, sou idealização, sou poder!

Olho a minha volta e reconheço meu ninho, feito com os gravetos que eu mesma escolhi.

Olho para mim e não me reconheço.

Aqui tem meu cheiro, tem aquele que fez essa escolha comigo.

E aqui estão elas, junto de mim.

O relógio ritmado parece parar.

Aquele que espero vai atravessar a água e o fogo.

A boca grita, o mundo se cala e o amor transborda.

Agora tenho um coração que bate fora de mim.

\section{Lydiane Bocamino}





\section{RESUMO}

Bocamino, L. (2020). "Meu filho nasceu em casa": compreendendo a experiência de mulheres que optaram pelo parto domiciliar planejado. Dissertação de Mestrado, Faculdade de Filosofia, Ciências e Letras de Ribeirão Preto, Universidade de São Paulo, Ribeirão Preto.

Atualmente tem aumentado o número de mulheres que estão optando pelo parto domiciliar planejado e essa escolha tem provocado muitos questionamentos e impõe a revisão de práticas e de sentidos tradicionalmente encontrados nesse campo. Assim, o presente estudo objetivou compreender a experiência de mulheres que optaram pelo parto domiciliar planejado. Está ancorado numa abordagem qualitativa de pesquisa, sendo utilizada a Análise de Conteúdo Temática e como instrumentos, a entrevista aberta e um diário de campo. Participaram do estudo 17 mulheres que vivenciaram o trabalho de parto e parto em domicílio e adotou-se o critério de saturação. A análise do corpus possibilitou a construção de três categorias, a saber: 1) Escolha pelo parto domiciliar planejado - que aborda os principais motivos, pelos quais, as participantes optaram por realizar o parto domiciliar; 2) Família e o processo do parto domiciliar planejado - que refere o posicionamento das participantes em relação aos familiares, sobre a escolha pelo parto domiciliar; 3) Sentidos do parto domiciliar planejado - que abarca os múltiplos sentidos sobre o parto domiciliar planejado e foi dividida em três subcategorias, a saber: Parto controle, Parto romântico e idealizado, Parto poder. A análise apontou que a escolha pelo parto domiciliar tem sido motivada pela busca do protagonismo da mulher frente a insatisfação com o atendimento hospitalar e as intervenções hospitalares de rotina, assim como o desejo de vivenciar um parto mais natural. Compartilhar com as famílias a decisão pelo parto domiciliar foi um processo complexo e gerador de angústias. Algumas Participantes optaram por não revelar tal escolha, tendo em vista os receios de serem influenciadas com os medos e julgamentos dos familiares e ainda, como uma forma de preservar os vínculos familiares. As participantes que compartilharam sua escolha, o fizeram no sentido de comunicar uma decisão já firmada. Em relação aos Sentidos do parto domiciliar planejado, a subcategoria Parto controle refere o desejo ou necessidade de controle da mulher durante o processo do parto, atrelado às responsabilidades que esse tipo de parto exige e ainda, como uma forma de minimizar seus medos e angústias. O Parto romântico descreve a experiência de idealização do parto domiciliar, a partir da influência das mídias sociais. O Parto poder aborda a questão dos enfrentamentos do processo do parto domiciliar planejado, com suas especificidades, incluindo passar pela dor do parto sem analgesia, levando a um empoderamento pessoal que ultrapassa o momento do parto. Compreender a singularidade da experiência das participantes revelou as dificuldades vivenciadas no processo do parto domiciliar planejado, permeadas por medos, angústias, sofrimentos, mas também pela descoberta de recursos psicossociais para o enfrentamento de questões relacionadas a maternidade, vínculos familiares e feminilidade. Nesse contexto, embora o estudo tenha privilegiado as experiências do parto domiciliar planejado, as contribuições podem se estender para os processos de parto na rede hospitalar, uma vez que a melhor compreensão das experiências das parturientes pode contribuir para a assistência de humanização ao parto e nascimento.

Palavras-chave: Parto domiciliar planejado. Parto humanizado. Maternidade. Psicologia da Saúde. 



\begin{abstract}
Bocamino, L. (2020). "My son was born at home”: understanding the experience of women that choosed the planned home labor. Masters dissertation, Filosophy, Sciences and Languages College of Ribeirão Preto, São Paulo University, Ribeirão Preto.
\end{abstract}

Lately it has increased the number of women choosing the planned home labor and this choice has provoked many questions and this imposes the revision of practises and meanings that are traditionallt found in this field. So, the presente study aimed to understand women experience that choosed the planned home labor. This research is anchored in a qualitative approach, using the Thematic Content Analysis, having as instruments the opening interwiew and a field journal. Seventeen women, who experienced the labor and home labor, has participated in the study and the saturation criterion was adopted. The corpus analysis made the construction of three categories possible, namely: 1) The planned home labor choice - this approaches the mainly motives by which the participants choosed to perform the home labor; 2) Family and the process of planned home labor - this concerns to the participants position in relation to Family members, about home labor choice; 3) Meanings of planned home labor - this embraces the multiple meanings about planned home labor and it was splitted in three subcategories, namely: Labor Control, Romantic and Idealized Labor, and Powered Labor. The analysis has pointed that the choice for home labor has been motivated by the search of woman protagonism facing dissatifaction with hospital care and the hospital rotine intervations, as well as the desire of experience a more natural labor. Share with the families the decision for home labor was a complex process and a anguish generator. Some of the participants choosed not to reveal such a choice, in view of the apprehensions of being influenced by the fears and judgements of Family members and, still, as a way of preserve the Family bonds. The participants that shared their choice have done this in the meaning of comunicate a decision already made. Concerning to the Meanings of planned home labor, the subcategory Labor Control refers to the desire or necessity of woman control during the labor process, attached to the responsabilities that this kind of labor demands and, still, as a way of minimize their fears and anguishes. The Romantic Labor describes the idealization experience of home labor, as from the social media experience. The Powered Labor approaches the issue of coping with the planned home labor process, with its specifics, including go through pain without analgesia, taking them to a personal empowerment that surpasses the labor moment. Understand the singularity of the participants experience has showed the difficulties experienced in the planned home labor process, but also by psyshosocial resource discovery for coping with issues related to maternity, family bonds, and femininity. In this sense, although the study has privileged the planned home labor experiences, the contribution can be extended to the labor processes in the hospital network, since the best comprehension of the participants experiences can contribute to the humanization assistance at labor and at birth.

Keywords: Planned home labor. Humanized labor. Maternity. Health Psychology. 



\section{SUMÁRIO}

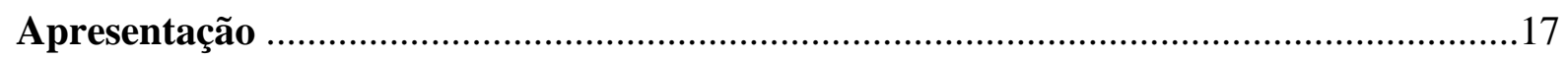

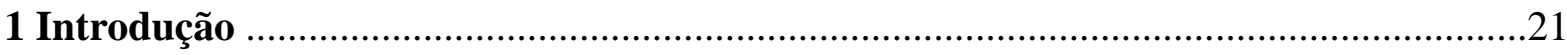

1.1 Parto e nascimento: o modelo de atenção obstétrica no Brasil........................................23

1.2 Humanização do parto e do nascimento ..........................................................................27

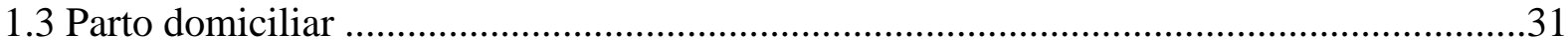

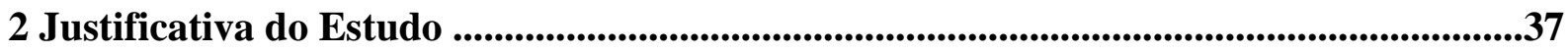

3 Objetivos...........................................................................................................................................41

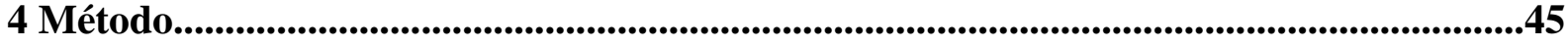

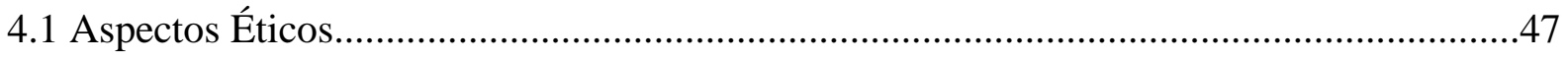

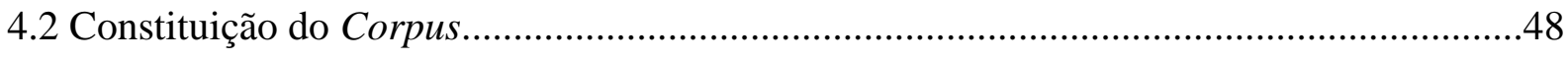

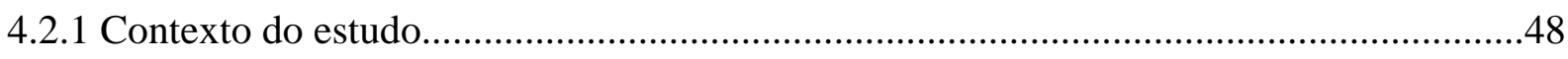

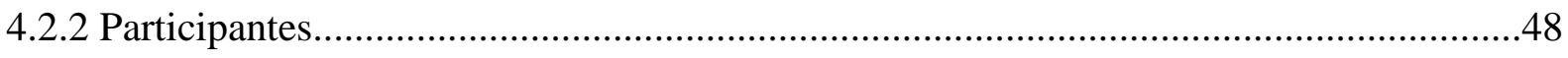

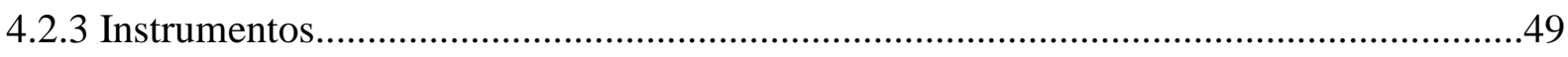

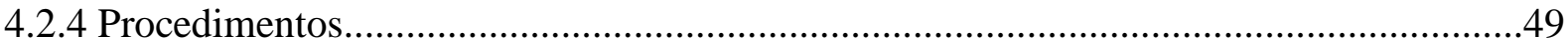

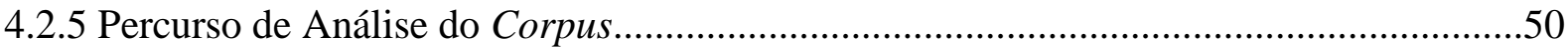

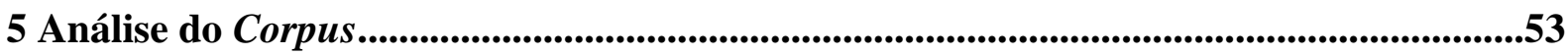

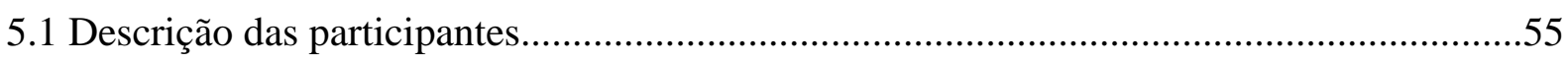

5.2 Categorias Temáticas a partir da análise das entrevistas realizadas................................60

5.2.1 Escolha pelo parto domiciliar planejado..................................................................61

5.2.2 Família e o processo do parto domiciliar planejado.......................................................69

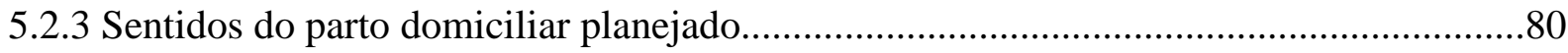

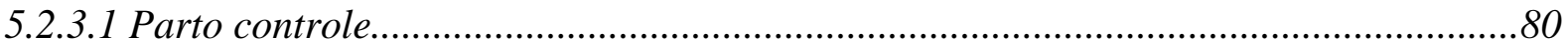

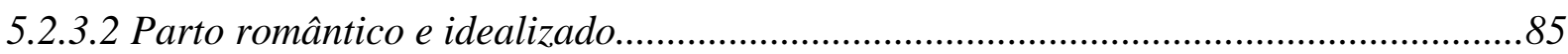

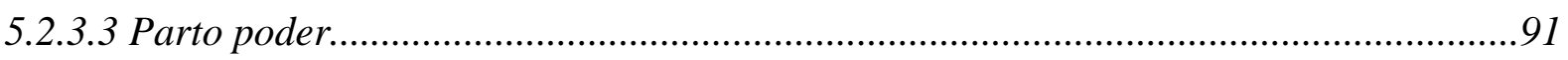

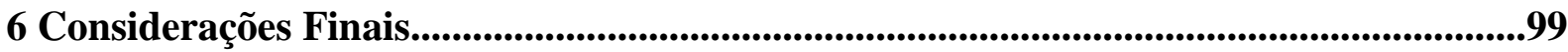


Referências...

Apêndices.

Apêndice A - Termo de Consentimento Livre e Esclarecido.

Apêndice B - Roteiro de entrevistas.

Apêndice C - Quadro A

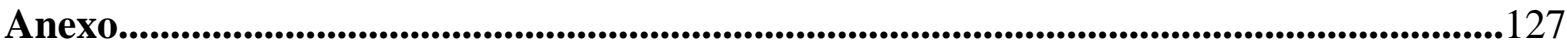

Anexo A - Parecer Consubstanciado do Comitê de Ética em Pesquisa da FFCLRP-USP ..129 
APRESENTAÇÃO 



\section{APRESENTACÃO}

Meu interesse científico pelo desenvolvimento infantil e parentalidade começou em 1996, em minha primeira graduação em Artes Plásticas, quando desenvolvi o projeto “O desenho infantil em crianças de dois a quatro anos: a fase das garatujas", como bolsista do programa de Iniciação Científica PIBIC-CNPq na Universidade Federal de Uberlândia/MG. Este estudo teve como objetivo investigar o processo de desenvolvimento do grafismo infantil de crianças de dois a quatro anos. Para maior aprofundamento e dando continuidade a essa pesquisa, realizei outro trabalho intitulado: "A figura humana e a construção de conhecimento no desenho infantil", um estudo de caso com quatro meninas entre dois a quatro anos, que objetivou analisar o processo de desenvolvimento do grafismo infantil enquanto construção de conhecimento na criança. Nessa época as questões sobre parentalidade já me inquietavam e como parte final do estudo realizei uma entrevista semi-estruturada e individual com as mães das meninas participantes da pesquisa, apresentando também os desenhos de todas as crianças. Dessa forma, pude compreender como as mães concebiam o processo de desenvolvimento e criação dos desenhos. Vale ressaltar que todas as mães reconheceram os desenhos de suas filhas. Esses dados me fizeram refletir sobre o vínculo entre pais e filhos.

Em 2009, já no curso de Psicologia, realizei um estágio na Unimed de São José do Rio Preto/SP, no Programa "Beabá Bebê”, onde havia a participação de grupos de gestantes e grupo pós-parto; foi um período que considerei importante para minhas futuras escolhas acadêmicas. Nesse mesmo ano, iniciei o curso "Clínica de Bebês" e em seguida, um grupo de estudos com a mesma temática. Em julho de 2010 comecei a desenvolver o projeto "A formação e o fortalecimento do vínculo mãe-pai-bebê: um olhar psicanalítico na maternidade", como bolsista do Programa de Iniciação Científica da Universidade PaulistaUNIP. Esse trabalho teve o objetivo de investigar os fatores que contribuem e dificultam a formação e o fortalecimento do vínculo mãe-pai-bebê durante o parto. Contudo, por razões pessoais, mudei para Salvador/BA e o estudo foi desenvolvido parcialmente. Em 2012 realizei outra pesquisa intitulada "A prática clínica com crianças: um olhar psicanalítico sobre o brincar”, no Programa de Iniciação Científica do Centro Universitário Estácio da Bahia.

Durante toda a graduação e até os dias atuais, tenho participado de cursos e eventos científicos, em sua maioria, voltados para os estudos sobre a parentalidade. Em 2013 participei de uma formação no Grupo de Apoio a Maternidade Ativa - GAMA, em São Paulo/SP, para atuar como "Educadora Perinatal”. Essa formação teve como objetivo oferecer subsídios práticos e teóricos para a preparação de casais para o parto e pós-parto, com a 
perspectiva de empoderamento e obtenção de uma experiência de parto positiva e humanizada. Este curso foi fundamental para estimular reflexões e questionamentos sobre a humanização do parto, nascimento e o parto domiciliar planejado. Desde então, participo de grupos virtuais e presenciais que estudam, discutem e apoiam tais temas.

Em 2015 entrei em contato com a professora Carmen Lúcia Cardoso do departamento de Psicologia da Faculdade de Filosofia, Ciências e Letras de Ribeirão Preto da Universidade de São Paulo para discutir a possibilidade de orientação para o mestrado, com o intuito de enriquecer os conhecimentos adquiridos e aprimorar o campo da investigação científica. Assim, comecei a participar do grupo de pesquisa coordenado por ela e a partir desse contexto, foi sendo delineado o projeto de pesquisa que deu origem ao presente estudo. 
INTRODUÇÃO 



\section{INTRODUCÃ̃O}

\subsection{Parto e nascimento: o modelo de atenção obstétrica no Brasil}

Desde as mais antigas civilizações, os partos naturais eram comuns em que as mulheres de comunidades nômades, guiadas por seus instintos, se isolavam para parir. A assistência ao parto se deu quando as próprias mulheres começaram a ajudar umas as outras no nascimento de seus filhos. Contudo, o parto era um evento natural, íntimo, compartilhado entre mulheres e alguns familiares. Nesse contexto, as mulheres que realizavam os partos, conhecidas como parteiras, tinham um vínculo afetivo com as gestantes, uma vez que acompanhavam toda gestação e puerpério e eram consultadas sobre os cuidados com o corpo e as doenças venéreas (Cavaler, Castro, Figueiredo \& Araújo, 2018).

No decorrer do século XX e com o avanço da biomedicina, os cuidados com a maternidade sofreram mudanças significativas. $O$ parto que era um evento domiciliar, privado e realizado por parteiras tradicionais foi para o ambiente hospitalar, centralizado aos cuidados médicos e dependente de intervenções tecnológicas. (Riscado, Jannotti \& Barboza, 2016; Nakano, Bonan \& Teixeira, 2016). Segundo Odent (2016), na fase de transição do parto domiciliar para o hospitalar, "a maioria das mulheres ainda paria por si só" (p. 32), pois as infusões intravenosas, como a ocitocina, por exemplo, ainda não eram comuns. $O$ autor refere que nessa época não havia especialista em anestesia obstétrica e a cesárea era uma intervenção pouco realizada, reservada para emergências. Cavaler et al. (2018), acrescentam que o início da transição do parto em casa para o hospital foi acompanhado por mudanças nos hábitos das mulheres que passaram a frequentar consultórios de obstetras e pediatras, fazer maior uso de medicamentos, consumo de produtos de higiene e alimentação infantil industrializada.

De acordo com Nakano, Bonan e Teixeira (2016), o desenvolvimento científico da obstetrícia e a institucionalização do parto foram muito importantes para a gestação de alto risco, pois a cesárea contribuiu para a redução de taxas de mortalidade materna e neonatal. Por outro lado, segundo o Ministério da Saúde (2010), a institucionalização do parto trouxe a medicalização e a perda da autonomia da mulher como protagonista do processo de parir.

Atualmente, a Organização Mundial da Saúde (OMS, 2015) recomenda que no máximo $15 \%$ dos partos realizados sejam cesáreas, pois um alto índice desse tipo de parto traz 
riscos tanto para a mãe quanto para o bebê. Contudo, a pesquisa "Nascer no Brasill", maior estudo sobre parto e nascimento já realizado no país revelou que a prevalência de cesáreas no Brasil é a mais alta do mundo (Leal \& Gama, 2014). De acordo com os resultados, 52\% dos partos realizados são cesarianas, sendo que desses, $46 \%$ no setor público e $88 \%$ no setor privado. O estudo aponta ainda, que não há indicação clínica para um número tão elevado de cesáreas e que as mulheres são submetidas a uma cirurgia sem indicação obstétrica adequada, expostas juntamente com seus bebês, à maiores riscos de morbidade e mortalidade (Torres et al., 2014). Segundo Leal et al. (2014a) não tem sido uma "experiência natural" nascer no Brasil. No setor público o parto vaginal frequentemente ocorre com muitas intervenções e dor e no setor privado as cesarianas, que são quase sempre agendadas, chegam como uma opção para diminuir esse sofrimento.

Segundo Souza e Pileggi-Castro (2014), as altas taxas de cesáreas no Brasil indicam o grau de hipermedicalização da maternidade no país. Esse é um problema complexo e multifatorial, que inclui o protagonismo dos obstetras, conveniência das cesáreas para muitos profissionais da saúde e a percepção da população de que a cesárea é uma via de parto melhor que a do parto vaginal. Gama et al. (2014) acrescentam que nas adolescentes, as cesarianas também foram frequentes (42\%), o que representa um dado preocupante, pois são mulheres que iniciam cedo a vida reprodutiva, tendem a ter um número maior de filhos e assim ficam expostas a maiores riscos em futuras gestações.

De acordo com Leal e Gama (2014), entre as mulheres que tiveram parto vaginal, predominou um modelo de atenção medicalizada, o que pode causar dor e sofrimentos desnecessários. A maioria delas foi submetida a excessivas intervenções, ficou restrita ao leito sem caminhar, sem se alimentar durante o trabalho de parto, usou medicação para acelerar as contrações, fez episiotomia, teve seu bebê deitada de costas e algumas vezes com alguém empurrando sua barriga (Manobra de Kristeller); procedimentos não recomendados como rotina pela OMS. Apenas 5\% das entrevistadas vivenciaram um parto sem essas intervenções. Nesse contexto, Aquino (2014) aponta que o modelo de assistência ao parto é caracterizado pela prevalência de recursos médicos sobre as relações humanas, em que há a ideia de

\footnotetext{
${ }^{1}$ Pesquisa coordenada pela FioCruz em parceria com diversas instituições científicas e divulgada em maio de 2014. Foram pesquisadas 23.984 mulheres que tiveram partos em hospitais públicos, privados e mistos, com o objetivo de se conhecer a atenção ao pré-natal, parto, nascimento e puerpério (Vasconcelos et al., 2014). A pesquisa "Nascer no Brasil" foi referência para os dados apresentados no tópico 1.1 do presente estudo. Vale ressaltar que em 2019 foi iniciada uma nova etapa da Pesquisa "Nascer no Brasil", com a finalidade de investigar se houve mudanças na atenção obstétrica no país.
} 
passividade das mulheres que são imobilizadas, enquanto sofrem intervenções desnecessárias por profissionais desconhecidos, para abreviar o tempo do parto. Leal et al. (2014a) acrescentam que o uso excessivo de intervenções na atenção ao parto não encontra respaldo em estudos internacionais. As práticas recomendadas no trabalho de parto de gestantes de baixo risco, como alimentação, mobilidade, uso de métodos não farmacológicos para alívio da dor e plano de parto, foram pouco utilizadas no serviço de saúde (Cecatti, 2014).

Ainda referente às práticas no parto, a pesquisa "Nascer no Brasil" revelou que 75\% das mulheres tiveram um acompanhante em algum momento do parto (Diniz et al., 2014). A presença de um acompanhante no parto traz benefícios e evita problemas, pois a gestante fica mais tranquila e segura, o que contribui para a redução do tempo de parto e o acompanhante pode ajudar nos cuidados básicos com o recém-nascido. A presença do companheiro no parto pode ainda, melhorar o vínculo afetivo entre o casal. Dessa forma, com o objetivo de melhorar a qualidade de atendimento às gestantes e humanizar os partos, foi criada a Lei do acompanhante no parto, em que as mulheres atendidas pelo Sistema Único de Saúde (SUS) têm o direito de escolher alguém de sua confiança para lhes acompanhar no parto e pós-parto (Lei n. $\left.{ }^{\circ} 11.108,2005\right)$. Entretanto, apenas $20 \%$ das pesquisadas tiveram um acompanhante durante todo período de internação, sendo privilégio das mulheres brancas, usuárias do setor privado, com maior escolaridade e renda e que tiveram cesariana (d'Orsi et al., 2014). Nesse sentido, Aquino (2014) refere que apesar dos dados positivos do estudo, tanto no setor público quanto no privado, o direito à informação não é garantido e não se respeita a autonomia das mulheres, ferindo a integridade corporal e o direito ao acompanhante previsto por lei.

De acordo com Domingues et al., (2014), outro dado significativo da pesquisa apontou que no início da gestação quase $70 \%$ das brasileiras desejavam um parto vaginal, contudo, apenas $15 \%$ tiveram apoio em sua escolha. No decorrer da gestação houve uma mudança na decisão pelo tipo de parto, sem explicação pela ocorrência de problemas ou complicações. Esses dados sugerem que há uma indução para a aceitação da cesárea durante o pré-natal. As mulheres que mantiveram o desejo pelo parto vaginal até o final da gestação, apresentaram menor número de cesáreas (20\%). Entre as que já haviam passado por uma cesárea anterior, apenas $15 \%$ tiveram um parto vaginal na gestação atual. Segundo Leal et al. (2014b), isso contraria as evidências científicas que mostram partos vaginais com êxito após uma cesariana. Contudo, no Brasil, acredita-se que quando o primeiro parto é uma cesárea todos os outros também deverão ser. Esses dados reforçam a necessidade de orientar e apoiar a mulher no parto vaginal, evitando a primeira cesariana. 
Sobre as mulheres que optaram desde o início pela cesariana, um terço apontou o medo da dor do parto como principal justificativa. As mulheres do setor privado que optaram pela cesárea como primeira escolha, podem não estar sendo informadas das vantagens e desvantagens dessa via de parto e assim, não estão conscientes do risco da prematuridade e suas consequências. Em relação aos bebês prematuros (antes de 37 semanas), a proporção foi de $11,3 \%$ dos nascimentos. Comparados aos dados populacionais encontrados na Inglaterra e País de Gales, a proporção no Brasil é 55\% maior. Outro ponto preocupante da pesquisa "Nascer no Brasil" informa que 35\% dos bebês nasceram entre 37 e 38 semanas. Esse dado, em parte, deve-se ao número elevado de cesáreas agendadas antes do trabalho de parto, o que pode provocar internações em UTI neonatal, suporte ventilatório para respirar e maior risco de morbidade e mortalidade. As cesáreas agendadas sem indicação e com ausência de mecanismos fisiológicos de adaptação ao nascimento podem causar prematuridade e riscos para a adaptação dos bebês (Chaves, 2014).

Sobre os cuidados com os recém-nascidos saudáveis e a termo, Moreira et al. (2014) relatam que as práticas inadequadas continuam sendo usadas, como aspiração de vias aéreas superiores, aspiração gástrica, uso de oxigênio inalatório, incubadora e a separação precoce da mãe e do bebê, que ocorre com mais frequência nas cesáreas do que nos partos vaginais.

Leal e Gama (2014) referem que o Brasil tem uma elevada cobertura de assistência pré-natal e em 2010 o número foi superior a 98\%, ainda assim, as taxas de mortalidade materna e perinatal são altas, o que sugere problemas na qualidade de atenção nessas áreas. A mortalidade materna no Brasil decresceu muito nos últimos anos, contudo, ainda é considerada alta, chegando a ser três a quatro vezes maior do que nos países mais desenvolvidos. Parte dos riscos associados à maternidade são socialmente determinados, mas os fatores ambientais, biológicos e de acesso e qualidade no uso de tecnologias em saúde também devem ser levados em consideração. A utilização dessas tecnologias favorece a redução da morbimortalidade materna, entretanto, o uso excessivo e desnecessário de medicalização e tecnologias de saúde na assistência à gestação e parto representam riscos para as mães e os bebês (Silva et al., 2014). Lansky et al. (2014) acrescentam que a mortalidade neonatal está associada ao baixo peso ao nascer, risco gestacional e inadequação da atenção ao pré-natal e ao parto.

A pesquisa "Nascer no Brasil" concluiu que as mulheres e seus bebês são expostos aos riscos de efeitos adversos no parto e no nascimento de forma desnecessária. As mulheres de nível social mais elevado sofrem mais intervenções obstétricas, incluindo as cesáreas e seus bebês nascem antes de 39 semanas gestacionais. As mais pobres, que utilizam o serviço 
público, são submetidas a partos dolorosos e com administração de remédios, com piores indicadores perinatais e condições de saúde (Leal et al., 2014a). De acordo com Downe (2014) esses resultados não são tão surpreendentes, levando-se em conta o aumento mundial das intervenções de rotina no trabalho de parto. Esses dados sugerem a necessidade de mudanças na assistência ao parto, pois a longo prazo, podem se estabelecer padrões de morbidade materna e neonatal decorrentes das intervenções desnecessárias (Riesco, 2014). Nesse contexto, Serruya (2014) ressalta que muitas mulheres estão insatisfeitas com a atenção recebida e esperam que mudanças possam acontecer nesse cenário.

Segundo Gomes (2014) o momento atual é fértil e promissor quanto à possibilidade de revisão de conceitos, valores e práticas assistenciais; pois os estudos sobre a inadequação do cuidado e violência institucional nas maternidades, entre outros, estão fortalecendo movimentos sociais e provocando discussões no Ministério Público e Legislativo.

\subsection{Humanização do parto e do nascimento}

Nesse contexto de mudanças na atenção obstétrica, vários são os incentivos e campanhas governamentais que orientam e apoiam a humanização do parto e nascimento, a saber: Programa Humanização do Parto: humanização ao pré-natal e nascimento - PHPN (Ministério da Saúde, 2002) visa assegurar a melhoria do acesso, da cobertura e da qualidade do acompanhamento pré-natal, da assistência ao parto e puerpério à gestante e ao recémnascido; Política Nacional de Atenção Integral à Saúde da Mulher - PNAISM (Ministério da Saúde, 2004) promove a integridade e saúde da mulher no campo dos direitos sexuais e reprodutivos, com ênfase na melhoria da atenção obstétrica, no planejamento familiar, atenção ao abortamento inseguro e combate a violência doméstica e sexual, assim como a prevenção e tratamento de HIV/Aids e câncer ginecológico; Lei do acompanhante durante o trabalho de parto, parto e pós-parto (Lei $\mathrm{n}^{\circ} .11 .108,2005$ ) em que o SUS e redes conveniadas ficam obrigados a permitir a presença de um acompanhante durante todo trabalho de parto, parto e pós-parto, a escolha da parturiente; Rede Cegonha (Ministério da Saúde, 2011) visa implementar cuidados para assegurar às mulheres, o direito ao planejamento reprodutivo e a atenção humanizada à gravidez, ao parto e puerpério, e ao crescimento e desenvolvimento saudável do bebê até dois anos; criação do Centro de Parto Normal (Ministério da Saúde, 2015) em conformidade com a Rede Cegonha, tem o objetivo de acolher a mãe e o recémnascido com atenção humanizada ao parto e nascimento, fundamentada no protagonismo da mulher; Lei do Parto Humanizado para o Estado de São Paulo (Lei nº 15.759, 2015) que 
garante à gestante receber assistência humanizada durante o parto, contando com a elaboração de um plano individual de parto, com mínima interferência dos profissionais da saúde, presença de um acompanhante a sua escolha, informação e oportunidade de escolha por métodos menos invasivos para a mãe e para o bebê, caso não haja riscos para ambos; Protocolo Clínico de Diretrizes Terapêuticas para Cesarianas (Ministério da Saúde, 2016a) tem o objetivo de orientar profissionais e a população sobre as indicações clínicas para as cesarianas e os cuidados com o recém-nascido, diminuindo assim, o número de cirurgias desnecessárias e evitando riscos para a mãe e o bebê; Diretrizes Nacionais de Assistência ao Parto Normal (Ministério da Saúde, 2017) visa contribuir com a melhoria da assistência obstétrica no país, promovendo mudanças na prática clínica da assistência ao parto normal, como a diminuição da variabilidade de condutas entre profissionais no processo da assistência ao parto, redução de intervenções desnecessárias e seus agravos, difusão de práticas baseadas em evidências e recomendação de determinadas práticas sem no entanto, substituir o julgamento individual do profissional, da parturiente e dos pais em relação à criança, no processo de decisão no momento de cuidados individuais.

Outra iniciativa importante é o projeto "Parto Adequado" que está sendo desenvolvido pela Agência Nacional de Saúde Suplementar (ANS, 2015) em parceria com o Hospital Albert Einstein, o Institute for Healthcare Improvement (IHI) e com o apoio do Ministério da Saúde. Este projeto tem como objetivo mudar o modelo de atenção ao parto e nascimento, promovendo o parto normal e reduzindo o número de cesarianas desnecessárias na saúde suplementar. Vale destacar também, os documentários brasileiros "O Renascimento do Parto", "O Renascimento do Parto 2" e "O Renascimento do Parto 3" (Chauvet, 2013, 2015 e 2018), que tiveram grande visibilidade e repercussão e desde então, vem gerando reflexões e discussões sobre o modelo obstétrico no país, a humanização do parto e nascimento e o parto domiciliar planejado. Segundo Diniz (2014) o documentário revela que o parto é um fenômeno biopsicossocial e espiritual e não deve ser reduzido apenas às dimensões biológicas, empobrecendo a experiência e diminuindo sua segurança e efetividade.

Ainda sobre os incentivos e campanhas que apoiam a humanização do parto e nascimento, a OMS e o Serviço Nacional de Saúde (SNS) emitiram em 2018, novas diretrizes para o atendimento às gestantes, com o objetivo de reduzir intervenções médicas desnecessárias e recomendando que as equipes médica e de enfermagem não interfiram no trabalho de parto com o intuito de acelerá-lo, a menos que existam riscos e complicações para a mãe e para o bebê. O documento possui 56 recomendações sobre o trabalho de parto e pósparto imediato, incluindo o direito de acompanhante à escolha da gestante, respeito pela 
autonomia da mulher na gestão da dor e posições escolhidas por ela durante o parto e o respeito pela escolha de um parto natural e sem intervenções (World Health Organization, 2018; Serviço Nacional de Saúde, 2018).

Nesse cenário e na contramão desses tempos de tecnologias médicas tão sofisticadas, surge no país grupos de mulheres favoráveis ao parto humanizado, desprovido de intervenções médicas e farmacológicas de rotina. Por outro lado, surgem também críticas de profissionais de saúde que entendem esse desejo das mulheres, como insanidade e um retrocesso cultural (Carneiro, 2013). Os modelos de assistência ao parto e a realização de cesáreas e partos vaginais são questões que vêm sendo discutidas no Brasil desde a década de 1980. Há uma complexidade de fatores diante da escolha pelo tipo de parto e nesse contexto, a assistência recebida pelas gestantes tem levantado vários questionamentos que envolvem desde a qualidade de atenção obstétrica até o significado de parturição para as mulheres (Pereira, Fonseca, Costa Pereira, Gonçalvez \& Mafra, 2018).

De acordo com Russo, Nucci, Silva e Chazan (2019) o parto humanizado vem sendo objeto de muitos estudos e dessa maneira, tem se transformado num importante núcleo de modificações sobre a maneira como as mulheres têm tido seus filhos; configurando um movimento social, especialmente nas redes sociais, questionando o parto hospitalar tradicional. Segundo as autoras, esse movimento propõe mudanças sobre a assistência e a medicalização do parto, incentivando práticas mais adequadas à fisiologia do parto e vem se difundido em grande parte do país através de ações e programas de saúde. Nesse sentido, Tempesta e Carneiro (2018) referem que esse cenário foi adquirindo pauta de direitos humanos, à medida que a assistência institucional recebida pelas mulheres durante o parto foi considerada por elas, como violenta e recentemente nomeada como "violência obstétrica".

Segundo Mattos (2018) o termo "humanizado" refere-se a um atendimento de qualidade associado ao avanço tecnológico que valoriza a troca de saberes e que inclui os pacientes e seus familiares. Nesse contexto, no processo de humanização do parto e nascimento, a relação da equipe com a mulher é fundamental. Para isso, é importante que haja comunicação e confiança nessa relação e que os profissionais de saúde respeitem a autonomia da gestante e a fisiologia do parto, promovendo apoio físico e emocional à parturiente e sua família. O autor acrescenta que, além das necessidades biológicas e fisiológicas, as necessidades psicológicas da parturiente também precisam ser reconhecidas, considerando que os valores são individuais e culturais.

Sobre o parto humanizado, Odent $(2000,2002)$ esclarece que durante o trabalho de parto, a parte mais ativa do corpo da mulher é também a mais primitiva do cérebro, que 
funciona como uma glândula, liberando hormônios. Quando surgem inibições, elas se originam na parte do cérebro altamente desenvolvida em humanos - o neocórtex. A redução da atividade cortical é o aspecto mais importante da fisiologia do parto. Assim, qualquer estimulação do neocórtex materno, como rodeá-la de luzes, muito barulho, fazê-la sentir-se insegura ou outros modos de estimular uma liberação de adrenalina, tende a inibir o processo natural de parto.

Em um trabalho de parto humanizado, muitas mulheres passam por mudanças em seu nível de consciência, ficam com um olhar distante, esquecem convenções sociais, perdem autoconsciência e autocontrole, mas não se encontram desvalidas ou perdidas. Elas agem de forma deliberada e espontânea buscando posições mais adequadas e eficientes fisiologicamente (Odent, 2002). Nessa perspectiva, a "partolândia" é uma expressão muito usada entre as adeptas do parto humanizado. Refere-se a um estado de consciência alterado durante o trabalho de parto, momento de interrupção do neocórtex em que a mulher retoma seu estágio mais arcaico, é uma reação hormonal própria do parto, onde muita ocitocina e serotonina são liberadas, desde que a mulher não se sinta ameaçada e libere adrenalina. Dessa forma, parir vai além de ato fisiológico, é uma experiência única, pessoal, sexual, espiritual, social e cultural (Carneiro, 2013).

Balaskas (2003) aponta que, se a mulher tiver um desempenho ativo durante o trabalho de parto, não haverá interrupção da fisiologia normal do parto ou interferências com o equilíbrio hormonal e dessa forma, raramente haverá depressão puerperal ou problemas com a amamentação. Segundo a autora, o "Parto Ativo" é instintivo, é uma atitude mental que envolve aceitação e crença na função natural e involuntária do processo de parto. É um modo natural e espontâneo de dar à luz, em que a mulher por sua própria vontade e determinação tem liberdade de escolha para usar seu corpo como desejar e seguir suas solicitações.

Sobre a cena do parto, Carneiro (2013) encontrou representações singulares em seus estudos. Para o médico, a dor do parto pode ser a pior do mundo. A ideia de que parir dói também faz parte do universo feminino. Contudo, a dor no pré-parto é compreendida por algumas mulheres como uma sensação corpórea a ser enfrentada e suportada pela experiência de parir, sentindo tudo o que está envolvido nesse acontecimento. Já no pós-parto, a dor foi descrita pelas mulheres como "a dor que se sente, mas se esquece", como um ritual de passagem, "a dor que não é sofrimento" e por fim "não senti dor, foi prazeroso". A autora concluiu que as adeptas ao parto humanizado não se percebem como "mãezinhas" que sofrem com corpos frágeis e vítimas da própria anatomia, mas procuram estabelecer outro diálogo com a maternidade. Nesse sentido, Gutman (2013) refere que parir é passar de um estágio 
para outro, um rompimento espiritual e como tal, provoca dor, entretanto o parto não é uma enfermidade para ser curada.

Vale ressaltar que nem todo parto normal configura-se em um parto humanizado. Velho, Santos, Brüggemann e Camargo (2012) apontam que a vivência do parto normal institucionalizado é percebida por muitas mulheres, como um processo doloroso, acrescido de procedimentos dolorosos e inesperados, não respeitando seu protagonismo e reproduzindo o modelo de medicalização hospitalar. Por outro lado, algumas mulheres acreditam que alguns procedimentos, ainda que contraindicados, como a episiotomia e a Manobra de Kristeller, são necessários durante o parto. Muitas vezes o parto normal não é percebido como um evento natural e a hospitalização passa a ser uma vivência indispensável. Dessa maneira, segundo os autores, o hospital é o melhor lugar para o parto por ter uma assistência técnica especializada e ao mesmo tempo, o pior lugar, devido a assistência desqualificada e a perda de autonomia da mulher.

De acordo com Busanello et al. (2011), os princípios de humanização na assistência obstétrica e neonatal propostas pelo Ministério da Saúde para humanização do pré-natal e nascimento, ainda enfrentam muitas resistências nos centros obstétricos no Brasil. Nessa perspectiva, Martins, Almeida e Mattos (2012) defendem que as ações de humanização ao trabalho de parto devem atender as necessidades da mulher e de sua família, além dos aspectos biológicos, abarcando as circunstâncias sociais, éticas, educativas e psicológicas presentes nas relações humanas. À esse respeito, Odent (2002) compreende que cada mulher traz uma história cultural, familiar e pessoal única, que influencia fortemente o seu trabalho de parto. Segundo Mattos (2018), uma assistência humanizada no parto se configura com a autonomia da mulher diante de suas escolhas e ações, proporcionando a ela, maior segurança durante o parto e os cuidados com o filho. $\mathrm{O}$ autor acrescenta que nesse contexto, a equipe profissional deve atuar como facilitadora para que a mulher seja protagonista do seu processo de parto que é singular.

\subsection{Parto domiciliar}

O parto domiciliar pode ou não ser planejado. Revisitando a história, compreende-se que no Brasil, a maioria dos partos domiciliares não eram planejados ou eram assistidos por parteiras leigas. Até pouco tempo atrás, o parto domiciliar era mais frequente nas regiões pobres e distantes, onde as famílias não tinham acesso aos hospitais e os partos eram feitos por parteiras tradicionais. Apenas nas últimas décadas se configurou o modelo de parto 
domiciliar planejado, realizado a partir da escolha da mulher, com profissionais qualificados e uma assistência prestada na gestação, parto e pós-parto imediato (Feyer, Monticelli, Boehs \& Santos, 2013; Feyer, Monticelli, \& Knobel, 2013; Pompeu, 2019).

Nessa perspectiva, Peppe (2017) refere que no Brasil ainda existem dois contextos distintos de partos domiciliares, a saber: o parto domiciliar realizado por parteiras tradicionais em regiões mais pobres e com poucos recursos e o parto domiciliar planejado, assistido por equipes especializadas em centros urbanos para um público de classe média e alta. Segundo a autora, nesse cenário, o parto domiciliar planejado emerge como um movimento de elite. A esse despeito, o Ministério da Saúde (2012a) esclarece que o parto domiciliar realizado por parteiras tradicionais ainda está presente, principalmente no Norte e Nordeste do Brasil, nas regiões rurais, ribeirinhas, de florestas, indígenas e quilombolas. Estima-se que existam mais de 60 mil parteiras tradicionais em atuação no país. Nesse contexto, Mattos (2018) aponta que o termo parto domiciliar planejado designa partos que são realizados em domicílio, de forma intencional e programado pela mulher e/ou família, juntamente com a equipe que acompanhou a gestante durante o pré-natal de risco habitual. É um tipo de parto que permite maior controle do ambiente pela parturiente e das pessoas envolvidas.

Atualmente, muitas mulheres têm optado por esse tipo de parto, principalmente nos grandes centros urbanos, onde a assistência é feita por profissionais de saúde especializados, particularmente médicos, enfermeiras, obstetrizes e não mais exclusivamente as parteiras tradicionais. A escolha pelo parto domiciliar planejado tem provocado novos comportamentos, valores e sentimentos tanto nas famílias, quanto nos profissionais. Alguns dos fatores apontados pelos casais que fazem essa opção são: o desejo de afastamento do ambiente hospitalar e das cesáreas eletivas, o desejo de vivenciar o nascimento com maior autonomia para a mulher e ainda, proporcionar uma recepção mais aconchegante ao bebê. Outro fator importante é que nesse cenário, o homem tem a oportunidade de se colocar não apenas como acompanhante, mas como sujeito ativo, envolvido no processo de nascer como pai (Feyer, Monticelli, Boehs, et al., 2013; Feyer, Monticelli \& Knobel, 2013).

Segundo Martinez-Molla, Solano e Siles (2013), um parto domiciliar planejado configura-se com o desejo da mulher de parir em casa, reunindo critérios médicos de normalidade, assistido por profissionais qualificados, com equipamentos adequados e com acesso hospitalar, caso necessário. Dessa maneira, o casal precisa conhecer o hospital no qual, caso haja intercorrências, deva ser transferido. A decisão pelo parto em casa deve ser tomada em conjunto, buscando informações e avaliando os riscos para a mãe e o bebê. Sobre a escolha pelo parto domiciliar, Pimenta (2013) refere que ela pode ser influenciada pelas 
histórias de vida de mulheres que já passaram por essa experiência, seja uma familiar, vizinha ou amiga. A história pessoal, familiar e cultural tem uma forte influência no parto. Para Barbosa (2013), crenças de bem estar, escolha do acompanhante, atenção personalizada, atenção materno-infantil e experiências prévias insatisfatórias com o setor de saúde, também são fatores decisivos pela escolha do parto domiciliar. Segundo Feyer, Monticelli e Knobel (2013) escolher o domicílio para o parto é uma mudança que envolve novos comportamentos, valores e sentimentos relacionados à maneira de parir e nascer, valorizando o parto como um rito de passagem que deve ser vivido e experenciado na intimidade do lar.

O desejo de parir, respeitando a fisiologia natural do parto e reduzindo as intervenções desnecessárias, tem mobilizado mulheres em vários lugares do mundo. Gutman (2013) aponta que nos países mais desenvolvidos, as mulheres estão criando modelos livres e autônomos de parir. Na Alemanha, Inglaterra, Holanda, Espanha e Estados Unidos, as mulheres estão cada vez mais, optando por parir em suas casas, com parteiras ou em "casas de nascimento" que se assemelham mais a um lar do que a um hospital. Entretanto, segundo Martinez-Molla et al. (2013) o parto domiciliar planejado, no Brasil gera muitas controvérsias e discussões entre os especialistas, porém, para as gestantes de baixo risco e quando assistido por profissionais capacitados e habilitados, o parto em casa traz grandes benefícios para as mães e seus bebês.

Prates et al. (2018) referem que a insatisfação das mulheres frente a assistência obstétrica vem provocando um movimento de resgate do parto fisiológico, feminino, familiar e social. Dessa forma, elas buscam a experiência de um parto mais prazeroso e sem as intervenções hospitalares de rotina. Assim, segundo as autoras, percebe-se um aumento pela escolha do parto normal e do parto domiciliar planejado. Nesse cenário, Mattos (2018) refere que a assistência ao parto avança para práticas menos intervencionistas, com a retomada de valores que buscam o resgate do modelo histórico do nascimento. Segundo o autor, a escolha pelo parto domiciliar planejado é uma reação à abordagem de parto intra-hospitalar, com processos intervencionistas e tecnológicos que dificultam o empoderamento e protagonismo da mulher. De acordo com Peppe (2017) as mulheres que optam pelo parto domiciliar contam com maior liberdade de escolhas quanto à movimentação, posições e alimentação, têm maior índice de contato imediato pele a pele com o bebê e amamentação na primeira hora de vida, menores taxas de morbidade materna grave e hemorragia pós-parto, remoção manual da placenta e de intervenções como a amniotomia e episiotomia.

Segundo a OMS e o Ministério da Saúde (2010) o domicílio é um lugar adequado e seguro para o parto da gestante de risco habitual, desde que essa seja sua escolha e que tanto 
ela, quanto sua família recebam cuidados seguros no momento do parto. Nesse sentido, Peppe (2017) refere que existem recomendações que precisam ser seguidas para que a mulher possa realizar um parto domiciliar, a saber: mulheres com idade gestacional entre 37 e 42 semanas, com gestação de risco habitual, que sejam atendidas por profissionais qualificados e que tenham um plano emergencial caso necessitem de transferência para o hospital.

Frank e Pelloso (2013) relatam que para uma evolução adequada no trabalho de parto é importante a autonomia, individualidade e a privacidade, condições estas, que a mulher pode encontrar em seu lar, junto as pessoas que a amam. Koettker, Brüggemann e Dufloth (2012) referem que a mulher que opta pelo parto domiciliar participa mais do trabalho de parto, é menos ansiosa e confia mais na fisiologia do corpo do que a que opta pelo parto hospitalar. Mattos (2018) acrescenta que no parto domiciliar, o número de intervenções é restrito e desde que haja um pré-natal adequado e os procedimentos sejam feitos por profissionais qualificados, o risco de complicações fica reduzido.

De acordo com Frank e Pelloso (2013), existem riscos tanto no parto domiciliar quanto no hospitalar e ambos possuem suas indicações. A avaliação de risco deve ser adotada em todo trabalho de parto domiciliar e a qualquer intercorrência deve ser feita a transferência para um hospital. Contudo, a segurança não está voltada apenas ao local, mas também ao tipo de formação profissional dos que assistem ao parto. Sobre os principais motivos de transferência do parto domiciliar para o hospitalar, Koettker et al. (2013) descrevem: a parada da progressão da dilatação do colo uterino e a descida do feto, desproporção céfalo-pélvica, rotura prolongada das membranas e exaustão materna com necessidade de medicação para alívio da dor.

Entretanto, para grande parte da sociedade brasileira, o parto domiciliar ainda representa maior risco de problemas materno e neonatal, inclusive para os profissionais de saúde, visto que o parto hospitalar tornou-se "natural" e parir fora desse ambiente passou a ser considerado anormal ou acidental, associado à falta de assistência em saúde (Lessa, Tyrrell, Alves \& Rodrigues, 2014; Castro, 2015).

Collaço et al. (2018) referem que na contemporaneidade, o parto domiciliar planejado surge como uma possibilidade de reaproximação entre ciência e tradição, habilidade e intuição, estimulando o protagonismo do casal no processo de um parto mais fisiológico e contando com o apoio de uma equipe especializada. Segundo as autoras, no parto domiciliar, o contexto ambiental do processo de gestação, parto e puerpério é importante para a mulher porque refere-se ao espaço físico e sociocultural que contempla a privacidade e 
respeito às crenças e valores do casal. E ainda, pode proporcionar ao casal, a participação de outros familiares e pessoas significativas.

No Brasil não há dados sobre o atendimento ao parto domiciliar planejado, pois o Sistema de Informação sobre Nascido Vivo (SINASC) engloba todos os nascimentos ocorridos fora do hospital, independente de serem ou não planejados e da assistência prestada. Por outro lado, em países mais desenvolvidos, a prevalência de parto domiciliares planejados e assistidos por profissionais qualificados é variável, 11,3\% na Nova Zelândia, 2,8\% na Inglaterra, menos de $1 \%$ na Austrália e 62,7\% na Holanda (Koettker, Bruggemann, Freita, Riesco \& Costa, 2018).

Castro (2015) entrevistou 20 mulheres que optaram por um parto domiciliar planejado, dessas, 19 tinham ensino superior completo e uma incompleto; 19 receberam assistência de profissionais de saúde, como enfermeira obstetra, obstetriz, médico obstetra, pediatra e doula e uma optou por não receber assistência. Esses dados apontam a importância de uma equipe especializada para o parto domiciliar planejado. Nessa perspectiva, Pompeu (2019) esclarece que no país a constituição de equipes especializadas para o parto domiciliar planejado é recente e que ainda não há dados oficiais sobre o número de equipes, quais regiões atuam e como se organizam. Nesse contexto, a falta de dados impede a sistematização de informações sobre o modelo de assistência prestada e a comunicação entre as equipes. A autora ressalta que a comunicação é um instrumento importante, uma vez que pode permitir a divulgação de experiências e assim, qualificar os serviços através de um cuidado em saúde mais seguro para a mãe e para o bebê.

Vale ressaltar que no Brasil, apenas o Hospital Sofia Feldman em Belo Horizonte/MG, disponibiliza assistência e equipe especializada para o parto domiciliar planejado, através do SUS. Considerando que os planos de saúde não cobrem os gastos referentes a esse tipo de parto, infere-se que esse planejamento, que tem um custo significativo, acaba favorecendo mulheres com maior poder socioeconômico. 
JUSTIFICATIVA 


\section{JUSTIFICATIVA}

A pesquisa "Nascer no Brasil" (Vasconcelos et al., 2014) revelou que a prevalência de cesáreas no país é a mais alta do mundo e que apenas $5 \%$ dos partos são naturais e sem intervenções, o que contraria as recomendações da OMS, que preconiza que no máximo 15\% dos partos realizados sejam cesarianas. Outro dado da pesquisa sugere que pode haver uma indução para a aceitação da cesárea durante o pré-natal. O elevado número de cesáreas, a hipermedicalização no parto, o uso de procedimentos desnecessários, a prematuridade nos nascimentos, a mortalidade materna e perinatal, estão colocando em risco as mulheres e seus bebês no parto e nascimento. Dessa maneira, a assistência obstétrica no Brasil tornou-se um problema de saúde pública (Leal \& Gama, 2014; Domingues et al., 2014).

Diante desse cenário, os Governos Federal e Estadual e a iniciativa privada vêm criando campanhas com o objetivo de esclarecer, incentivar e apoiar a humanização do parto e nascimento. Diniz (2014) aponta ainda, que com a internet as mulheres e suas famílias têm a possibilidade de cada vez mais, conhecer a realidade das políticas públicas de outros países e entrar em contato com a literatura científica sobre essa temática. Dessa forma, é crescente no Brasil o número de movimentos populares e redes sociais que discutem a humanização do parto e nascimento, sobre o parto normal e parto domiciliar planejado; entendendo que a mulher deve ter o direito de parir onde desejar, desde que haja condições adequadas para isso.

Entretanto, Sanfelice e Shimo (2014) esclarecem que o parto domiciliar planejado no Brasil ainda é uma opção pouco explorada e que tem gerado grande polêmica, tendo em vista que o campo tradicional da medicina obstétrica considera-o como um retrocesso diante de tantos recursos disponíveis atualmente, podendo colocar em risco a vida da mãe e do bebê. Dessa maneira, ainda há pouca compreensão sobre os motivos pelos quais as mulheres optam em parir em casa, abdicando das tecnologias hospitalares. De forma contrária, na Holanda, Canadá e Austrália, o parto domiciliar planejado é reconhecido e estimulado pelo sistema de saúde, por ser considerado um modelo de assistência tão seguro quanto o parto hospitalar. As autoras acrescentam que as pesquisas nacionais sobre o tema ainda são escassas, mas já apresentam bons resultados obstétricos e neonatais, semelhantes aos estudos internacionais. Nesse sentido, Velho et al. (2012) apontam a necessidade de pesquisas qualitativas para compreensão das experiências de mulheres que vivenciaram diferentes tipos de parto.

O número de mulheres que tem optado pelo parto domiciliar planejado nos centros urbanos vem crescendo. Contudo, os estudos nessa área, principalmente a partir da 
perspectiva da mulher, ainda são escassos. Nesse contexto e partindo das considerações teóricas apresentadas, das iniciativas dos setores público e privado, movimentos populares e em redes sociais, que evidenciam a importância de uma mudança no modelo de atenção ao parto e nascimento no Brasil e ainda, da revisão bibliográfica que apresenta uma lacuna na produção científica sobre o parto domiciliar planejado; justifica-se a relevância científica e social desse trabalho, entendendo que irá contribuir para construção de conhecimento nessa área.

Vale ressaltar que o presente estudo contempla o parto domiciliar planejado, escolhido pela mulher e realizado nos centros urbanos, com assistência e equipe especializada, e não o parto domiciliar assistido por parteiras tradicionais em regiões com poucos recursos, tão pouco o parto ocorrido em casa sem o planejamento da parturiente. 
OBJETIVOS 


\section{OBJETIVOS}

\subsection{Objetivo geral}

O objetivo do presente estudo foi compreender a experiência de mulheres que optaram pelo parto domiciliar planejado, a partir de suas perspectivas.

\subsection{Objetivos específicos}

1. Compreender os motivos pelos quais as participantes optaram pelo parto domiciliar planejado;

2. Compreender os desdobramentos da escolha pelo parto domiciliar planejado, nas relações familiares;

3. Identificar e compreender os significados e sentidos atribuídos pelas participantes, à experiência do parto domiciliar planejado;

4. Conhecer as ações e procedimentos adotados pelas participantes no que se refere a preparação e ao evento do parto domiciliar planejado. 
MÉTODO 


\section{MÉTODO}

Trata-se de um estudo em abordagem qualitativa, que segundo González-Rey (2002), debruça-se sobre a subjetividade, em que a história e o contexto do sujeito marcam sua singularidade e ressalta a importância das ideias do pesquisador, enquanto sujeito, para a produção do conhecimento. Minayo (2012) refere que a vivência de um mesmo acontecimento é única para cada pessoa, pois depende de sua personalidade, biografia e participação histórica. "O verbo principal da análise qualitativa é compreender" (p. 623). Para compreender é preciso considerar a singularidade do indivíduo e também sua experiência e vivência na história coletiva.

\subsection{Aspectos Éticos}

O presente estudo foi enviado ao Comitê de Ética em Pesquisa de acordo com as resoluções: 466/12 (Ministério da Saúde, 2012b) que regulamenta pesquisas com seres humanos no Brasil e 510/16 (Ministério da Saúde, 2016b) sobre a Ética na Pesquisa na Área de Ciências Humanas e Sociais. Foi aprovado em primeira instância, sob o CAAE n ${ }^{\circ}$ 66587617.7.0000.5407 (ANEXO A). Ao entrar em contato com as participantes, a pesquisadora informou sobre os objetivos e procedimentos do estudo. No dia acordado para a entrevista, antes de assinar o Termo de Consentimento Livre e Esclarecido (TCLE, APÊNDICE A), a pesquisadora esclareceu novamente sobre os objetivos e procedimentos do estudo, suas implicações, sobre o caráter voluntário em participar da pesquisa e a possibilidade de interromper sua participação a qualquer momento, caso desejasse, assim como da autonomia para não responder a assuntos indesejáveis e também o respeito ao sigilo. As participantes, juntamente com a pesquisadora, leram e assinaram o TCLE e ficaram com uma via do documento. Todos os nomes foram substituídos por nomes fictícios visando preservar a identidade das participantes. 


\subsection{Constituicão do Corpus}

\subsubsection{Contexto do estudo}

O estudo foi realizado numa cidade de grande porte do interior de São Paulo, com população de aproximadamente 700 mil habitantes. O município conta com sete maternidades e não há casas de parto.

O ponto de partida para o contato com as participantes foi o grupo "Geração Mãe", um portal de maternidade da web que traz informações e apoia o parto natural, amamentação, criação com apego, entre outros. $O$ grupo tem uma página no Facebook (www.facebook.com/geracaomae), um site (www.geracaomae.com.br) e um instituto que oferece atendimento presencial.

\subsubsection{Participantes}

Os critérios para inclusão no estudo foram: possuir 18 anos completos ou mais e ter vivenciado o trabalho de parto e parto planejado em seu domicílio. Participaram dessa pesquisa 17 mulheres com idades entre 28 e 42 anos, todas com ensino superior completo, destas, seis com pós-graduação. Todas morando com seus companheiros e com renda média familiar de 12 salários mínimos. Todas as entrevistadas se prepararam para realizar um parto domiciliar planejado por meio de literatura especializada, filmes e documentários, participação de cursos, grupos em redes sociais e depoimentos de outras mulheres. Quanto à preparação física, a maioria fez yoga para gestantes, algumas pilates e outras fisioterapia perineal. Quatro entrevistadas, com intuito de se prepararem emocionalmente, fizeram psicoterapia. Sobre a equipe para o parto domiciliar planejado, a maior parte das participantes contou com duas enfermeiras obstetras e uma doula. Vale ressaltar que os companheiros de todas as entrevistadas estavam presentes durante o parto.

O número de participantes foi determinado pelo critério de saturação dos dados. Minayo (2009) afirma que em pesquisas de cunho qualitativo muitas vezes, se opta por definir o número de sujeitos por inclusão progressiva, sem demarcar a priori o número de participantes, que é interrompida pelo critério da saturação, quando as concepções, explicações e sentidos atribuídos pelos sujeitos começam a ter certa regularidade. 


\subsubsection{Instrumentos}

O corpus do estudo foi constituído por entrevistas abertas, individuais e áudiogravadas. Em pesquisa qualitativa, a entrevista tem o objetivo de converter-se em um diálogo que é constituído e expande seus conteúdos de forma espontânea, abrangendo áreas de interesse e outras que o pesquisador não imaginava anteriormente, mas que podem ser relevantes para o processo de construção de conhecimento (González-Rey, 2002). Para atingir os objetivos desse trabalho, foi elaborada uma questão disparadora, a saber: "Gostaria que você me contasse como foi sua experiência de ter realizado um parto domiciliar planejado". E ainda, um roteiro com temas orientadores visando contemplar os objetivos propostos. (APÊNDICE B).

Ressalta-se que foi utilizado um diário de campo onde a pesquisadora registrou suas observações, percepções e questionamentos, desde o primeiro contato com a participante; bem como alguns diálogos realizados após o término das entrevistas, propriamente dita.

\subsubsection{Procedimentos}

Compreendendo que o parto domiciliar planejado é uma prática recente nos centros urbanos, no primeiro semestre de 2016, ainda na fase de elaboração do presente estudo, a pesquisadora criou um post no grupo "Geração Mãe" do Facebook, visando verificar a viabilidade da pesquisa. A partir desse post, 11 mulheres que contemplavam os critérios de inclusão descritos anteriormente, se disponibilizaram a participar da pesquisa.

No segundo semestre de 2017, quando o projeto foi aprovado pelo CEP, a pesquisadora criou um novo post no grupo "Geração Mãe” do Facebook convidando à participação voluntária de mulheres que haviam realizado partos domiciliares planejados. A partir desse post, 13 mães se disponibilizaram a participar do estudo e enviaram seus contatos telefônicos. O segundo contato foi realizado pelo WhatsApp, em que a pesquisadora explicou melhor sobre o trabalho, tirou dúvidas e agendou as entrevistas individuais, no local de escolha de cada participante. Vale ressaltar que algumas entrevistadas indicaram outras mulheres para participar da pesquisa, totalizando 22 possíveis participantes, mas tendo em vista o critério de saturação adotado no presente estudo, foram realizadas 17 entrevistas no total.

A coleta de dados foi realizada entre outubro de 2017 a fevereiro de 2018. No momento da entrevista, inicialmente foi realizada a leitura e assinatura do TCLE, ficando uma via com a pesquisadora e outra com a participante. Na sequência foi realizada a entrevista face a face, áudio-gravada, com duração média de 60 minutos e posteriormente transcrita na 
íntegra, com o consentimento das participantes. As observações e percepções da pesquisadora e os diálogos posteriores às entrevistas foram registradas em um diário de campo, sem a presença das participantes. Vale ressaltar que está prevista uma devolutiva dos resultados do estudo às participantes, de acordo com o interesse e a disponibilidade de cada uma.

\subsubsection{Percurso da Análise do Corpus}

A análise do Corpus foi realizada por meio do método de Análise de Conteúdo Temático, proposto por Bardin (2011), que consiste em um “conjunto de técnicas de análise da comunicação, visando obter, por procedimentos sistemáticos e objetivos de descrição do conteúdo das mensagens, indicadores que permitam a inferência de conhecimentos relativos ao modo como tais mensagens foram produzidas, transmitidas e recebidas" (p. 48). O processo de Análise de Conteúdo Temático se organizou em três etapas, a saber: pré-análise, exploração do material, tratamento dos resultados obtidos e interpretação.

1. A pré-análise, consistiu na organização, na formulação das hipóteses e dos objetivos e elaboração de indicadores para fundamentar a interpretação final. Esta etapa contemplou a leitura flutuante, a constituição do corpus e a formulação e reformulação de hipóteses e objetivos.

2. A etapa seguinte, exploração do material, resultou na operação de codificação, decomposição ou enumeração, através de recortes, agregação para alcançar o núcleo de compreensão do texto.

3. Na terceira e última etapa, tratamento dos resultados obtidos e interpretação, os resultados brutos foram categorizados e a pesquisadora propôs inferências e realizou interpretações dos objetivos previstos e descobertas inesperadas, a partir da interlocução da produção científica sobre humanização do parto e nascimento, parto domiciliar, documentos do Ministério da Saúde, alguns autores da saúde coletiva e da psicanálise de Winnicott.

Ressalta-se, que as Categorias Temáticas não foram criadas a priori, mas a partir dos sentidos apresentados pelas participantes, sobre a experiência do parto domiciliar planejado. 
O quadro a seguir apresenta os recursos gráficos utilizados nas transcrições das entrevistas e seus respectivos significados.

\begin{tabular}{|c|c|}
\hline Recursos gráficos & Significados \\
\hline & Pausa no relato. \\
\hline$[\ldots]$ & Trechos suprimidos pela pesquisadora. \\
\hline “ ” & $\begin{array}{l}\text { Ênfase dada pela entrevistada, indicando reflexão ou } \\
\text { questionamento. }\end{array}$ \\
\hline (Frases entre parênteses) & $\begin{array}{c}\text { Inserção de palavras ou trechos realizados pela } \\
\text { pesquisadora, visando aumentar a compreensão do } \\
\text { relato e/ou contexto. }\end{array}$ \\
\hline
\end{tabular}

Quadro 1. Recursos gráficos utilizados na transcrição das entrevistas e seus significados. 
ANÁLISE DO CORPUS 


\section{ANÁLISE DO CORPUS}

\subsection{Descrição das participantes}

A seguir, as participantes do estudo serão apresentadas por meio de uma breve caracterização e alguns dados sobre o momento da entrevista.

1 - Alfazema tem 35 anos, fez pós-graduação em nível de doutorado e trabalha 30 horas por semana. Ela tem dois filhos e relata que nenhuma das gestações foi planejada. Sua primeira filha nasceu de um parto normal hospitalar com várias intervenções que não eram de sua vontade, como episiotomia, manobra de kristeller e anestesia. Seu segundo filho nasceu de parto domiciliar planejado com 39 semanas. Alfazema mora com o marido e seus dois filhos. Sua renda familiar é de oito salários mínimos.

2 - Amarílis tem 36 anos, curso superior completo e atualmente não trabalha, Passou por quatro gestações, das quais, na segunda gravidez, que foi planejada, sofreu um aborto espontâneo com 12 semanas. Ela relata que queria esperar pela expulsão natural do feto, mas devido a uma hemorragia, precisou de cuidados médicos. Sua primeira filha nasceu de uma gestação não planejada, de parto normal hospitalar com muitas intervenções, como episiotomia, ocitocina, exames de toque constantes, rompimento forçado da bolsa amniótica, procedimentos esses, considerados por Amarílis como violência obstétrica. Seu segundo filho foi planejado e nasceu de parto domiciliar planejado com 40 semanas e dois dias. A sua terceira filha não foi planejada e também nasceu de parto domiciliar planejado com 41 semanas e quatro dias. Amarílis mora com o marido e os três filhos. Sua renda familiar é de oito salários mínimos.

3 - Azaléia tem 38 anos, curso superior completo e trabalha cerca de cinco horas por semana. Em sua primeira gestação, sofreu um aborto espontâneo quando estava com seis semanas. Segundo Azaléia foi seu primeiro parto, pois optou pela expulsão natural do feto e assim, sentiu contrações e todas as dores. A segunda gestação foi planejada e sua filha nasceu 
de parto domiciliar planejado com 40 semanas. Azaléia mora com o marido e com a filha que amamenta. Sua renda familiar é de sete salários mínimos.

4 - Begônia tem 31 anos, curso superior completo e atualmente não trabalha. Passou por três gestações, com dois abortos. Sua primeira gestação foi nas trompas e ela precisou fazer um aborto devido as fortes dores e ainda, porque corria risco de morte. Begônia relata que se sentiu desrespeitada com o atendimento hospitalar que recebeu na ocasião. Em sua segunda gestação sofreu um aborto espontâneo com seis semanas. De sua terceira gestação nasceu um menino de parto domiciliar planejado com 40 semanas. Ela mora com o marido e o filho. A renda da família é de 12 salários mínimos.

5 - Bromélia tem 42 anos, curso superior completo e atualmente trabalha cerca de oito horas por semana. Ela teve dificuldades para engravidar, realizou alguns tratamentos, mas acabou engravidando naturalmente. Passou por quatro gestações planejadas, das quais, sofreu dois abortos espontâneos, na primeira e terceira gestações. No primeiro aborto estava com oito semanas gestacionais e precisou de atendimento hospitalar para fazer uma curetagem. Segundo ela, foi um luto tardio e difícil de elaborar, pois o viveu nove meses depois do aborto, momento em que seria o nascimento do bebê. Sobre o segundo aborto, ela não relatou detalhes. Seu primeiro filho nasceu com 40 semanas e um dia, de parto domiciliar planejado. Sua segunda filha também nasceu de parto domiciliar planejado, com 39 semanas e um dia. Bromélia mora com o marido, seus dois filhos e com a enteada. A renda da família é de aproximadamente 40 salários mínimos. No final da entrevista ela mostrou fotos de seus partos e depois enviou a pesquisadora, os respectivos vídeos dos partos.

6 - Dália tem 32 anos, tem pós-graduação e trabalha 60 horas semanais. Tem dois filhos, o primeiro fruto de uma gravidez planejada, nasceu com 41 semanas e três dias, de parto domiciliar planejado. Dália o amamentou até os cinco anos. O segundo nasceu de cesárea. Dália mora com o marido e os filhos. Sua renda familiar é de 14 salários mínimos. 
7 - Gérbera tem 40 anos e é mãe de três filhos, tem curso superior completo e atualmente não tem horário fixo de trabalho. Segundo ela, sua primeira filha nasceu de parto normal hospitalar com intervenções como episiotomia, anestesia sem seu consentimento e afastamento precoce mãe e bebê. Gérbera conta que no nascimento de sua segunda filha quando chegou ao hospital, o trabalho de parto já estava bem avançado. Por essa razão, não houve tempo para intervenções no parto normal, mas novamente vivenciou afastamento precoce mãe e bebê. Sua terceira gestação não foi planejada, da qual nasceu um menino de parto domiciliar planejado com 38 semanas e cinco dias. Gérbera mora com o marido e os filhos. Sua renda familiar é de cinco salários mínimos.

8 - Hortência tem 37 anos, fez doutorado e trabalha 40 horas por semana. Passou por três gestações, sendo a terceira, um aborto espontâneo. Seu primeiro filho não foi planejado, nasceu de parto normal hospitalar com algumas intervenções. O segundo filho foi planejado, nasceu de parto domiciliar planejado com 39 semanas e cinco dias e foi amamentado até os três anos. Sobre o aborto, ela relata que estava com 11 semanas gestacionais quando perdeu o bebê, mas pelo ultrassom, estava com cinco semanas. Hortência optou pela expulsão natural do feto, que segundo ela foi muito dolorosa e intensa, que a vivenciou como um trabalho de parto. Ela mora com o marido e os filhos. Sua familiar é de oito salários mínimos.

9 - Jasmim tem 32 anos, curso superior completo, trabalha 30 horas por semana e tem dois filhos. Segundo ela, seu primeiro filho não foi planejado e nasceu de parto normal hospitalar com várias intervenções, como ser impedida de se alimentar durante o trabalho de parto, tricotomia perineal (raspar os pelos pubianos), usar ocitocina para indução do parto, manobra de Kristeller e separação precoce mãe e bebê. Seu segundo filho nasceu de parto domiciliar planejado com 40 semanas e dois dias. Jasmim mora com o marido e os filhos. Sua renda familiar é de oito salários mínimos.

10 - Lavanda tem 41 anos, cursa pós-graduação em nível de mestrado. Passou por quatro gestações, sendo as duas primeiras, abortos espontâneos com oito semanas gestacionais. Seu primeiro filho nasceu de parto normal hospitalar com várias intervenções, sendo que o uso da ocitocina contra sua vontade foi considerado por ela como violência 
obstétrica. Seu segundo filho nasceu de parto domiciliar planejado com 39 semanas e cinco dias. Ela mora com o marido e os filhos. A renda familiar é superior a cinco salários mínimos. Lavanda está grávida de seu terceiro filho e pretende realizar um parto domiciliar.

11 - Margarida tem 35 anos, curso superior completo e trabalha cerca de 20 horas semanais. Tem dois filhos nascidos de partos domiciliares planejados e está grávida do terceiro, também planejado para nascer em casa. Seu primeiro filho nasceu com 37 semanas. Seu segundo filho nasceu de 40 semanas, em um trabalho de parto mais rápido que o primeiro. Ela mora com o marido, os filhos e seus dois enteados. Sua renda familiar é de oito salários mínimos.

12 - Mimosa tem 28 anos, curso superior completo e está retornando ao trabalho de 30 horas semanais, após a licença maternidade. Sua filha nasceu de parto domiciliar planejado com 37 semanas e seis dias. Mimosa mora com o marido e a filha. Sua renda familiar é de seis salários mínimos. Após a entrevista, ela mostrou a pesquisadora, fotos do seu parto, por meio do celular.

13 - Orquídea tem 41 anos, fez pós-graduação, trabalha 40 horas semanais. Passou por problemas hormonais e dificuldades para engravidar, realizou duas fertilizações sem sucesso e engravidou naturalmente. Ela relata que teve certa dificuldade de vínculo e com a amamentação com seu primeiro filho, que nasceu de cesárea agendada e foi separado dela precocemente. Sua segunda filha nasceu de parto domiciliar planejado com 39 semanas e quatro dias. Orquídea mora com o marido e os filhos. Sua renda familiar é de 40 salários mínimos.

14 - Petúnia tem 36 anos, curso superior completo, atualmente não trabalha. Tem dois filhos que foram planejados e nasceram de partos domiciliares planejados. O primeiro nasceu com 39 semanas e cinco dias e segundo ela, após o parto teve dificuldades com a amamentação. O segundo nasceu de 38 semanas e três dias. Petúnia faz amamentação em tandem, que é quando a mãe amamenta dois filhos com idades diferentes. Ela mora com o 
marido e os filhos e não informou a renda familiar. Ao final da entrevista, Petúnia mostrou algumas fotos das gestações e dos filhos, que estavam em porta-retratos.

15 - Rosa tem 35 anos, curso superior completo e é autônoma. Tem dois filhos, ambos nascidos de partos domiciliares planejados. Ela relata que o primeiro nasceu com 39 semanas, com desconforto respiratório, mas que logo foi estabilizado pelas enfermeiras. Relata ainda, que teve dificuldades com a amamentação. Sua segunda filha nasceu com 38 semanas. Rosa mora com o marido e os filhos. A renda familiar é de 10 salários mínimos. Ao final da entrevista, ela mostrou a pesquisadora, fotos dos partos que estavam em seu computador.

16 - Tulipa tem 35 anos, possui pós-graduação em nível de mestrado e trabalha cerca de 20 horas semanais. Passou por três gestações, nenhuma planejada. Segundo ela, sua primeira filha nasceu de uma cesárea desnecessária. A segunda filha nasceu de parto normal hospitalar com intervenções como o uso de ocitocina, rompimento forçado da bolsa e episiotomia, procedimentos que foram considerados por ela, como violência obstétrica. Sua terceira filha nasceu de parto domiciliar planejado com 40 semanas. Tulipa mora com o marido e as filhas. Sua renda familiar é de sete salários mínimos.

17 - Violeta tem 32 anos, curso superior completo e trabalha cerca de 30 horas por semana. Tem dois filhos, ambos de partos domiciliares planejados. O primeiro nasceu com 40 semanas e teve dificuldades com a amamentação. Sua segunda filha nasceu com 39 semanas e nos três primeiros meses ela amamentou os dois filhos juntos (amamentação em tandem). Violeta mora com o marido e os filhos. Sua renda familiar é de 15 salários mínimos.

A descrição das participantes foi compilada e encontra-se no quadro A (APÊNDICE C). 


\subsection{Categorias Temáticas a partir da análise das entrevistas realizadas}

A partir da análise do Corpus foi possível a organização de seus conteúdos em três Categorias Temáticas e suas subcategorias correspondentes, apresentadas no quadro 2.

\begin{tabular}{|l|l|}
\hline \multicolumn{1}{|c|}{ CATEGORIAS } & \multicolumn{1}{|c|}{ SUBCATEGORIAS } \\
\hline $\begin{array}{l}\text { 5.2.1 Escolha pelo parto } \\
\text { domiciliar planejado }\end{array}$ & \\
\hline $\begin{array}{l}\text { 5.2.2 Família e o processo } \\
\text { do parto domiciliar } \\
\text { planejado }\end{array}$ & \begin{tabular}{l} 
5.2.3.1 Parto controle \\
\hline $\begin{array}{l}\text { 5.2.3 Sentidos do parto } \\
\text { domiciliar planejado }\end{array}$
\end{tabular} \\
& $\begin{array}{l}\text { 5.2.3.2 Parto romântico e } \\
\text { idealizado }\end{array}$ \\
& 5.2 .3 .3 Parto poder \\
\hline
\end{tabular}

Quadro 2. Categorias Temáticas e subcategorias correspondentes.

A seguir, serão descritas as Categorias Temáticas e subcategorias correspondentes.

É importante ressaltar que a expressão "processo de parto", referida no presente estudo, inclui desde a preparação para o parto domiciliar planejado até o pós-parto e não apenas o momento do parto. 


\subsubsection{Escolha pelo parto domiciliar planejado}

Essa categoria apresenta as principais motivações para o parto domiciliar, partindo das experiências da maioria das participantes no ambiente hospitalar e por aquelas que não haviam passado por essas vivências, mas que também desejavam um parto mais natural, sem as intervenções hospitalares de rotina. Vale ressaltar, que entre as 17 participantes, 11 já haviam passado por experiências hospitalares, como partos anteriores ou intervenções decorrentes de abortos.

Os relatos a seguir apontam que as intervenções realizadas em partos hospitalares anteriores foram a principal motivação para que as participantes optassem posteriormente, por um parto em casa:

O parto primeiro... foi por ter percebido que alguma coisa tava estranha que tava errada e aí, ir atrás. E ai ela (médica) falou: "com 40 semanas não pode passar disso". E aí nós optamos por induzir, porque eu queria normal de qualquer forma. E ai ela falou: "já que você não quer cesárea, vamo induzir”. E deu muita dó, eu já tinha saído o tampão, tava assim, que pra ali dois dias eu ia entrar em trabalho de parto. E aí ela induziu, colocou o soro né, com ocitocina, foi super rápido porque pelo o que ela falou eu já tava com cinco centímetros de dilatação sem sentir nada. Era um menino pequenininho, ia ser super tranquilo. Eaí induziu, eu assim... né, você não tem o andar natural do parto né, com a ocitocina. Então acabou que eu senti mais dor do que deveria, o tempo inteiro, eu não consegui nem sair da maca [...] por causa da ocitocina. E... e eu não entendia nada, pra mim tava tudo certo né. Eu nunca tinha estudado, só sabia que eu queria normal. E aí ela fez tooodos os procedimentos que hoje eu sei, são desnecessários: raspou os pelos, pediu pra eu não comer, na hora do parto a gente foi pra sala cirúrgica e aí os médicos subiram em cima de mim, aquela manobra de Kristeller. E eu falava: "eu não tô conseguindo respirar"! Eu falava pra eles, eles falavam: "tem que empurrar se não ele sobe". "Claro que sobe, deitada sobe né". E ai eu tava: "eu não tô conseguindo respirar! Sai de cima de mim”! Eles: "ah, ele já tá vindo, já tá vindo”. Nasceu. Eu tava super feliz, pra mim aquilo lá era o normal, o certo. Ela mandou um pique ali em mim nervoso (episiotomia), grande, desnecessário! Um menino de dois quilos e meio. Totalmente desnecessário! Mas foi... Isso me fez começar a olhar, depois que ele nasceu. Ele nasceu 11:30 da noite, me levaram ele ali da sala do centro cirúrgico e só me entregaram ele 8:30 da manhã do outro dia. Imagina, nove meses com um bebê e aí depois que você olha pra carinha dele e quer ter ele perto de você, você fica a noite inteira esperando. "Dorme mãe, descansa". "Dorme mãe, descansa", fala sério né?! Eu passei a noite inteira com o olho arregalado, conversando com a outra que tinha tido parto normal, que também estava esperando o bebê dela. E aí acabei ficando sem ele o tempo inteiro. Isso pra mim foi muito ruim, porque eu não sei o que foi feito lá, o que, se deram alguma coisa pra ele antes, leite. Não era pra fazer isso! Era o meu leite! Tanto que lá, na cirurgia, no centro cirúrgico, eles pediram e eu: "quero que põe pra mamar". E eles: "não mãe, ele não mama não"! E eu já achei muito esquisito essa história, sabe. E aí depois passou... eu não pensei muito mais nisso. Quando eu engravidei do segundo eu comecei a pensar: "gente, alguma coisa não tá legal, não tá certo". E aí eu vi pelo (cita um grupo do Facebook), os posts das mães que tinham tido parto humanizado, parto domiciliar [...] depois que eu descobri o quanto foi ruim, desnecessário, eu não quero mais, ainda mais porque eu quero meu filho perto de mim o tempo inteiro". (Jasmim) 
Então, eu já tinha vontade de fazer antes, dede a minha primeira gestação, mas eu acho que quando o parto da minha filha saiu totalmente do que eu esperava né, então acho que pode ter sido isso também, além de já ter aquela vontade. Mas aí assim, foi um parto assim, que eu por mais que eu conversei com minha obstetra, falei, sabia do que tava acontecendo, ela então... o fato de ter tido a episio, a manobra de Kristeller e na verdade até a anestesia foi contra a minha vontade. Porque eu pedi pra ela, falei que não queria anestesia e ai ela falou: "não, você tá muito cansada, você precisa da anestesia". Então eu acho que tudo isso fez eu não querer, e mesmo assim, o pós-parto da minha filha foi muito ruim, na maternidade né. Desde, como ela nasceu em fevereiro, as enfermeiras ficava querendo colocar ar condicionado muito gelado. Tipo, são coisinhas, mas que pra mim pegou muito naquela época. Então falei assim: "não quero isso, não quero". Tipo, colocaram ela no ar condicionado super gelado. (Alfazema)

Os motivos pelo parto domiciliar, foram os principais, os procedimentos de rotina... mesmo com uma equipe de parto humanizado, num hospital humanizado, num quarto de pré-parto e pós-parto e mesmo empoderadíssima de informação, tive, fui vítima de dois procedimentos de rotina. $O$ uso da ocitocina, inclusive, considero violência obstétrica né e aí eu não queria passar por isso de novo. (Lavanda)

[...] eu fui para o parto domiciliar porque eu tive o parto da Bruna hospitalar, eu nunca havia pensado em parto domiciliar assim, eu queria muito o parto normal. E aí quando eu tive o parto normal da Bruna, eu não tinha tanta informação, eu tinha, mas não o suficiente. Eu tive muita intervenção [...] depois de muito tempo eu fui estudar, eu ouvi que isso era violência obstétrica, coisa que eu nunca tinha ouvido falar na minha vida entendeu. Então eu saí daquele parto da Bruna, assim, nunca mais quero ter filho porque eu não quero uma cesárea e não vou passar por um parto normal de novo. [...] no parto foi muito dolorido para mim o parto dela né. Então eu tive todas as intervenções, eu tive a episiotomia, que a laceração demorou seis meses para cicatrizar, eu tive que usar antibiótico. É eu tive exame de toque o tempo todo, a médica com o dedo dilatava o meu útero, doía muito. Romperam minha bolsa, eu tive ocitocina, aquela posição deitada. Então foi, eu falei: "Nossa Senhora né, que que é isso"? E ai eu falei: "gente eu nunca mais quero ter filho na vida". E ai eu comecei a ler mais ainda e vê que né, não precisava ter passado por aquilo tudo e que essa coisa do parto humanizado né, da mulher ali, como o principal, o respeito com ela e com a criança. (Amarílis)

Segundo Jasmim, devido ao uso da ocitocina, ela sentiu "mais dor do que deveria, o tempo inteiro" [sic]. Hidalgo-Lopezosa, Hidalgo-Maestre e Rodríguez-Borrego (2016) apontam que a ocitocina sintética é bastante utilizada na obstetrícia para induzir e acelerar o trabalho de parto, aumentando as contrações uterinas. Entretanto, pode provocar efeitos negativos como o aumento significativo da dor e assim, desencadear o uso da analgesia. Jasmim, Alfazema, Lavanda e Amarílis, de diferentes modos relatam ainda, outros procedimentos vividos no hospital, como a tricotomia (raspar os pelos pubianos), exames de toque, amniotomia (romper a bolsa amniótica), posição de litotomia (posição ginecológica), manobra de Kristeller (empurrar a barriga para forçar a descida do bebê), episiotomia (incisão 
cirúrgica na região do períneo) e a separação precoce dos seus bebês, que assim como a ocitocina, também foram considerados por elas, como procedimentos desnecessários e desrespeitosos.

Esses procedimentos não são recomendados pela OMS, contudo, o modelo de assistência ao parto e nascimento no Brasil é caracterizado pelo uso de tecnologias médicas e um atendimento protocolar que se sobrepõe a escuta do paciente (Leal \& Gama, 2014 e Aquino, 2014). O relato de Alfazema aponta que o uso da anestesia durante o parto de sua filha foi uma opção médica e contra sua vontade, assim como a episiotomia e a manobra de Kristeller. Nesse sentido, Alfazema relata que não teve suas necessidades atendidas pela equipe de saúde.

De acordo com Hiene (2018), com o desenvolvimento das tecnologias médicas, o parto que era compreendido como um ato feminino realizado em casa e apoiado por mulheres, passou a ser tratado como "doença", dependente de cuidados hospitalares. O modelo hospitalar vigente de atenção ao parto é caracterizado pela supremacia das tecnologias médicas, deixando as relações humanas em segundo plano. Com a intenção de abreviar o processo de parto são utilizadas medicações e intervenções dolorosas onde prevalece a ideia de passividade das mulheres nesse processo. A autora refere que esse modelo é centrado na "figura médica e na incapacidade do corpo da mulher de parir um bebê" (p. 40).

Jasmim, embora desconhecesse todo processo do parto, refere grande desconforto com os procedimentos realizados durante seu parto e pós-parto, dessa maneira, ela intuiu que “alguma coisa estava estranha” [sic], embora não soubesse nomear. Foram realizados vários procedimentos considerados por ela, posteriormente, como desnecessários, inclusive a manobra de Kristeller que lhe causou dificuldade para respirar. Por outro lado, Lavanda mesmo "empoderadíssima de informação" [sic] também passou por procedimentos de rotina considerados por ela como violência obstétrica, assim, estar informada sobre o processo do parto não a protegeu do que ela caracterizou como violência. Desse modo, com ou sem informação, segundo as participantes, houve desconforto, não houve escuta e a escolha sobre a realização dos procedimentos ficou nas mãos dos profissionais.

Barros (2002) aponta que no contexto do processo saúde-doença o modelo biomédico compreende o corpo como uma máquina complexa e imperfeita, que tem ou terá problemas que só um especialista poderá inspecionar, detectar e resolver. Dessa forma, as doenças só podem ser detectadas por métodos científicos, não havendo espaço para as questões sociais, psicológicas e comportamentais do adoecimento. Segundo o autor, a formação médica afasta 
o médico do desejo do paciente e dessa forma, o "dono do saber" passa a não escutar o "dono do corpo" (p. 53). A incorporação das tecnologias médicas trouxe vários benefícios à saúde, mas também produziu novos riscos como a iatrogenia, níveis exagerados de especialização, institucionalização dos cuidados de saúde e interferiu na relação médico-paciente, provocando um distanciamento dos mesmos.

Winnicott (1965/2006) descreveu a importância da "familiaridade", ou seja, da comunicação e do vínculo da mulher com a equipe de profissionais de saúde desde a gestação, para que possa delegar a estes, certas responsabilidades referentes ao parto. Entretanto, no presente estudo, a dificuldade de comunicação com a equipe foi observada nos relatos de algumas participantes que já haviam passado por partos hospitalares, como exemplifica Jasmim, ao comunicar à equipe que não estava conseguindo respirar e ainda assim, eles continuaram com a manobra de Kristeller. Atualmente, contrário ao pensamento de Winnicott, que refere a importância do vínculo da parturiente com a equipe, grande parte dos partos hospitalares são realizados com médicos e enfermeiros plantonistas que não tiveram contato anterior com a gestante e isso pode estar dificultando a comunicação e o vínculo entre a mulher e a equipe.

Sobre a comunicação da gestante com a equipe, observou-se que a maioria das participantes do presente estudo não teve suas necessidades e desejos ouvidos pelos "donos do saber". Foram submetidas a procedimentos que lhes causaram dor e sofrimento durante o trabalho de parto, parto e pós-parto, alguns destes, sem seu consentimento, reiterando um lugar de passividade e não escuta de suas necessidades e reafirmando a autoridade dos profissionais. O uso dos protocolos hospitalares e das tecnologias prevaleceu até no momento de ligar o "ar condicionado muito gelado" [sic], sendo percebido por Alfazema como desrespeitoso e indicando não haver espaço para um diálogo entre a parturiente e a equipe. Dessa maneira, no contexto hospitalar, parto e nascimento parecem ser compreendidos pela equipe de saúde como uma sucessão de procedimentos que se sobrepõem ao protagonismo da mulher.

Sobre um estudo com mulheres, que após vivenciarem partos hospitalares optaram por realizar um parto domiciliar, Castro e Azevedo (2018) apontam que as participantes se sentiram vulneráveis no hospital, onde foram cercadas de procedimentos aversivos, receberam tratamento ríspido da equipe e ausência de informações. Em alguns desses hospitais não foi permitida a presença do acompanhante, o que gerou um sentimento de solidão nas 
parturientes. Os bebês foram submetidos a vários procedimentos e separados precocemente das mães, provocando dificuldades com a amamentação. Nesse contexto, o relato de Jasmim exemplifica tais dificuldades, uma vez que ela não pôde amamentar seu filho na hora do nascimento e nas primeiras horas de vida, sendo comunicada de que: "não mãe, ele não mama não" [sic] e em seguida, separada do seu bebê. Ela expressa seu sofrimento, pois queria ter seu filho com ela para cuidar e amamentar, mas não teve suas necessidades e desejos ouvidos. Era uma mãe sem nome e sem voz.

A despeito do cuidado das mães com seus bebês, Winnicott (1956/1993) refere que no final da gestação até algumas semanas depois do parto, a mulher desenvolve uma condição psicológica denominada por ele, como preocupação materna primária. É um estado de sensibilidade aumentado, retraído, dissociado ou perturbado a um nível mais profundo, em que a mãe se identifica intuitivamente com o filho para responder às suas necessidades e assim, fornecer um setting para a constituição do bebê. Segundo o autor, a princípio, a mãe vai atendendo as necessidades corporais e emocionais do bebê e a partir desse vínculo, a mãe suficientemente boa responde as necessidades do bebê, oferecendo a ele a ilusão temporária de onipotência, protegendo-o das angústias primárias.

Nesse contexto, os relatos de Jasmim e Alfazema apontam uma preocupação e um desejo de cuidar não só das necessidades básicas de seus filhos, como a amamentação e a temperatura do ambiente. Havia uma necessidade de acolher, proteger e sustentá-los emocionalmente. Para Winnicott (1956/1993, 1960/2008) a essência da experiência infantil é dependente do cuidado materno, assim, o potencial que é herdado pelo bebê se desenvolve pela maternagem. Dessa maneira, uma das funções da mãe suficientemente boa é o holding (sustentação) que designa não apenas o cuidado físico com o bebê, que ainda é totalmente dependente da mãe, mas também uma provisão ambiental realizada num campo psicológico complexo.

Nessa perspectiva, as participantes desse estudo referem que a escolha pelo parto domiciliar se deu como uma alternativa frente a recusa de submissão aos procedimentos hospitalares de rotina que já haviam vivenciado antes. O estudo de Heine (2018) corrobora que a maior motivação pela escolha do parto domiciliar é a fuga do modelo de atenção ao parto hospitalar, considerada violenta e desrespeitosa. A autora aponta que as mulheres que já haviam passado por experiências de partos hospitalares relataram maus tratos e violência obstétrica, como a sugestão do uso da ocitocina, desrespeito com a presença do companheiro 
e a falta de comunicação da equipe com o casal. Dessa forma, de acordo com a autora, a escolha por ter um filho em casa busca evitar intervenções desnecessárias e viver o processo do parto de forma mais natural.

Amarílis passou por vários procedimentos no parto de sua primeira filha, considerados por ela como violência obstétrica. Percebe-se que essa experiência foi vivenciada como um trauma, uma vez que ela afirma: "eu nunca mais quero ter filho na vida" [sic]. De acordo com Feyer, Monticelli e Knobel (2013) para alguns casais, as experiências anteriores com partos hospitalares foram determinantes para a escolha do parto domiciliar.

Os relatos sugerem que por meio das experiências de partos anteriores, as participantes puderam entrar em maior contato consigo mesmas e com seus bebês. Buscaram não só mais informações, como também puderam compreender e ressignificar suas experiências através de novas escolhas e pela busca de um novo sentido para o processo de parto.

A seguir, Tulipa relata sobre seus partos anteriores e sua motivação para o parto domiciliar:

[...] eu vim de uma história de um primeiro parto, de uma cesárea desnecessária. Passei na minha segunda filha, por um parto normal hospitalar com todas as intervenções possíveis. $E$ aí, a partir deste momento, deste segundo parto que foi bem traumático, eu procurei alguma coisa que legitimasse a sensação de invasão que eu tinha sentido. [...] com certeza foi um trauma de, do próprio esquema do hospital né. Eu queria fugir... eu não idealizava um parto lindo maravilhoso assim, na banheira, não era. Eu não queria era estar num hospital, é tudo o que eu sabia, que o lugar que eu não me sentiria segura seria num hospital. Então o domiciliar era a minha próxima né, escolha natural, entre aspas. E pelo fato exatamente de não, ninguém, de colocar a mão em mim desnecessariamente né. Então não ia ter intervenção de ocitocina, não ia ter, ninguém ia estourar minha bolsa, ninguém ia me fazer uma episio, ninguém ia fazer nenhuma intervenção né. Que esta intervenção cascata que na hora que a gente vê, já virou uma cesariana desnecessária. (Tulipa)

Tulipa afirma que passou por uma cesárea desnecessária no nascimento de seu primeiro filho. Nesse sentido, a pesquisa "Nascer no Brasil" (Vasconcelos et al., 2014) aponta que $70 \%$ das brasileiras no início da gestação desejam ter um parto vaginal, contudo, durante o pré-natal parece haver uma indução para a aceitação da cesárea (Domingues et al., 2014). Segundo Salgado (2012), o uso inapropriado de tecnologias na assistência à gestação e ao parto e o uso excessivo de medicalização nas gestações de baixo risco, também são fatores que contribuem para o número elevado de cesáreas no país; o que é exemplificado através do relato de Tulipa: "que esta intervenção cascata que na hora que a gente vê, já virou uma cesariana desnecessária” [sic]. A fala de Tulipa revela ainda, um sofrimento referente aos 
seus partos anteriores, que segundo ela, causou um trauma em relação ao ambiente hospitalar e legitimou uma sensação de invasão e a escolha pelo parto domiciliar.

Diferente das participantes citadas nos relatos anteriores, Margarida e Rosa não tinham filhos e não haviam passado por experiências hospitalares anteriores. Contudo, as principais motivações que as fizeram optar pelo parto domiciliar foram semelhantes às demais participantes, o desejo de um parto mais natural e não vivenciar as intervenções hospitalares de rotina.

[...] porque minha mãe teve nós três de parto normal. Então, tipo eu nunca imaginei assim: "cesárea, isso existe"? Achava que era para uma coisa urgente né e porque eu nunca tinha pensado sobre isso. Aí quando alguém me falou que acontecia muito, eu estava com três meses de gestação, ai eu falei: "pelo amor de Deus, ninguém vai me cortar não". Aí eu procurei uma doula. [...] mas eu procurei ela tipo, chorando e falando: "nossa eu ouvi falar que muita gente faz cesárea sem precisar, é isso mesmo"? Ai ela começou a contar assim, dos dados absurdos, aí a partir daí, a gente começou a seguir um caminho longo assim, eu e o meu marido. Eu fazia yoga e fiz um curso de parto também e foi no curso, quando eu estava com seis meses, que elas falaram que existia parto domiciliar. Eu não sabia... não, porque nunca tinha conhecido ninguém e eu achava que era uma coisa que acontecia sem querer, não que a pessoa planejava. Eu nunca tinha pensado sobre o assunto. Aí ela colocou assim, tipo cinco minutos do curso, falando que existia, aí eu e meu marido, a gente já se olhou. Acabou o curso, a gente foi falar com ela: "como assim? Então é isso". Porque eu estava acompanhando com um médico que faz parto normal, mas é super intervencionista [...] aí a gente pegou e falou: "então a gente quer que nasce assim, em casa né”. (Margarida)

A primeira coisa eu acho que foi hospital, eu não via muito o porque de ir pra um. Eu nunca fui internada, eu nunca precisei ser internada pra nada, eu nunca fui num hospital pra nada. E eu não pensava no parto como sendo algo que tivesse que ocorrer dentro de um hospital, porque sempre vem aquela imagem de você ir porque você precisa, porque está com um problema né. [...] e não é assim que a gente via a gravidez. Pra que que a gente vai pra um hospital se a gente tem opção de estar aqui, já no nosso ambiente, com as pessoas que a gente gosta, que a gente escolheu por perto? (Rosa)

Os relatos de Margarida e Rosa apontam que elas desejavam um parto de forma mais natural e sem intervenções hospitalares de rotina. Para Margarida, o natural era ter um parto normal, assim como aconteceu com sua mãe e a cesárea seria para casos de emergências. Contudo, durante a gravidez, ela se surpreendeu ao descobrir a frequência das cesarianas e temia passar por uma, de forma desnecessária, assim como aconteceu com Tulipa. Margarida relata que também se surpreendeu com a possibilidade de realizar um parto domiciliar planejado: "porque nunca tinha conhecido ninguém e eu achava que era uma coisa que acontecia sem querer, não que a pessoa planejava” [sic]. Dessa maneira, Margarida e Rosa 
também fizeram suas escolhas pelo parto domiciliar por considerarem o hospital como um lugar relacionado às doenças, para "uma coisa urgente" [sic], para "ir porque você precisa, porque está com um problema" [sic], contrastando com a compreensão que tinham sobre a gestação e o parto.

Assim como Margarida e Rosa, Dália não tinha passado pela vivência de parto, no entanto, devido sua experiência profissional, ela também temia passar por intervenções hospitalares, como aponta o relato a seguir:

O que me levou a ter o parto em casa foi por ter passado em estágio durante muito tempo na (nome da maternidade pública) e ter ficado muito traumatizada com a assistência ao parto. Eu achava a assistência muito violenta, tanto a cesárea quanto o parto normal. Não aceitava a separação do meu filho, então assim, ir pro berçário era algo que eu não aceitava. Alguns tipos de intervenção nele eu também não aceitava. E aí eu engravidei tal e o que a gente tinha naquela época era um parto no (nome da maternidade particular) com médico. Meu médico pré-natalista na época, ele até atendia parto vaginal e tal, mas era cheio de intervenções, ocitocina, episiotomia, analgesia. Mas, o que mais me fez querer realmente uma outra via de parto, foi a questão da separação entre a mãe e o bebê que aconteceria como protocolo na maternidade que eu teria meu filho. (Dália)

Dália, por ser profissional na área da saúde e estagiar em uma maternidade pública, acompanhou várias cesáreas e partos normais, que segundo ela, tinha uma "assistência muito violenta" [sic]. Ela relata que optou pelo parto domiciliar planejado porque não queria passar pelas intervenções de rotina e se separar de seu bebê após o nascimento, o que era frequente nos partos hospitalares. Nesse sentido, a análise das entrevistas apontou que mesmo para as participantes que não haviam passado por experiências hospitalares, o hospital foi considerado como um ambiente desfavorável para o nascimento de um filho, visto que representava um lugar ligado às doenças e emergências e elas desejavam um parto de forma mais natural e sem as intervenções hospitalares de rotina.

Nesse contexto, Winnicott (1960/2008) refere que o desenvolvimento humano e seus processos de maturação dependem de um ambiente suficientemente bom. $\mathrm{O}$ autor considera que um ambiente suficientemente bom permite à mãe desenvolver condições para acolher as satisfações, ansiedades e conflitos inatos de seu bebê. Araújo (2005) esclarece que o conceito winnicottiano de ambiente refere-se às condições psicológicas (internas) e físicas (externas) para o amadurecimento, dessa forma, a capacidade de adaptação do ambiente pode possibilitar ao ser humano, perceber e se relacionar com o outro e consigo mesmo. 
De acordo com os relatos apresentados e considerando o pensamento de Winnicott (1960/2008) sobre o ambiente e os processos de maturação, que se estendem à vida adulta, compreende-se que o hospital foi significado como um ambiente que não foi ou não poderia ser suficientemente bom nem para as participantes, nem para seus bebês. Onde as condições oferecidas foram ou poderiam ser insuficientes às suas necessidades, sob o risco de suas subjetividades ficarem silenciadas, provocando angústia, solidão, medo, sensação de abandono e invasão.

\subsubsection{Família e o processo do parto domiciliar planejado}

Essa categoria aborda o posicionamento das participantes em relação aos familiares, sobre a escolha pelo parto domiciliar planejado e como essas famílias reagiram diante desse processo.

Os relatos a seguir descrevem a opção das participantes de não compartilharem com seus familiares a escolha pelo parto domiciliar, e suas motivações para tal silenciamento:

E ninguém da minha família sabia, todo mundo achou que eu ia continuar acompanhando meu parto com meu médico cesarista, tudo certinho (risos) e que ele, ele super prometia pra mim que ia fazer um parto normal. [...] então, porque ninguém nunca tinha tido nem um parto normal, tava todo mundo super apreensivo que eu queria um parto normal, porque eles achavam que eu queria muito, que ia ser a todo custo, ia ser sofrido, uma coisa assim. Então a gente preferiu não contar, porque era uma coisa muito nova pra todos eles também. E a gente continuou fazer o pré-natal com o médico, acompanhamento com as parteiras e decidiu ter em casa. (Violeta)

Então assim, eu não contei pra ninguém, por conta, nem pra minha mãe. Tipo assim, só eu, o Fabiano (marido), a Nicole (enteada) que sabia do parto domiciliar e a minha equipe. [...] eu não queria me contaminar do medo dos outros, porque assim, eu e meu marido, o que a gente mais desejava no mundo era ter filho, a gente não ia se aventurar num gosto, até porque eu mesma tinha muitos "pré-conceitos" e criticava quando eu ouvia falar sobre: teve parto em casa. "Ela é louca, não precisa disso em pleno século XXI", desse jeito. Então assim, eu não queria isso, que eu era também, entendeu? Porque assim, o "pré-conceito" é quando a pessoa tem conceitos pré-definidos. Ninguém estudou o tanto que eu e meu marido, nos preparamos com informação consistente, pra tomar decisão de uma coisa que era muito importante pra nossa vida, que era ter filho. O parto não era o que era mais importante, o filho era o mais importante. Só que se a via de parto mais gostosa, mais assim de prazer, mais de tranquilidade, era domiciliar, que foi a que a gente chegou na conclusão; eu quis. Não quis dividir e ser contaminada, a minha mãe, eu tinha medo da minha mãe ficar rondando a casa ou dar um PT, falar, ficar ouvindo sabe. (Bromélia) 
Violeta e Bromélia tinham receio de serem influenciadas com os medos dos familiares e por essa razão decidiram não contar para nenhum deles sobre o parto domiciliar. Considerando a importância da família enquanto ambiente acolhedor e protetor tanto para a gestante quanto para o bebê, compreende-se que as relações familiares no contexto do parto domiciliar planejado se torna um desafio, uma vez que a escolha por esse tipo de parto pode ser geradora de medos, fantasias, julgamentos, preconceitos e desinformação. Nesse sentido, Dezan (2015) refere a importância que a família ocupa, uma vez que ela constrói o elo inicial entre o indivíduo e a sociedade no processo de humanização e socialização e tem a função de oferecer condições de sobrevivência, suprimento das necessidades afetivas, transmissão de normas, valores pessoais e culturais.

Sobre as relações familiares, Winnicott (1957/2013) aponta que cada família tem seu próprio desenvolvimento, onde a princípio, o indivíduo que é indistinto da mãe percorre uma longa jornada para se tornar um indivíduo separado. Entretanto, tem no pai e na mãe suas características estruturais. Winnicott (1963a/2008) esclarece que na fase de dependência absoluta, que se inicia logo após o nascimento, o bebê encontra-se totalmente dependente dos cuidados maternos, mesmo não tendo consciência disso. À medida que há um desenvolvimento emocional, o bebê passa para a dependência relativa, caminhando rumo à independência. Contudo, segundo o autor, os adultos raramente atingem a maturidade completa, uma vez que conciliam a necessidade de estabelecer uma identidade pessoal e a imitação com os pais.

Nesse contexto, mesmo que decididas a realizar um parto domiciliar, os relatos de Violeta e Bromélia sugerem uma "separação" parcial e transitória com a família. Violeta rompe com as tradições familiares ao afirmar que "ninguém nunca tinha tido nem um parto normal" [sic]. Bromélia refere que juntamente com o marido, estudou muito antes de optar pelo parto domiciliar, contudo, não quis compartilhar sua decisão por medo de "ser contaminada" [sic] pela opinião das outras pessoas, especialmente de sua mãe. A fala de Bromélia, assim como de outras participantes desse estudo, revela a dificuldade de caminhar rumo à independência e se tornar um indivíduo separado dos pais, ainda que parcialmente, como aponta Winnicott (1957/2013, 1963a/2008); considerado a importância de manter e preservar os vínculos familiares. Dessa forma, as participantes não assumiram para a família a escolha pelo parto domiciliar, tanto que não comunicaram essa decisão. 
Nessa perspectiva, os relatos sugerem que o parto domiciliar planejado pode assumir um significado de "segredo". Assim, manter a decisão de não compartilhar com a família sobre a opção pelo tipo de parto pode ter sido gerador de algumas angústias para as participantes, mas também pode ter evitado outras, relacionadas aos julgamentos, preconceitos, medos, falta de informação, crenças e padrões culturais e familiares que poderiam ser confrontados e trazer implicações no vínculo familiar. Portanto, outra vertente de discussão a ser considerada, que talvez mais difícil do que falar sobre a escolha pelo parto domiciliar, seria ouvir a opinião do outro, principalmente da mãe. Nesse contexto, que compreende os enfrentamentos no processo do parto domiciliar planejado, pode-se pensar na dificuldade de um lugar de abertura para o diálogo entre as participantes e suas famílias, especialmente suas mães. Assim, na incerteza do posicionamento do outro, o silêncio se mostrou como uma opção, como uma proteção frente a ideia de ser invadida pelo outro.

Nesse sentido, Safra (2006) afirma que em uma relação dialógica há uma questão que é seguida por uma "resposta-questão" e assim sucessivamente, dessa forma, as experiências aparecem como fluxo. Mas segundo o autor, para que a experiência possa fluir é necessário que haja um lugar de abertura, sustentado inicialmente pelo holding e que depois o apoio desse percurso se dá pela presença do outro e em seguida, a abertura ontológica. Portanto, compreendendo que o bebê não chega apenas para o casal, mas para toda a família, há de se considerar que o compartilhamento ou não da experiência do parto pode gerar impactos na relação familiar. Segundo Safra (2004) a maternidade e a paternidade são constituídas por processos transgeracionais, uma vez que a mãe e o pai são pessoas em quem as questões familiares fundamentais se apresentam ao bebê.

Diferente de Violeta e Bromélia que não compartilharam com nenhum familiar sobre o parto, os relatos a seguir apontam que Amarílis e Gérbera escolheram alguns familiares para contar sobre a decisão de realizar um parto domiciliar:

[...] a gente decidiu não contar para a família porque os pais do Danilo são médicos e a minha sogra é muito neura assim e preocupada e ela ia me infernizar. Eu não queria ninguém questionando, dizendo que se acontecesse alguma coisa a culpa é minha. Eu queria, eu já estava, eu já tinha tomado uma decisão que para mim nunca tinha imaginado tomar e eu não queria ninguém vindo com coisas negativas assim. Então só eu e ele sabíamos e alguns amigos. [...] então a minha mãe não sabia, eu falava que havia esta possibilidade porque eu também não queria que ela passasse a preocupação dela para mim. Eu queria ficar muito calma assim, não queria ansiedade de ninguém em cima de mim, já bastava a minha sabe. [...] ela (mãe) assustou, ela falou: "você tem certeza? Eu sei o que você passou no parto da 
Bruna (primeira filha nascida de parto normal hospitalar), você me contou, mas não tem como fazer no hospital"? Eu falei: "mãe eu não quero pisar no hospital, eu tive o aborto, eu tive a Bruna que foi bem difícil para mim, não me sinto mais confortável num hospital, eu vou ver". Falei assim sabe: "eu vou ver", tipo deixei no ar assim sabe. E para a minha avó paterna também acabei falando porque ela teve os filhos dela em casa, mas só para a minha avó. Materna não, porque ela fala demais, ia contar para a família inteira. [...] ah ela (avó paterna) não ficou assustada, ela começou a contar dos partos dela e tem uma assistência assim né. Na época dela era a parteira, assim, as parteiras hoje em dia são as parteiras do parto planejado, que são enfermeiras obstetras, obstetrizes né. Na época dela não, era ali a parteira e depois acho, vem o médico ver ela, mas vem depois, tal, não tinha uma formação a parteira. E ela teve com as parteiras, então para ela, ela ficou tranquila assim: "não, vai dar tudo certo", não sei o que, "eu tive quatro né, eu tive em casa né", não sei o que. Então ela me deu a maior força assim. Então só, mais ninguém, ninguém sabia. Assim, depois foi até um choque, porque ficaram até meio sentidos assim. [...] então foi bem delicado assim, mas tudo bem, o Júnior já tinha nascido né. Então eles ficaram bem depois, mas foi um choque assim. (Amarílis)

Eu fiquei com receio de falar pros meus pais, pros meus sogros, eu não falei nem pro meu irmão, só pra minha irmã. Receio deles terem medo por ser em casa. A minha mãe, pra você ter uma ideia, nasceu ela e os 10 irmãos dela, nasceram tudo em casa. Na verdade era na roça, era em fazenda, mas ela tinha preocupações quanto a isso. Ela sabia do meu envolvimento com tudo isso, então nas conversas, o papo era sempre: "mas ah, hoje é hospital, hoje é mais seguro, ah, aquela época era parteira, ah tinha alguns imprevistos". Ai sempre vem né: "ah o fulano morreu logo que nasceu, ah é tão perigoso". Em conversas né, de quando eu relatava coisas que eu tava acompanhando. Então eu sempre imaginei que eles iam ficar muito ansiosos, iam ficar com muito medo da hora que eu tivesse em trabalho de parto lá. Eu falei: "pra não me influenciar em nada, vai ser melhor que eles não saibam, pra eu conseguir ficar tranquila aqui em trabalho de parto, hora que nascer eu já aviso todo mundo e tudo bem". E engraçado que foi exatamente isso, a minha mãe e minha sogra falam: "ah, ainda bem que você não me falou, eu ia ficar tão tensa porque eu não ia saber se eu ia poder ir lá na sua casa, não sabia se ligava pra alguém”. Eu falei: "o melhor foi elas já saberem que nasceu”. E foi mais ou menos assim. (Gérbera)

Amarílis optou por não contar para a família sobre a escolha pelo parto domiciliar, com exceção de sua avó paterna, que já havia passado pela experiência de ter filhos em casa e acolheu a sua escolha. Nesse sentido, Winnicott (1957/2013) aponta a importância das histórias familiares e acrescenta que a família é fundamental na civilização, pois nossa cultura é representada pelo modo como organizamos nossas famílias. O relato de Amarílis sugere ainda, que mesmo sem a aprovação da mãe diante da escolha pelo parto domiciliar, ela buscava apoio frente aos próprios medos e do possível julgamento dos familiares, visto que ela não confirmou onde seria o parto.

Gérbera optou em não contar para sua família e a família do marido sobre o parto domiciliar, com exceção de sua irmã. Temia que seus familiares ficassem com medo e muito ansiosos e isso influenciasse seu trabalho de parto. Ela relata, que ainda que sua mãe tivesse 
nascido em casa, não considerava seguro para a filha ter um parto domiciliar. Nesse contexto, Safra (2008) refere que a memória transgeracional nos devolve às nossas raízes, pois favorece as relações referentes à questões essenciais do humano, uma vez que nos apresenta tradições, organizações simbólicas e mitológicas. Contudo, o autor afirma que atualmente, essa memória que registra a história constitutiva do homem está sendo perdida, mas deveria estar presente nos discursos familiares, em espaços públicos e obras culturais. Dessa maneira, conforme a memória constitutiva vai se fragmentando, o homem contemporâneo vai sofrendo as consequências nocivas desse fato.

Nessa perspectiva, os relatos de Amarílis e Gérbera sugerem que mesmo algumas mulheres da família tendo tido um parto domiciliar, essa experiência não garante o apoio para outras que escolhem esse tipo de parto. Cada família é atravessada por histórias, valores, tradições e crenças que vão construindo a memória transgeracional. Entretanto, há de se considerar também, que as famílias carregam consigo as vozes de uma sociedade imersa no discurso do modelo biomédico, conforme aponta Amarílis sobre a posição de sua mãe: "eu sei o que você passou no parto da Bruna (primeira filha nascida de parto normal hospitalar), você me contou, mas não tem como fazer no hospital"? [sic] e Gérbera sobre sua mãe: "mas ah, hoje é hospital, hoje é mais seguro, ah, aquela época era parteira" [sic]. Portanto, seguindo o pensamento de Safra (2008), a memória transgeracional pode ser fragmentada tendo em vista as transformações do contexto social e isso pode influenciar no posicionamento familiar diante da opção pelo parto domiciliar. Pode ser considerada ainda, que a memória das experiências de parto vividas por cada mulher da família, também pode ter influência nesse processo de apoio familiar.

Nesse contexto, os relatos a seguir referem que Begônia, Petúnia e Dália também escolheram algumas pessoas para compartilhar sobre a decisão do parto domiciliar e ainda, como as histórias familiares de parto influenciaram o posicionamento das famílias:

[...] a dele (família do marido) a gente não contou que ia ser parto domiciliar, a gente só contou depois, porque todo mundo queria que eu fizesse cesárea. A minha família, como a minha mãe teve parto normal e eles me respeitam bastante, ao contrário da família dele que não respeita muito ele e nem a mim assim, ninguém. Eu contei inicialmente para a minha mãe e ela por mais que teve normal, ela ficou morrendo de medo, ela queria ficar lá em casa o tempo inteiro e tudo o mais. A minha irmã que só quer cesárea me chamou de louca, que eu não poderia fazer aquilo. E para o meu irmão eu acabei não contando. A minha irmã mais nova me respeitou e falou: "olha, se você tá decidindo isso eu tenho certeza que vai ser melhor, então, o que você precisar a gente vai estar aqui", é mais equilibrada. Mas assim, a 
minha família até que aceitou bem, mas eu pedi para não contar pra ninguém por conta desta situação né, de todo mundo achar que a gente é louca e tudo mais. E aí para a família dele também a gente só contou depois. Até então eu ia ter, eu ia tentar um parto normal, para a família dele, no hospital, essa era a ideia. Aí depois, quando a gente contou que nasceu em casa, a mãe dele surtou. Ela tem 82 anos, então ela ficou: "meu Deus, poderia ter morrido". E ela teve uma das filhas dela no sítio porque estava chovendo e a parteira não chegou. [...] então assim, eu falo que é muito engraçado né, até as pessoas que tiveram um parto normal, que nem ela que teve um domiciliar, tudo bem que não foi planejado, mas foi um domiciliar, correu tudo bem, acha que o mais seguro é a cesárea. Acho que muito a mídia também influencia né. Mas quanto a contar para eles foi isso, de um lado não contamos e do outro contamos, algumas pessoas assustaram e me respeitaram, isso que importa. (Begônia)

[...] foi bem complicado. Eles respeitam minha escolha sempre né, independente de qual seja, mas pra eles foi bem difícil né, principalmente pra minha mãe que perdeu um filho, ela até hoje acredita que foi porque passou da hora. Hoje, depois de estudar bastante pra ter o meu, eu acredito que não, mas ela ficou com isso na cabeça, então, ela entrou em trabalho de parto, acabou tendo de fazer uma cesárea e nove dias depois ele morreu e ela culpa a espera. Então depois disso, ela descobriu duas gravidez que já agendou cesárea. Foi o primeiro filho dela e aí o meu parto já foi agendado quando ela descobriu que tava grávida de mim e o meu irmão também, pelo medo de passar da hora, entendeu? Então, essa espera e fazer em casa, pra ela foi a morte né. Então, mas ela respeitou. [...] logo que eu decidi eu já fui preparando (risos). Só que assim, eu não queria, eu não queria que ela soubesse quando eu entrei em trabalho de parto, pra ela não ficar sofrendo né. Então eu queria contar o mais tarde possivel pra ela, pra que ela não ficasse sofrendo, mas ela acabou descobrindo um pouco antes, cedo demais. E ai ela sofreu bastante! (Petúnia)

\begin{abstract}
Minha família tem históricos ruins de parto né. Então, no começo minha mãe achou que era loucura, que os bebês da minha família são muito grandes. O meu segundo filho nasceu com quatro quilos (cesárea decorrente de transferência de parto domiciliar). E a minha vó perdeu bebês grandes no parto, a minha mãe teve uma desproporção no segundo filho. Nós somos uma família de pequenas mulheres e bebês grandes. E acabou contaminando essas histórias, acabou contaminando as histórias da família, tanto que em 60 anos, meu parto foi o primeiro parto normal, juntando todas as minhas tias, primas, irmãs, todo mundo, minha mãe. Mas assim, minha mãe sempre me respeitou, até mesmo porque eu nunca dei muita abertura né, era e pronto acabou. Minha mãe às vezes me ligava chorando, mas também sempre conduzi isso com muita tranquilidade. Não tive assim muita coisa. Claro que na hora eu não avisei ela que eu tava em trabalho de parto (risos) se não ela ia baixar lá em casa. Mas eu acho que por ser da área, o pessoal confiou bastante assim, que eu não ia me colocar em risco por causa de um capricho de ter um parto em casa né. A família do meu marido tem históricos bons de parto, então né, foi super tranquilo assim, com a família dele. Minha sogra teve dois partos normais, num tive problema. A família não foi problema. Então pra mim foi mais tranquilo porque eu não tive problema de lado nenhum. Marido que apoia, minha família não apoiava, mas também não ia contra, a família do meu marido apoiava, então, deu tudo certo. (Dália)
\end{abstract}

Os relatos de Begônia, Petúnia e Dália apontam que os sentidos atribuídos às experiências de partos das famílias, influenciaram o posicionamento dos familiares em relação ao tipo de parto escolhido pelas participantes. Begônia fez a opção de contar sua escolha de parto apenas para sua família, por se sentir mais respeitada do que na família do 
marido. Ainda assim, enfrentou algumas críticas e julgamentos. Ela relata que precisou enfrentar o medo e a angústia de sua mãe, mesmo esta já tendo a vivência de um parto normal. Para Petúnia, outras dificuldades se apresentaram, visto que sua mãe já havia passado por uma experiência de parto traumática. Mesmo se sentindo respeitada por sua família, Petúnia tinha o receio de que sua escolha pudesse causar sofrimento em sua mãe e queria protegê-la. Dessa forma, ainda que se sentissem respeitadas, havia uma preocupação e cuidado das participantes, na relação com suas mães. Nessa perspectiva, Winnicott (1960/2013) esclarece que em última instância, as experiências da vida do indivíduo se relacionam com seus pais. $\mathrm{O}$ autor refere que há um afastamento apenas em relação às figuras externas dos pais, visto que estes permanecem vivos na realidade psíquica do indivíduo, que sempre volta aos pais, especialmente a relação com a mãe. Assim, compreende-se que mesmo na vida adulta, a presença simbólica dos pais permanece. Portanto, pode-se pensar no impacto que o posicionamento da mulher, diante de compartilhar ou não sobre a decisão do parto domiciliar pode provocar na relação com seus pais.

A escolha de Dália por ter seu filho em casa, assim como Violeta, rompeu com as tradições familiares de parto. Em seu relato, Dália faz referências às histórias de parto tanto de sua família quanto de seu marido, sendo que ambas sabiam de sua decisão pelo parto domiciliar. Segundo ela, os históricos familiares de parto podem influenciar no apoio ou na falta do mesmo, diante da escolha pelo tipo de parto. Nesse sentido, Gutfriend (2010) refere que o processo de se tornar mãe e pai, inclui a história de seus próprios pais, pois nossa história é marcada pelo olhar do outro. Safra (2004) esclarece que "compreender o ser humano como singularização da vida de muitos implica em dizer que cada ser humano é a singularização da vida de seus ancestrais e é o pressentimento daqueles que virão" (p. 43). Segundo o autor, o ser humano nasce afetado pela história de seus ancestrais, pelo encontro com os contemporâneos e por aqueles que virão. Dessa forma, o sentido de si é transgeracional, pois vem de uma história em direção ao futuro. Safra (2006) acrescenta que "há uma polifonia na consciência humana, na fala humana, no modo de ser humano" (p. 95), uma vez que uma questão individual também atravessa a história da família. Portanto, compreende-se que as histórias familiares de parto, assim como a maneira que a gestante se posiciona diante da família sobre o processo de parto, pode trazer consequências nas relações familiares.

Os relatos de Mimosa e Tulipa referem que elas dividiram com alguns familiares sobre a decisão de ter um filho em casa e de maneiras diferentes, receberam ajuda no parto: 
Eu não queria falar para ninguém, não queria que ninguém soubesse, só quem sabia era minha sogra, minha cunhada também sabia e só, a gente não falava sobre o assunto. [...] porque eu não queria preocupar eles né. Minha mãe sabia que eu não queria no (nome da maternidade particular) e que eu queria fazer, eu falava sempre que queria fazer na (nome do hospital que atende SUS e particular), que era meu plano B, mas na verdade, queria domiciliar. Eu não queria ter o stress de ter que lidar com comentário, com gente querendo me fazer mudar de ideia, com eles também ficarem com medo. [...] acordei as quatro da manhã com a minha sogra chegando porque a minha sogra é enfermeira, então a gente combinou que ela ia poder estar junto no parto. [...] eu só avisei que ela tinha nascido, uma hora depois do nascimento, que a gente avisou. Aí ela (mãe) foi pra lá, para também não ficar o trabalho de parto inteiro estressado e também deixando a gente nervoso no processo. Então eu não quis falar. (Mimosa)

[...] com a minha mãe eu acho que, dos processos do parto domiciliar, eu acho que a minha mãe foi um ponto delicado da história, mas também foi uma superação na nossa relação. Porque quando eu já estava gravidona, de barrigona, toda vez ela vinha e falava: "e ai e o médico"? "Não, tá tudo bem, fica tranquila". [...] ela não sabia e ela falava: "mas você vai ter onde"? Eu falava: "no (nome da maternidade particular) eu não vou ter". Aí, já com umas 34 semanas ou 35 semanas de gestação, as enfermeiras obstetras foram lá em casa e tocaram nesse assunto, porque pra mim até então estava bem debaixo do pano né, eu não queria, talvez eu, se a gente não tivesse conversado sobre isso provavelmente eu teria escondido. [...] porque eu tinha medo do medo dela né. [...] ela trabalha na área da saúde, então todas as desgraças possíveis ela sabe né. Então eu ficava com medo dela ficar muito com medo e não conseguir me ajudar minimamente com o que fosse. Mas aí teve um dia que falei: "mãe a gente precisa conversar [...] a Teresa (terceira filha) vai nascer em casa". "Você é louca, porque eu sabia que você estava inventando alguma coisa". E aí a gente começou a conversar, falei: "mãe o lugar que eu me sinto segura é na minha casa, as enfermeiras obstetras são a melhor coisa que existe, todos os partos que eu atendi (como doula) até hoje tinham umas e foram elas que conduziram tudo com segurança, com tranquilidade. Você vai conhecê-las, vai tirar suas dúvidas". [...] então, nisso ela foi acalmando, ficando mais tranquila e a gente conversou e na hora ela falou: "não... eu preciso de um tempo para pensar". E ai eu peguei uma cartilha né, com os trabalhos científicos de parto domiciliar e entreguei na mão dela. [...] e aí, a partir deste dia acho que ela foi gestando a própria ideia do parto domiciliar e hoje ela é uma que levanta bandeira né [...] então ela não virou uma ativista, ela virou uma propagandista de coisas boas. E ela foi uma super, nossa ela foi o meu apoio. [...] olha pra conversar com a minha mãe eu precisei me empoderar muito, muito mais tecnicamente dos processos porque meu coração já dizia do parto domiciliar, eu sabia dos perigos, dos riscos, das vantagens e das desvantagens enfim. Mas eu precisei firmar dentro de mim e ser muito serena com a minha mãe porque eu sou muito impulsiva, eu falo, eu brigo, eu choro. [...] eu falei: "olha eu não estou, não vim pedir a sua opinião, eu vim te comunicar minha decisão e eu gostaria muito que você estivesse ao meu lado, porque você para mim é uma parte essencial. Eu quero que você fique com as minhas filhas para eu ficar tranquila, mas isso não está, a decisão do parto em casa, não está nesta conversa, ela já foi decidida e eu quero que você seja minha aliada neste processo todo. Eu quero ter você como minha amiga, como companheira". (Tulipa)

A princípio, Mimosa não queria compartilhar sua decisão pelo parto domiciliar por receio dos julgamentos e medos dos familiares, intuindo que isso poderia influenciar seu trabalho de parto. O relato de Mimosa repete o discurso de outras participantes, uma vez que traz consigo o medo de ser invadida e dominada pelos julgamentos e o medo de ser 
contaminada pelo medo do outro. Contudo, pelo fato de sua sogra ser enfermeira, Mimosa resolveu contar, para que ela pudesse ajudá-la no parto. A fala da participante sugere que, ao escolher para quem contar sobre a decisão pelo parto domiciliar, a mulher está buscando apoio para minimizar suas angústias frente aos enfrentamentos experimentados por esse tipo de parto.

O relato de Tulipa aponta que mesmo diante da decisão já firmada sobre o parto domiciliar foi preciso um enfrentamento em relação aos familiares, que resultou em um empoderamento para não sucumbir aos próprios medos. A princípio, Tulipa pensou em não contar para sua mãe, porque "tinha medo do medo dela" [sic]. Sobre os medos, Winnicott (1957/2016) refere que na gestação, parto e nos primeiros meses de vida, há uma dependência absoluta do bebê para com uma mãe e dessa maneira, todo indivíduo tem um "débito infinito" com uma mulher. $\mathrm{O}$ autor aponta que não se trata de gratidão, mas de um reconhecimento dessa mãe devotada, que assim, promove a diminuição do medo da dependência, que pode se manifestar por medo de uma mulher ou outras formas mais difíceis de reconhecer. Contudo, sempre inclui o medo da dominação.

Nesse sentido, o relato de Tulipa sugere que ela estava vulnerável, com medo de ser dominada pelo medo da mãe. Pode-se pensar que houve uma fantasia de antecipação por parte de Tulipa, sobre a reação que sua mãe teria quando ela confirmasse onde seria seu parto, uma vez que a mãe já intuía isso. A fala de Tulipa aponta que a escolha por ter a filha em casa poderia ser compreendida por sua mãe, como sendo geradora de alguma "desgraça": "ela trabalha na área da saúde, então todas as desgraças possíveis ela sabe né” [sic]. Ainda assim, houve um "lugar de abertura" (Safra, 2006) na relação de Tulipa com sua mãe, permeado por um diálogo e acolhimento que gerou uma "superação" [sic] na relação entre mãe e filha. De acordo com o relato, a mãe de Tulipa precisou de um tempo para elaborar a escolha da filha, mantendo em fluxo esse lugar de abertura. Tanto que depois desse processo, a mãe da participante mudou seu posicionamento sobre o parto domiciliar: "a partir deste dia acho que ela foi gestando a própria ideia do parto domiciliar e hoje ela é uma que levanta bandeira né [...] então ela não virou uma ativista, ela virou uma propagandista de coisas boas" [sic]. Tulipa era uma filha que queria o apoio da mãe e ainda, uma mãe preocupada com o cuidado de suas duas filhas mais velhas durante seu parto domiciliar. Dessa maneira, Tulipa pode contar com o apoio e ajuda da mãe, inclusive para cuidar de suas filhas durante o parto. 
Entre as 17 participantes do presente estudo, apenas uma teve a mãe presente no momento do parto, como aponta o relato a seguir:

\begin{abstract}
Na verdade a minha mãe me apoiou a todo momento. Assim, eu acho que desde o primeiro parto (parto normal hospitalar), se eu falasse que eu queria parto domiciliar, ela ia ter me ajudado. Porque tinha o fator financeiro, mas eu falei, acho que eu não tinha nem estrutura psicológica, eu e meu marido né. A gente tinha acabado, assim, tava de um ano de namoro e eu fiquei grávida. Então eu falo assim, a minha mãe me apoiou todo o tempo. É... assim, meu pai como é separado da minha mãe, eu não falei com ele, acho que ele ficou sabendo depois que nasceu. O meu padrasto não tinha muita opinião. [...] minha sogra achava eu louca, ainda acha (risos). Mas também, ela num... num ficou assim, num chegou dar, a palpitar, vamos dizer assim, né. Então, eu já tinha o apoio da minha mãe e meu marido depois abraçou a causa. Então não tive muito problema quanto a isso, a parte da família. [...] (durante o parto) minha mãe tava do lado me dando a mão, [...] eu lembro que eu tava segurando a mão da minha mãe e da Maria (enfermeira) e meu marido filmando. [...] Ah... a presença da minha mãe, assim, nesse segundo parto, eu achei que ela ficou mais nervosa que no primeiro. Mas assim, num me atrapalhou né. É... e eu acho que foi uma hora que ela me deu bastante força, porque teve uma hora que eu falava assim: "gente eu não vou dar conta". Eu falava... eu tava muito cansada, eu falei: "eu tô muito cansada", eu falei. Aí eu ficava pensando: "meu Deus, eu quis tanto o parto em casa, agora eu vou desistir? Eu num posso desistir". Porque isso passava pela minha cabeça. Porque parece que a gente tá tão cansada. Eu falava: "nossa"! Ai minha mãe falava: "não, vamo lá, você dá conta, mais um pouco". [...] Então assim, foi assim, a hora que é a hora que mais lembro dela né, foi na hora do período expulsivo que eu lembro dela com a mão em mim né e ali me dando força: "vai, daqui a pouco o bebê chega, só mais uma contração". Então foi bom. (Alfazema)
\end{abstract}

De acordo com o relato de Alfazema, ela recebeu apoio e contou com a presença de sua mãe no nascimento de seus dois filhos, tanto no parto normal hospitalar de sua primeira filha, quanto no domiciliar de seu filho. A fala da participante revela que ela compartilhou sobre a decisão do parto domiciliar com seus familiares mais próximos. Pode-se considerar que ao receber o apoio da mãe diante da escolha pelo tipo de parto, Alfazema se sentiu mais segura para dividir sua decisão com outros familiares, ainda que recebesse algumas críticas e julgamentos: "minha sogra achava eu louca, ainda acha" [sic].

Nesse contexto, compreende-se que contar com o apoio da mãe, assim como sua presença no momento do parto, foi encorajador e significativo para Alfazema. Segundo a participante, próximo ao momento expulsivo, ela estava muito cansada e temia desistir: "gente eu não vou dar conta" [sic]. Mas a presença e as palavras da mãe: “não, vamo lá, você dá conta, mais um pouco" [sic], ajudaram Alfazema a enfrentar as situações e a se 
manter na decisão de ter seu filho em casa. A esse despeito, Lovo (2009) refere que a relação mãe e filha é fundamental nos momentos importantes do ciclo biológico da mulher, pois a partir de processos de identificação com a mãe, ela poderá se sentir mais segura ou não, no enfrentamento dessas experiências, principalmente no nascimento de um filho.

Sobre o posicionamento das participantes quanto a realizar um parto em casa, algumas não compartilharam com as famílias sobre essa decisão. Segundo os relatos, enfrentar os possíveis medos e julgamentos dos familiares, parecia ser desorganizador e poderia interferir no processo do parto. O medo e angústia que essa escolha poderia causar nos familiares, também foi um fator que contribuiu para que algumas mulheres mantivessem em "segredo" a decisão de ter um filho em casa. Contudo, os relatos sugerem que manter "segredo" sobre o parto domiciliar planejado também foi uma forma de evitar outros medos, angústias e enfrentamentos e assim, preservar o vínculo familiar.

Nessa perspectiva, vale ressaltar que a possibilidade de compartilhar com os familiares, especialmente com a mãe, sobre a escolha pelo parto domiciliar pode contribuir para que os enfrentamentos do processo de parto sejam menos sofridos para a gestante do ponto de vista emocional, compreendendo que manter essa decisão em "segredo" impõe outros sofrimentos. Segundo Lobo (2008) os medos mais comuns da gestação estão relacionados às dificuldades da gravidez, a história do casal, ao desejo em relação ao filho e também a maneira como a mãe da gestante contou a ela sobre seu próprio nascimento. Portanto, segundo a autora, uma identificação materna positiva é importante para que a gestante consiga elaborar as experiências conflituosas primitivas que podem ser revividas nesse momento. Nesse contexto, a autora acrescenta que a maneira como a gestante foi cuidada por sua mãe pode ser determinante para que ela encontre recursos internos para desempenhar a maternidade.

As participantes que compartilharam sua escolha, o fizeram no sentido de comunicar uma decisão já firmada. Mesmo nas famílias que haviam histórias de parto em casa, algumas foram contrárias a essa escolha. Apenas uma participante contou com a presença da mãe durante o parto. Os relatos sugerem que, ainda parece haver pouca compreensão dos familiares sobre a escolha de realizar um parto em casa, abdicando das tecnologias hospitalares. Nesse sentido, o parto domiciliar planejado ainda encontra resistência de ser aceito socialmente e pode ser visto como algo transgressor e subversivo, que pode colocar em risco a parturiente e o bebê. 


\subsubsection{Sentidos do parto domiciliar planejado}

Essa categoria aborda os múltiplos sentidos do parto domiciliar planejado relacionados ao processo do parto, a partir da análise das entrevistas realizadas com as participantes. Ela foi dividida em três subcategorias, a saber: Parto controle, Parto romântico e idealizado, Parto poder.

\subsubsection{Parto controle}

Essa subcategoria agrega os conteúdos que referem o desejo ou a necessidade de controle de algumas participantes durante o processo do parto domiciliar planejado, desde a preparação até o pós-parto.

Os relatos de Lavanda e Mimosa apontam que ambas realizaram um plano de parto visando organizar, registrar e comunicar suas escolhas referentes ao parto domiciliar. Ressalta-se que o plano de parto é um documento recomendado pela OMS, garantido pela legislação brasileira (Lei $\left.\mathrm{n}^{\circ} .15 .759,2015\right)$ e tem o objetivo de proporcionar uma melhor qualidade na assistência ao parto. Nele, a gestante registra seus desejos em relação ao trabalho de parto e parto, incluindo os procedimentos realizados pela equipe que a assiste e os cuidados com o bebê no pós-parto imediato. Dessa forma, o plano de parto pode ser utilizado tanto para partos hospitalares quanto para domiciliares, compreendendo que quando é pensado para o contexto domiciliar há maior liberdade de escolhas quanto aos procedimentos e rituais que envolvem o parto.

Os relatos a seguir, ressaltam como Lavanda e Mimosa perceberam a construção do plano de parto e os sentidos que carregavam os mesmos:

[...] fiz um plano de parto individualizado, focado no meu projeto, no meu plano de ter um parto domiciliar. Então isso foi muito bom não só, eu não via aquele documento como uma não violência obstétrica, mas uma coisa na qual eu construi, porque eu pensava: "eu preciso estar pronta para parir". Então eu queria um documento que eu tivesse pensado tudo antes né, toda logística, eu tinha um filho já, queria que ele participasse, teria que ter gente para ficar com ele. A casa precisaria tá né, tudo pensado, toda questão logística para que, na hora do parto eu tivesse tranquila para parir. [...] então quando é na sua casa, você tem que pensar nisso tudo antes né. Então esse plano de parto me ajudou muito a pensar em toda a logística que envolvia propriamente o parto e que circundava o parto, para que eu pudesse naquele momento do parto, estar comigo mesma. [...] e como eu tinha dito, eu tinha feito um plano de parto pra toda logística que deveria acontecer junto com o parto, com meu filho. Tudo deu certo também, porque eu tinha afinado muito também com babá, com todo mundo, 
com a portaria do prédio. Então ninguém ligou, ninguém atrapalhou, foi sensacional, tudo deu muito certo. Então toda parte logística, eu já tinha pensado antes, na hora de parir eu tava comigo mesma. Meu companheiro também tava afinado, sabia ali, o que ele devia falar, o que devia fazer, muito respeitoso, muito carinhoso, muito amoroso. As enfermeiras respeitaram meu espaço, super tranquilas, ninguém afobado, então assim... foi sensacional! (Lavanda)

[...] as doulas chegaram as 7:00 e pediram para fazer um toque e no meu plano de parto eu tinha colocado que eu não queria saber de nada que estava acontecendo no parto. [...] eu não queria saber de nada da evolução do trabalho de parto e que se eu precisasse ser removida pra algum lugar, se desse algum problema, era também para conversar com o meu marido. Se qualquer assim, eu não queria estar muito ciente, eu queria estar só sentindo o processo, porque como eu sou muito, que eu tinha te falado o problema de querer controlar as coisas, eu não queria estar no campo mental, não queria racionalizar as coisas, só queria viver o processo. Não queria tomar nenhuma decisão prática, lógico, eles sabiam do que eu queria, tanto o meu marido quanto elas, então eles sabiam o que que eu queria fazer, então não precisava de ficar me comunicando. Me deixasse só ser bicho, viver o processo. (Mimosa)

Lavanda, que já havia passado por um parto normal hospitalar, em que se sentiu desrespeitada, relata que queria "estar pronta para parir" [sic] em casa e que no momento do parto queria estar "consigo mesma". Para isso, fez um plano de parto detalhado para cuidar de toda a logística que envolvesse o nascimento de seu filho. Nessa perspectiva, pode-se pensar que ao planejar e cuidar dos detalhes do parto, Lavanda, assim como outras participantes do presente estudo, estava se responsabilizando por questões específicas do parto domiciliar, mas que são de competência da gestão hospitalar quando o parto é realizado nesse ambiente. Mimosa, que também fez um plano de parto aponta que queria sentir esse processo de maneira mais instintiva, "só ser bicho" [sic], sem tentar racionalizar o momento do parto ou controlar as coisas.

Nesse contexto, considera-se que o desejo de Lavanda e Mimosa era estar em maior contato com o próprio corpo e suas emoções durante o parto. A esse despeito, Ferigato, Silva e Ambrosio (2018) referem que a maternidade, incluindo o momento do parto, produz sentidos singulares para as mulheres, pois é um processo que gera transformações psíquicas, corporais e ocupacionais e exige adaptações afetivas, sociais, familiares, econômicas e estruturais. Dessa maneira, a maternidade compõe uma experiência corporal, cultural e social. As autoras apontam que para cada mulher, o corpo é um "território cultural" e singular, pois é através dele que nos comunicamos e relacionamos com o mundo, produzindo nossa própria existência. As autoras acrescentam que o corpo não é apenas um organismo, uma vez que nele se produz subjetividade, cultura e sociedade. 
Nessa perspectiva, compreende-se que estar em contato com o corpo, também significou entrar em contato com a dor do parto sem analgesia e como dito anteriormente, isso representava um dos maiores medos das participantes do presente estudo. Segundo Scarton et al. (2015), para grande parte das gestantes, o medo do parto está associado à dor, devido a uma visão cultural e social que é transmitida de geração em geração e acentuada pela mídia que retrata o parto como um momento de extrema dor e sofrimento. As autoras acrescentam que algumas gestantes temem não conseguirem parir não apenas pela dor do parto, mas também pelo medo e angústia do desconhecido, da vivência de algo que só era conhecido pelos relatos de outras pessoas. Assim, pode-se considerar que diante das expectativas do momento do parto, organizar e planejar os detalhes, num sentido de manter as coisas sob controle, foi uma das formas encontradas pelas participantes para minimizar suas angústias e medos, em um esforço para enfrentar os imprevistos.

Segundo Costa, Pacheco e Figueiredo (2012) durante a gestação, a mulher vai construindo expectativas em relação ao parto e que vão aumentando com a proximidade do nascimento do bebê. Embora possam ser expectativas positivas, envolvem preocupações, ansiedades, inseguranças e medos diante da experiência do parto e que podem ou não concretizar-se. As autoras referem que para grande parte das mulheres, a experiência do parto é compreendida como sendo difícil, uma vez que envolve ansiedade, dor, perda de controle e reações inesperadas. Portanto, nem sempre as expectativas acerca do parto são realistas, contrariando o que as mulheres imaginavam.

As expectativas de Lavanda e Mimosa eram de poder estar mais livres e intuitivas durante o parto. Contudo, independente das estratégias utilizadas, elas demonstraram a necessidade de assumir o controle dos acontecimentos e dos afetos. Lavanda afirma que para se sentir tranquila e segura precisou organizar e controlar tudo o que estava à sua volta, com o filho, a babá, o porteiro do prédio e o marido: "meu companheiro também tava afinado, sabia ali, o que ele devia falar, o que devia fazer" [sic]. Dessa maneira, percebe-se por um lado maior liberdade de escolhas decorrentes da opção por realizar um parto em casa e de outro, medos e angústias que contribuíram com o desejo de controle, o que incluía um direcionamento do cuidado oferecido pelo outro. Nessa perspectiva, Mimosa comenta que por ser muito controladora "não queria racionalizar as coisas, só queria viver o processo" [sic] e para isso orientou seu marido e a equipe de como deveriam se posicionar durante o parto. Seu relato revela que apesar de confiar nas pessoas que estavam a sua volta no momento do parto, 
com intuito de estar mais instintiva, Mimosa queria direcionar e controlar a situação na tentativa de lidar com suas inseguranças e com os possíveis imprevistos do parto.

Os relatos sugerem que havia uma ilusão de onipotência de controle como resposta à vulnerabilidade das participantes, frente à angústia do desconhecido e imprevisível momento do parto. Sobre a ilusão de onipotência, Winnicott (1962/2008, 1945/1993) refere que no início, o bebê que é totalmente dependente da mãe é "um ser imaturo que está continuamente a pique de sofrer uma ansiedade inimaginável” (1962/2008, p.56). Quando a mãe satisfaz suas necessidades e o alimenta, o bebê cria a ilusão de onipotência de que o cuidado e o seio que lhe são oferecidos, foram por ele concebidos e estão sobre seu controle onipotente. Dessa maneira, o bebê expressa sua criatividade primária, alivia sua angústia e acredita que está determinando os acontecimentos à sua volta.

Pode-se considerar assim, que frente às angústias e medos, emergiu a necessidade de controle onipotente que possibilitou enfrentar o momento do parto. Desse modo, as participantes buscavam proteção frente suas vulnerabilidades, especialmente as relacionadas ao parto domiciliar planejado, como o enfrentamento da dor sem analgesia e a responsabilização diante dos imprevistos que poderiam acontecer. Contudo, essa ilusão onipotente poderia tanto proteger as participantes, quanto provocar um afastamento de si mesmas, dificultando lidar com as inseguranças e contribuindo para aumentar a necessidade de controle.

Também foi possível identificar que a sensação de controle experimentada por algumas participantes não se restringiu apenas ao momento do parto, como destacam os relatos a seguir:

[...] é muito maravilhoso tipo assim, eu fiquei no meu ambiente o tempo inteiro, eu fiquei onde eu queria o tempo inteiro. A gente teve ele no nosso quarto que é o lugar mais íntimo da nossa casa né. Eu fiz o que eu queria, eu tive toda liberdade de fazer o que eu queria. Eu caminhei no condomínio, eu caminhei no meu quintal, a hora que eu queria comer eu comia, a hora que eu queria beber eu bebia. Eu acabei o parto, eu tomei um banho, eu fui jantar. A gente tinha preparado, eu tinha preparado uma torta por conta da contração, aí a gente foi jantar. Depois a gente descansou ali, tipo eu não precisei de trânsito, não precisei de recepção, eu não precisei de nada. Eu só precisei do que eu precisava mesmo, que é do meu canto, do meu lar, da minha energia né. (Begônia) 
[...] "você é louca". Sabe, eu sabia que ia ouvir isso, assim, então eu tinha que me fortalecer, assim. Às vezes, tem mães que, a Margarida (outra participante desse estudo) não está nem aí para o que vão falar. Ela vai falar: "foda-se", entendeu. Eu já tinha esta preocupação, eu sei que vão vir falar e eu não vou baixar a cabeça, eu tenho que falar: "não, eu escolhi isso por conta disso", eu tava certa disso. Não sei o que eu queria mostrar, porque eu queria que as pessoas se informassem sabe. Então eu tinha que me fortalecer para não me abalar, então eu acho que esse fortalecimento para o parto domiciliar, que eu não teria se eu tivesse tido no hospitalar, que todo mundo ia aceitar. É, eu acho que me ajudou também para me fortalecer ali como mãe e bancar o jeito que eu estava a fim de fazer sabe. "Ele vai mamar até a hora que eu quiser, ele vai dormir na minha cama até quando eu quiser" e eu tipo: "eu vou ter o parto domiciliar de novo se eu quiser", sabe assim (risos). Isso me ajudou assim, mas eu acho que o parto, às vezes dá uma influenciada para você ver né, que tipo... você vira um bicho ali e você tem os seus instintos ali, você reage a eles, é bem diferente de um médico falando o que você tem que fazer. (Amarílis)

Begônia relata que durante o parto e pós-parto imediato pôde fazer o que queria, pois estava em sua casa e dessa maneira, sentia que tinha liberdade e tudo o que precisava para ter seu filho: "eu só precisei do que eu precisava mesmo, que é do meu canto, do meu lar, da minha energia né” [sic]. Amarílis refere que por estar em casa sentiu que poderia ter mais autonomia e um controle maior sobre o parto e outros aspectos relacionados à maternidade, que provavelmente não seriam possíveis se estivesse no hospital: "é bem diferente de um médico falando o que você tem que fazer" [sic]. De acordo com os relatos, estar no ambiente doméstico favoreceu para que as participantes tivessem maior liberdade de escolhas e se sentissem mais seguras durante o parto e pós-parto. Pode-se pensar, em diálogo com Winnicott (1956/1993), que uma provisão ambiental suficientemente boa pode minimizar as ansiedades e angústias, facilitando assim, que o indivíduo alcance suas satisfações. Dessa forma, compreende-se que o ambiente escolhido e preparado pelas participantes era um lugar conhecido e acolhedor para a experiência do parto, o que minimizou suas angústias. Os relatos de Begônia e Amarílis sugerem ainda, uma ambivalência frente ao cuidado do outro, que hora pode ser compreendida como uma invasão, hora como necessidade de proteção.

Nesse sentido, segundo Prates et al. (2018) o ambiente doméstico é um lugar seguro para vivência do parto. A experiência de ter um filho em casa representa o renascimento do processo de parto, pois é um evento íntimo que acontece num lugar acolhedor ao modo de viver da família. As autoras apontam que no parto domiciliar há uma retomada do protagonismo, uma vez que a mulher resgata para si, o próprio parto e o controle do corpo mediante sua liberdade de escolhas. Nesse contexto, Costa et al. (2012) referem que no pósparto, grande parte das mulheres sente maior capacidade de controle, confiança e prazer do que no momento do parto, mas não deixam de sentir medo. 
Através da análise das entrevistas compreende-se que o desejo e a necessidade de controle experimentado pelas participantes podem estar atrelados aos enfrentamentos das especificidades do parto domiciliar planejado. Dessa forma, é um controle que foi conquistado mediante aos enfrentamentos e o cuidado com as responsabilidades que o parto domiciliar planejado carrega. Nesse sentido, Amarílis comenta que precisou se fortalecer para enfrentar as críticas que receberia por optar por um parto domiciliar e isso a ajudou se posicionar para ter o controle e fazer as coisas da maneira como desejasse, tanto no parto quanto no pós-parto: "ele vai mamar até a hora que eu quiser, ele vai dormir na minha cama até quando eu quiser" e eu tipo "eu vou ter o parto domiciliar de novo se eu quiser" [sic].

De acordo com os relatos, as participantes apontam que gostariam de estar menos controladoras e mais intuitivas durante o parto. Mas para isso, precisaram sentir que tinham o controle do que estava à sua volta, tanto dos acontecimentos, quanto dos afetos. Considera-se que essa necessidade de controle experimentada pelas participantes foi uma forma de proteção conquistada pelos enfrentamentos do processo do parto domiciliar planejado, para que não se sentissem invadidas e controladas pelo outro.

\subsubsection{Parto romântico e idealizado}

Essa subcategoria aborda como algumas participantes desejaram e idealizaram um modelo de parto domiciliar de forma romantizada, e como a mídia pode ter influenciado nesse processo.

Sobre o termo "romântico", Ribeiro (2010) refere que possui uma vasta história sobre sua origem. Contudo, ele ressurge no século XVIII com outro sentido, para expressar aquilo que desperta o sonho, a fantasia, a imaginação e mobiliza a alma; como os amores trágicos e ideais utópicos. O Romantismo, enquanto movimento filosófico, artístico, literário e político surgiu na Europa em oposição ao Racionalismo, numa época em que o ambiente intelectual era de grande rebeldia. As principais características do Romantismo eram o individualismo, a subjetividade, idealização e sentimentalismo exagerado. Nesse contexto, através da análise de conteúdo das entrevistas foi possível identificar alguns elementos do Romantismo relacionados à fantasia, imaginação e idealização e foi nessa perspectiva, que o termo "romântico" foi utilizado para o presente estudo. 
A seguir, Amarílis e Alfazema relatam sobre suas expectativas e acontecimentos no momento do parto:

[...] a doula me mostrou depois esta gravação e na hora estava só ela e o Danilo (marido) lá. Eu de pé, acabei de sair do banheiro, do chuveiro e tinha planejado música, vela sabe, um monte de coisas assim, tudo tipo, nossa idealizado, aquele parto que a gente... aqueles romântico que a gente vê nos vídeos, assim sabe, com musiquinha, nanannaã. E aí eu saí de lá fazendo força. Aí veio a Lia (doula) e falou que tem que ir pra cama, eu falei: "não consigo". E aí ela falou: "não... mas espera aí, no intervalo da contração a gente te ajuda". Aí veio o intervalo da contração e ela me botou de quatro apoios, colocou umas almofadas pra eu me apoiar assim. "O Júnior tá vindo muito rápido, eu tô com medo de lacerar a episiotomia... que estava com trauma da episiotomia (do parto normal hospitalar de sua primeira filha). [...] eu tentando controlar, aí veio a cabeça e eu segurei a cabecinha dele com minha mão. E aí eu falei: "ele tá vindo muito rápido e eu quero devagar, vai arrebentar tudo", não sei o que. Aí eu falei: "quer saber gente, o moleque tá querendo nascer e eu tô segurando aqui". Eu respirei fundo e falei: "vem Júnior, pode vir". Ai veio a contração e ele nasceu. Ele veio com um olhão arregalado, até mostro a foto assim. Aí eu peguei ele e ele olhou pra mim com aquele olhão dele assim. Aí eu cantei uma música pra ele [...] e todo mundo começou a cantar a música junto comigo. Ai foi lindo! Vou começar a chorar... (Amarílis)

$E$ É tem algumas coisas assim que a gente fala: "nossa", a gente idealiza né. Eu queria que minha filha tivesse perto. Uma das coisas que eu queria, que fosse na banqueta e meio que eu que pegasse (risos). E na verdade acabou que eu entrei na banheira e não consegui sair da banheira. Então não foi na banqueta, foi na banheira. E foi assim, eu acabei ficando de quatro apoios e não foi eu que peguei meu filho né, a enfermeira que pegou, mas logo eu já peguei (risos). Mas eu falo, tudo a gente começa a idealizar, idealizar e na hora também não sai assim perfeito. Mas de resto assim, não tem... lembrança ruim. Mas de resto foi tudo mais ou menos como eu queria. (Alfazema)

Como dito anteriormente, todas as participantes se prepararam para o parto domiciliar. Por meio de grupos presenciais e virtuais, com profissionais qualificados, com outras mulheres e juntamente com seus companheiros, elas se apropriaram de informações científicas sobre o processo fisiológico da gestação e do parto. Nesses mesmos espaços, as participantes também tiveram a oportunidade de entrar em contato com conteúdos que podem ter favorecido a fantasia e idealização para o momento do parto. Nesse contexto, Oliveira (2014) refere que os grupos de apoio às gestantes e mães são fundamentais no processo de elaboração dos significados da maternidade, visto que socializar e partilhar experiências é significativo para essas mulheres.

Segundo Winnicott (1935-1945/1993) a fantasia é importante para o desenvolvimento emocional de todo ser humano, uma vez que o indivíduo chega à realidade externa através das 
fantasias onipotentes que são elaboradas com o intuito de fugir da realidade interna. O autor aponta que a fantasia é pessoal e organizada e se relaciona historicamente com as experiências, excitações, prazeres e dores desde a infância. "A fantasia é mais primária que a realidade" (1945/1993, p. 280), é um esforço criado pelo indivíduo para lidar com a realidade interna e não com as frustrações da realidade externa. Ainda que o autor se refira aos momentos iniciais do desenvolvimento humano, seu pensamento se estende à vida adulta. Plastino (2018), fundamentado pelo conceito de Winnicott, refere que a fantasia é "anterior a realidade", uma vez que a realidade não pode ser compreendida como uma projeção do sujeito, mas sim, é mediada pela fantasia.

De acordo com Szejer (1999) “o recém-nascido já nasceu antes de nascer” (p. 55). Assim, pode-se pensar que fantasiar um parto romântico foi uma das formas de proteção para as participantes, uma vez que a fantasia pode ter contribuído para construção da realidade do parto, no sentido de ajuda-las a enfrentar a realidade interna, com seus medos e angústias diante do desconhecido e imprevisível. Nesse sentido, Segal (2005) aponta que as fantasias são motivadas por nossos desejos e necessidades e que determinam nosso interesse pelas coisas, nossas convicções, suposições, percepções e atitudes. Segundo a autora, por trás de qualquer crença, suposição, pensamento, atitude e relacionamento, há sempre uma fantasia. Ela acrescenta que as fantasias nos ajudam a enfrentar angústias e conflitos, tanto internos quanto externos. Contudo, a autora alerta que as fantasias também podem ser uma forma destrutiva de negar a realidade.

Nesse contexto, considera-se que entrar em contato com imagens de partos domiciliares planejados e pessoas ligadas a essa prática, contribuiu para que as participantes fantasiassem e idealizassem o próprio parto, reafirmando a escolha por ter um filho em casa. Sobre a idealização, Mijolla-Mellor (2002) esclarece que é um mecanismo de defesa que promove uma ilusão sobre a realidade tanto do sujeito que idealiza, quanto àqueles que o cercam. A fala de Amarílis: "aí eu cantei uma música pra ele [...] e todo mundo começou a cantar a música junto comigo. Ai foi lindo! Vou começar a chorar..." [sic], exemplifica essa definição e aponta a importância do holding de pessoas envolvidas no processo do parto domiciliar; uma vez que esse tipo de parto carrega consigo características específicas, como o enfrentamento da dor sem analgesia, o posicionamento com a família, entre outros. Temas que foram abordados nas categorias anteriores. 
Nessa perspectiva, Feyer, Monticelli, Boehs et al. (2013) referem que o nascimento de um filho em casa é bem diferente de um nascimento no hospital, pois em casa há a possibilidade de organizar o ambiente como um "ninho", com mais liberdade de escolhas para a chegada do bebê no momento do parto. Segundo as autoras, o casal que opta por ter um filho em casa, o faz não apenas como uma nova maneira de experenciar o nascimento, mas sim como um ritual de passagem, uma forma de celebração à vida e à família. É um ritual de passagem para o momento de "separação", onde a mulher se tornará mãe, o homem pai e o que está chegando, se tornará filho. Nesse contexto, os rituais de cuidado, ou seja, as práticas simbólicas envolvidas no parto domiciliar planejado podem ajudar no enfrentamento para esse momento desconhecido. As autoras acrescentam que para algumas famílias, a casa se apresenta como um lugar sagrado, daí a presença de objetos como velas, flores, incensos, imagens religiosas etc.

Pelos relatos apresentados, as participantes demonstraram o desejo de ritualizar o parto, como afirma Amarílis: "tinha planejado música, vela sabe, um monte de coisas assim" [sic] e também o desejo de acolher o filho ao nascer, como no caso de Alfazema: "uma das coisas que eu queria, que fosse na banqueta e meio que eu que pegasse" [sic]. De acordo com Porte (2005), os ritos e rituais são estudados desde a Antiguidade por diversas abordagens como a filosofia, a antropologia, etnologia e sociologia, o que dificulta uma definição única. Contudo, o autor considera os ritos e rituais como uma ação ou conjunto de ações individuais ou coletivas, que são ritmadas, ordenadas e obrigatórias, que se repetem nos detalhes e que também podem se relacionar com o sagrado. Cavalcanti (2018) acrescenta que na tradição antropológica a noção de ritual busca a compreensão da natureza simbólica da ação humana, incluindo aspectos sociais e culturais. Segundo o autor, os rituais são agregados simbólicos de condutas, experiências e ações que articulam, desarticulam e rearticulam elementos da experiência social apreendida sob vários ângulos. Assim, compreende-se que as participantes criaram rituais para o momento do parto, com o intuito de realizar e compartilhar seus desejos e fantasias com aqueles que estavam ao seu lado.

Sobre o desejo de idealizar e ritualizar o momento do parto, Rosa comenta:

[...] os dois nasceram no mesmo lugar (risos). Muito engraçado, porque no parto dele (primeiro filho), eu já tava na banheira e a gente sempre vê aqueles vídeos e tem aquela imagem de que vai nascer na banheira né e foi o lugar que menos eu me senti confortável. Eu me senti super desconfortável na banheira, chegou um ponto que eu falei: "não gente, não tá 
dando, minha perna tá doendo, não tô achando posição. Eu quero sentar. Aí foi quando elas (enfermeiras) deram a ideia: "vai relaxar um pouco debaixo da ducha, vai sentar na banqueta". E foi o lugar que me senti mais confortável. Então foi lá que eu fiquei. E aí foi isso e aí ele nasceu." (Rosa)

Rosa relata que idealizava o nascimento de seu filho dentro da banheira, da mesma maneira como ela via nos vídeos: "eu já tava na banheira e a gente sempre vê aqueles vídeos e tem aquela imagem de que vai nascer na banheira né" [sic]. Assim como no caso de Rosa, o estudo sobre a preparação para o parto domiciliar, realizado por Feyer, Monticelli, Boehs et al. (2013) revelou que a maioria das entrevistadas e seus companheiros, idealizavam um parto na água. No entanto, dentro da banheira, a realidade do desconforto se impôs e Rosa precisou ir para outro lugar, onde pôde se sentir segura e confortável para o nascimento de seu filho. Nesse contexto, Winnicott (1945/1993) refere que a realidade externa frequentemente impõe ao indivíduo, frustrações. Contudo essa realidade também pode proporcionar alívio e satisfação.

Ressalta-se ainda, a influência da mídia diante da idealização do parto domiciliar planejado. Os meios de comunicação sempre influenciaram o comportamento das pessoas e atualmente, com a criação de novas tecnologias, têm influenciado cada vez mais. De acordo com Pereira (2018) as transformações socioeconômicas das últimas décadas desencadearam grandes mudanças nas demandas produtivas de bens e serviços. De forma paralela, a mídia através de novas tecnologias de linguagem também passou por grandes transformações, possibilitando o aumento de informações e visibilidade de fácil acesso à população. Nesse contexto, as mídias digitais e eletrônicas ganharam destaque. Assim, segundo o autor, o campo midiático tornou-se estratégico por exercer grande influência em vários processos. A mídia coloca-se na condição de mediadora, uma vez que tem o poder de atingir grande parte da sociedade, mobilizar a opinião pública e negociar as demandas com diversas e diferentes pessoas.

Nessa perspectiva, Tempesta e Carneiro (2018) afirmam que a mídia, em especial a internet, tem tido um papel importante na discussão das práticas e condutas profissionais voltadas à maternidade, visto o crescente número de relatos e vídeos de partos que são publicados nas redes sociais. As autoras referem que o compartilhamento de experiências pessoais, juntamente com informações científicas sobre a gestação, parto e puerpério têm se tornado uma ferramenta essencial para o empoderamento feminino nas questões sobre saúde reprodutiva e direitos sexuais das mulheres. 
Nesse sentido, o relato a seguir, juntamente com as anotações no diário de campo realizadas pela pesquisadora, aponta o desejo de Bromélia em registrar seu parto como uma forma de recordação e para o compartilhamento de sua experiência na mídia:

[...] tipo, já era 11:00 horas. E eu de roupa, eles tentando tirar minha calcinha, aí eu fiquei de quatro assim, de calcinha e elas (enfermeiras) querendo tirar minha calcinha e eu não querendo tirar minha calcinha porque eu achava que não. Que não era não, porque assim, eu tinha a sensação que ia começar e tava no fim, entendeu? Elas vieram querendo tirar minha calcinha e eu ficando brava porque não queria tirar a calcinha. Eu queria assim, que tirasse foto. Você vai ver depois meus vídeos, não tem partes... por quê? Pra poder mostrar sabe. Assim, então eu não queria tirar, queria ficar de calcinha. Aí eu de quatro assim, começou: "aaai" e eu senti uma água assim. Falei: "tô sentindo uma coisa, agora eu preciso tirar a calcinha, traz a banqueta”. (Bromélia)

A fala de Bromélia refere que no nascimento de sua filha, ela estava em contato com sua corporeidade, pois percebeu em tempo diferente das enfermeiras, o momento expulsivo do parto. Sua atenção também estava voltada ao desejo de registrar e expor seu parto: "eu queria assim, que tirasse foto [...] por quê? Pra poder mostrar sabe” [sic]. Dessa maneira, Bromélia demonstrou o desejo de compartilhar sua experiência de parto, o que poderia influenciar outras mulheres.

Sobre a influência da mídia no processo de parto, o estudo de Odashima, Cavaca, Oliveira, Silva e Santos Neto (2019) sobre a representação do parto, revelou que o tipo de parto a ser realizado não depende apenas do desejo inicial da mulher, uma vez que este também é influenciado pela exposição que é apresentada pela mídia. Nesse sentido, os meios de comunicação também podem desempenhar outro tipo de influência, visto que nos dias atuais são comuns nas redes sociais, imagens de partos domiciliares na banheira, com velas, flores e música. É importante esclarecer que no presente estudo, conforme os relatos de algumas participantes, as imagens de partos românticos que estão expostas nas mídias exerceram certa influência sobre a fantasia e idealização para o momento do parto. Contudo, segundo as participantes, decidir por um parto domiciliar foi uma escolha consciente, visto que houve um percurso de preparação e enfrentamento para esse processo.

Nessa perspectiva, vale ressaltar que a mídia pode exercer diferentes tipos de influência sobre o processo de gestação e parto. A mídia pode ser um canal importante de informação, discussão e mudanças sobre a saúde reprodutiva da mulher. Pode ainda, estimular 
a capacidade da mulher para fantasiar, idealizar e ritualizar o momento do parto. Mas pode também ter um papel alienante, no sentido de vender "modelos prontos" e tornar o processo de parto uma mercadoria. A esse despeito, Safra (2004) refere que a mídia oferece um espaço virtual de comunicação que apresenta uma temporalidade cada vez mais rápida e distante do tempo da corporeidade e da subjetividade. Segundo o autor, a mídia apresenta uma criatividade que seduz o ser humano com o que já está estabelecido, levando a um esquecimento de si mesmo e de suas raízes.

Ainda sobre a influência da mídia, Carvalho, Gandra, Pereira, Dias e Angelis-Pereira (2019) apontam que com a implantação de novas mídias, grande parte da população se acostumou a acessar diversos conteúdos quase que de forma instantânea. Segundo os autores, isso desencadeou um cenário onde há muita informação, mas que não necessariamente constrói conhecimento. Nesse sentido, Bondia (2002) refere que "a experiência é o que nos passa, o que nos acontece, o que nos toca" (p. 21). Contudo, o autor afirma que a sociedade está constituída pelo signo da informação onde o indivíduo, por possuir um excesso de informação encontra dificuldade para viver a experiência.

Os relatos apresentados apontam a fantasia e a idealização como mecanismos de proteção para o enfrentamento do processo do parto domiciliar planejado, principalmente no que se refere aos medos e angústias das participantes. Apontam ainda, que as mulheres podem ser influenciadas pelas imagens de partos românticos que estão sendo expostos na mídia e dessa maneira, idealizar um modelo de parto semelhante. Segundo os relatos, pode haver também, um desejo de compartilhar a experiência do parto e assim, se tornar uma agente da mídia, influenciando outras mulheres. Nesse sentido, a fala de Bromélia sugere que as mulheres que decidem compartilhar suas experiências de parto na mídia, talvez precisem ficar atentas a outros fatores além do processo de parto.

\subsubsection{Parto poder}

Essa subcategoria apresenta os principais enfrentamentos vivenciados pelas participantes durante o trabalho de parto e pós-parto, e as concepções de empoderamento provocados por essas experiências. 
Os relatos a seguir referem que enfrentar o trabalho de parto em sua dimensão fisiológica e sem anestesia, contribuiu para a sensação de poder experimentada pelas participantes:

[...] eu acho que se eu tivesse no hospital eu ia me sentir tentada às intervenções, pela facilidade de estarem disponíveis... analgesia. Eu vi depois meu expulsivo, eu fiquei pensando, se eu tivesse assistência com médicos, eu acho que eu teria tido minha episiotomia, pelo lenga lenga que foi o desprendimento dela. E eu queria saber exatamente o que que era esse tal de parto natural, do começo ao fim. Então eu fiquei assim, pensando né: "em casa eu vou ter mais, é... vai ser mais dificil eu ceder". É claro que eu poderia ceder e ir para o hospital por opção e tudo mais, mas não ter a mão, a disposição, me levaria a realmente falar: "não, tô aqui, aqui não tem nada, eu tenho que viver isso aqui tudo". E eu queria viver isso. (Orquídea)

[...] eu já meio que lembrava um pouco né (se referindo à dor dos dois partos anteriores). A gente sempre fala: "ah, mãe esquece a dor de parto, por isso que tem outro né". Tem isso mesmo, mas eu já meio que, isso não era muito preocupante pra mim, eu sabia que conseguiria lidar com a dor e que ia ter uma hora que eu ia pedir pelo amor de Deus pra me tirar dali né, como das outras vezes aconteceu. Eu falei: "oh, vocês já sabem que vai ter uma hora que eu vou pedir pra desistir, pra me levar pro hospital. Vai ter uma hora que eu vou pedir pra parar com isso". [...] engraçado que no das meninas (partos normais hospitalares), meu pensamento era de alguém fazer alguma coisa: "faz alguma coisa pra me tirar isso, faz alguma coisa". No do Érico (parto domiciliar) eu pensava: "eu tenho que fazer alguma coisa, sou eu, mеи corpo que vai funcionar, se eu não me concentrar aqui, não fizer minha parte ele também não vai conseguir fazer a dele e ele também não vai nascer”. Então inverteu as coisas. Mas a dor é muito alucinante! É muito forte né. (Gérbera)

Orquídea reconhece que se estivesse no hospital poderia ceder às intervenções, principalmente a analgesia, devido as dores do parto. Em seus estudos sobre a dor e o protagonismo da mulher na parturição, Pereira, Franco e Baldin (2011) apontam que no último trimestre de gestação, a ansiedade e o medo da dor do parto fragilizam sensivelmente a mulher e que a analgesia tem sido uma "aliada" nesse enfrentamento. As autoras referem que o medo da dor esteve presente nas 45 gestantes que foram entrevistadas e que com a proximidade do parto, esse medo transformou-se também em medo do trabalho de parto, medo do desempenho e de comprometer o bebê, medo da anestesia e medo do desconhecido. Vale lembrar que uma das especificidades do parto domiciliar planejado é enfrentar a dor sem analgesia, uma vez que esta só pode ser ministrada no hospital. Dessa maneira, a escolha pelo parto domiciliar impõe à mulher as expectativas de lidar com essa dor.

Sobre o medo da dor, Gérbera relata que nos partos anteriores estava no hospital onde contava com recursos externos e intervenções hospitalares e nessa condição não se 
percebia como protagonista do parto: "no das meninas (partos normais hospitalares), meu pensamento era de alguém fazer alguma coisa: 'faz alguma coisa pra me tirar isso, faz alguma coisa", [sic]. Por outro lado, no parto domiciliar, ela se sentia responsável pelo enfrentamento do medo da dor e o processo do parto: "eu pensava: 'eu tenho que fazer alguma coisa, sou eu, mеи corpo que vai funcionar, se eu não me concentrar aqui, não fizer minha parte ele também não vai conseguir fazer a dele e ele também não vai nascer"” [sic]. Segundo Santos (2018) a dor do parto tem significados diferentes conforme o contexto social, que podem estar associados a fatores culturais e emocionais como crenças, valores, religião, medos, ansiedade e insegurança. A autora aponta que o medo é um fator significativo e recorrente relacionado ao parto e pode interferir na avaliação da dor pela parturiente. Nesse sentido, o relato de Gérbera sugere que no parto em casa, mesmo estando amparada por seu companheiro e uma equipe especializada, o processo da dor foi uma experiência intrínseca. Sugere ainda, assim como no relato de Orquídea, que no parto há um medo não só da dor, mas do que é desconhecido e imprevisível.

De acordo com Pereira et al. (2011), o medo da dor pode influenciar no desempenho e protagonismo da mulher no parto, interferindo no processo de maternagem. Segundo as autoras, para algumas mulheres, passar pela dor do parto sem analgesia pode legitimar a "competência de ser mãe" e também associar a ideia de "heroísmo" ao amadurecimento da mulher. Nessa perspectiva, enfrentar os desafios do parto domiciliar planejado, que inclui passar pela dor sem analgesia, parece ter empoderado as participantes para a maternagem e questões que extrapolam o parto.

Segundo Santos (2018), a maneira como a mulher compreende o processo do parto e nascimento pode influenciar na sua escolha pelo tipo de parto. A autora aponta a necessidade de compreensão sobre o medo das gestantes em relação à dor do parto, uma vez que esse medo pode levar a uma cesárea eletiva. A autora acrescenta que estudar sobre o medo da dor no parto e compreender como as mulheres a vivenciam, pode trazer mudanças significativas na assistência pré-natal, proporcionando maior conhecimento e segurança à gestante. Dessa maneira, é importante que haja um resgate e uma ressignificação do parto para que a mulher possa se sentir protagonista. Nessa perspectiva, Oliveira (2014) ressalta que em nossa sociedade, a gestante parece ter pouco domínio sobre a fisiologia e os indicadores favoráveis ou contrários de cada via de parto, o que dificulta que a mulher possa ser protagonista do nascimento de seu filho. A autora refere que no momento do parto, a autonomia da mulher está diretamente relacionada ao conhecimento que ela tem sobre o tipo de parto que está 
vivenciando. Nesse contex to e como descrito anteriormente (vide 4.2.2), todas as participantes da presente pesquisa estudaram e se prepararam para o parto domiciliar, o que indica que ter acesso à informação é um dos elementos que pode ajudar a mulher a permanecer na escolha pelo parto domiciliar.

Gutman (2013) aponta que a dor tem um papel importante no parto, pois permite que a mulher se desligue do "mundo pensante" para se conectar com o trabalho de parto e o nascimento de seu filho. Contudo, a autora considera que dor é diferente de sofrimento, uma vez que a dor faz parte do processo físiológico do parto e o sofrimento está relacionado ao fato da mulher se sentir só, desprotegida, desamparada e em muitos casos, humilhada e desrespeitada pelas pessoas que a acompanham nesse processo. Nesse sentido, compreende-se que a dor faz parte do processo fisiológico do parto e prepara a mulher para o nascimento do seu filho. Entretanto, segundo os relatos apresentados, os medos que antecedem o parto, como o medo da dor, podem gerar sofrimento e dúvidas sobre a capacidade da mulher para suportar tanto a dor fisiológica quanto a emocional.

Para a maioria das entrevistadas, lidar com o medo da dor foi um dos maiores desafios do parto domiciliar planejado. Contudo, de acordo com Santos (2018), um ambiente acolhedor e com suporte adequado de uma equipe especializada pode minimizar o medo e a experiência da dor. Nessa perspectiva, Gutman (2013) esclarece que quando a mulher se sente acolhida, protegida e respeitada pelas pessoas que estão ao seu redor, mesmo que o trabalho de parto seja doloroso e cansativo, ela pode se sentir fortalecida para enfrentar essa experiência.

Segundo os relatos a seguir, vivenciar o parto domiciliar planejado revelou-se como uma experiência transformadora que reverberou também no pós-parto:

[...] me preparei pra caramba, vivenciei o parto corporal mesmo sabe, uma coisa de entrega do corpo assim, um processo fisiológico, de você sentir. E uma coisa, é um sentimento de poder, você ter esse parto natural sem anestesia, sem nada, é você sozinha assim, você se sente tão poderosa que eu acho que isso impacta, tese pro seu futuro: os impactos, em pósparto. Pergunta pra turma de PD (parto domiciliar) se teve "baby blues", depressão, o quanto foi difícil. Foi difícil? É, você fica sem dormir, dá uma tristezazinha de vez em quando, fase de cólica. Mas eu acho que isso, não sei, fica aí pra você pensar. Porque gente, eu não sei o que é essa tristeza que todo mundo sente ou se é tão difícil, porque parece que você dá conta ali, o ser saiu de dentro de você, você pegou, você fez aquilo que precisava e você sustenta ele. (Bromélia) 
Existe riscos de ter em casa? Existe também, mas têm todos os benefícios não médicos né, como você está vendo né, acho que você está tendo contato com isso, de que para tomar uma decisão, talvez não seja relevante, mas para a própria mulher que vai parir é muito importante né, para a família como um todo né. E isso vai influenciar talvez a maternidade né, pós-maternidade, depois assim. Não a via de parto, mas assim, o fato dela poder tomar decisão do que ela acha que é melhor pra ela né, não o médico só dizendo né, mas a opinião dela também tem importância, que é o que a gente fala que é o protagonismo né. (Hortência)

[...] então, foi bem especial assim, bem diferente de tudo o que eu tinha pensado, então para mim foi, gente foi mágico, tipo, como assim, eu não ia passar desta vida sem ter uma experiência desta sabe. E eu acho que depois deste parto eu mudei muito assim, tipo: "cara como eu sou foda né", olha só, porque eu, às vezes era meio insegura, não sei o que. De uma coisa que eu tive muito orgulho na minha vida, foi do meu parto assim, sabe. (Amarílis)

Bromélia aponta que vivenciar o processo fisiológico do parto, de forma natural e sem anestesia, lhe trouxe "um sentimento de poder" [sic]. Segundo ela, viver toda essa experiência, onde "o ser saiu de dentro de você, você pegou" [sic], lhe conferiu o poder de "sustentar" o outro. O fato de ter vivido o processo do parto domiciliar planejado, com todos os seus enfrentamentos, parece ter despertado em Bromélia o "poder" de sustentar seu filho, que vai além da amamentação. Nesse contexto, Winnicott (1964/2016), na palestra "Este feminismo" ministrada em 1964, discorre sobre a importância e o empoderamento da mulher, uma vez que, todo homem e toda mulher "vieram de uma mulher", pois todos cresceram dentro de um útero e nasceram de uma mulher. $\mathrm{O}$ autor aponta que a questão não é apenas ter estado dentro de uma mulher e ter nascido dela e sim, ter sido completamente dependente de uma mulher.

De acordo com Winnicott (1964/2016, 1960/2008), o ser humano nasce com uma tendência hereditária para a maturação, mas precisa de um ambiente facilitador satisfatório para que possa se desenvolver. E de maneira geral, inicialmente quem proporciona esse ambiente é a mulher, a mãe. Assim, segundo o autor, no início da vida, a saúde mental do ser humano guarda um vínculo estreito com uma mulher. Contudo, vale ressaltar, que o sentimento de poder vivenciado pelas participantes, lhes foi legitimado não apenas por ter gerado e parido seus filhos, mas também pelos desafios enfrentados no processo do parto domiciliar planejado.

Segundo Bromélia, a experiência de ter seu filho em casa ressignificou seu pós-parto. Para Hortência é o protagonismo da mulher diante do processo do parto domiciliar planejado e não só a via de parto que pode influenciar no pós-parto e abrir novas possibilidades de 
maternagem. Nesse sentido, Amarílis relata que viver a experiência de ter um filho em casa, provocou transformações para além da maternidade, uma vez que ela afirma: "depois deste parto eu mudei muito assim" [sic]. Dessa forma, percebe-se que as vivências no pós-parto descritas pelas participantes, estão relacionadas não apenas ao fato de terem passado por um parto normal, que em geral, tem uma recuperação fisiológica mais rápida do que uma cesariana e dessa maneira, permite que a mulher esteja mais disponível para cuidar do seu bebê. De acordo com os relatos, o que realmente parece ter impactado positivamente no pósparto das participantes, foi o percurso de enfrentamento, superação e empoderamento em todo o processo do parto domiciliar.

Assim como outras participantes, vivenciar um parto em casa trouxe à Tulipa um sentido de empoderamento elaborado por ela, depois do parto:

[...] vitória, mais do que uma sensação de, eu sabia que ela ia nascer bem, sabe essas encanações: "ai porque o bebê", tipo: "não, meu bebê vai nascer bem", eu tinha esta convicção, era assim, eu consigo sabe, eu consigo, eu consegui, eu consegui sabe e acabou. [...] então foram três horas de trabalho de parto ativo né, ela nasceu super bem, ótima, eu estava bem, porque depois do expulsivo acabou né e eu tava me sentindo uma vitoriosa assim né. Eu estava na minha casa, na minha cama, ninguém ia me acordar no meio da noite com uma luz na minha cara, com um pediatra para auscultar uma criança que está dormindo. E de lá eu fui para a minha cama, a placenta demorou um pouquinho, mas também depois saiu. É isso, eu estava em casa, foi um processo que foi fisiológico, eu me sentia muito, eu acho que a sensação de poder veio depois né, de me sentir poderosa, de falar: "não, eu consigo", essa coisa da vitória, de falar: "é possivel sabe, é fisiológico mesmo, será que é fisiológico mesmo"? [...] hoje eu acho que isso, não só em relação ao parto né, são várias questões da vida, desta vida moderna que a gente tem que se apropriar de tudo para dar conta de tanta demanda né. Mas o parto é um momento, eu acho que ele é muito... delicado, ele é muito crucial para depois como as coisas vão se desenrolar né e uma gestante, ela tem que se empoderar até o último fio de cabelo. (Tulipa)

Tulipa que já havia passado por uma cesárea e um parto normal hospitalar com diversas intervenções, afirma que vivenciar o processo do parto domiciliar foi uma "vitória" [sic]. A participante, refere a importância de estar em um ambiente familiar no momento do nascimento de sua terceira filha, para que se sentisse protagonista do processo e seu parto ocorresse de forma mais natural e sem intervenções desnecessárias: "eu estava na minha casa, na minha cama, ninguém ia me acordar no meio da noite” [sic]. Odent (2002) aponta que um ambiente familiar, sereno e sem muitas distrações externas, pode facilitar para que a mulher esteja em contato consigo mesma e o trabalho de parto siga de forma mais natural. Tulipa acrescenta que "depois do expulsivo acabou” [sic], pois estava em sua casa, com uma 
equipe especializada e não precisaria passar por intervenções hospitalares contra sua vontade, como nos partos anteriores. Nesse sentido, Oliveira (2014) esclarece que a capacidade de ser protagonista está relacionada às condições de escolhas e ações do indivíduo, mas que podem ser limitadas devido ao contexto social em que estejam inseridos.

Os relatos das participantes apontam que o processo de ter um filho em casa favoreceu uma maior confiança em relação à maternagem e em si mesmas. Sobre a confiança materna, Arante (2017) refere que corresponde aos sentimentos subjetivos que a mulher desenvolve sobre as responsabilidades de ser mãe. É um processo que conduz à experiência de competência no desempenho da função materna e integra a capacidade de assumir os cuidados com o filho. A autora acrescenta que a confiança materna é um dos fatores que promove o vínculo mãe-bebê e que resulta da rede de apoio oferecida à mãe, satisfação conjugal, saúde física e mental da mulher, juntamente com as características do bebê. Sendo que a interação desses fatores contribui para o desenvolvimento do bebê.

Os relatos sugerem ainda, que a confiança materna foi significativa no pós-parto, indicando que a experiência do parto domiciliar planejado pode trazer impactos positivos para além do momento do parto, como relata Tulipa: "hoje eu acho que isso, não só em relação ao parto né, são várias questões da vida, desta vida moderna que a gente tem que se apropriar de tudo para dar conta de tanta demanda né” [sic]. Nesse sentido, Faria (2016) aponta que o pós-parto é um período de grandes mudanças hormonais e biológicas, que exige da mulher o desenvolvimento de novas competências maternas para a adaptação familiar e que a confiança materna pode contribuir para esse desenvolvimento.

A fala de Tulipa traz alguns aspectos que valem ser ressaltados. De um lado, o parto domiciliar planejado se mostra como um processo natural e fisiológico, de outro, a participante afirma que a mulher "tem que se empoderar até o último fio de cabelo" [sic]. Nesse contexto, o presente estudo revelou que vivenciar o processo do parto domiciliar planejado com suas especificidades, como o de enfrentamento dos próprios medos, fantasias, angústias, dor, posicionamento com a família e a sociedade e o questionamento sobre o sistema hospitalar, conferiu e legitimou às participantes, um sentimento de poder que foi além do momento do parto. 
CONSIDERAÇÕES FINAIS 


\section{CONSIDERACÕES FINAIS}

Como já foi dito, atualmente tem aumentado o número de mulheres que estão se informando e optando pelo parto domiciliar planejado, sobretudo nos centros urbanos. É crescente também o compartilhamento de relatos e imagens de partos na mídia e redes sociais, por mulheres que passaram por essa experiência, assim como por profissionais envolvidos nesse tipo de parto. Em contrapartida, foi possível verificar no presente trabalho, que os estudos científicos nessa área ainda são escassos, principalmente aqueles que privilegiam a perspectiva das mulheres.

Considerando a crescente organização e influência dos Movimentos Sociais que defendem a ideia do parto domiciliar planejado, mobilizando, informando e oferecendo apoio às mulheres que buscam uma alternativa ao parto hospitalar, colidindo com a hegemonia do modelo biomédico; cumpre esclarecer que esse estudo foi pautado pela isenção de comprometimento ou defesa dessas perspectivas. Dessa forma, a pesquisa foi delineada com o objetivo de compreender a experiência de mulheres que optaram pelo parto domiciliar planejado.

Ressalta-se, inicialmente, que em relação à caracterização das participantes, todas possuíam curso superior completo, algumas com pós-graduação e renda familiar média de 12 salários mínimos; o que sugere que o acesso ao parto domiciliar planejado ainda é restrito, uma vez que sofre influência de fatores socioculturais e econômicos.

Embora a análise e discussão dos resultados apresentem sínteses em Categorias Temáticas, a singularidade das experiências, a partir da subjetivação das participantes, foi fundamental para a compreensão de elementos presentes nesse processo.

Sobre a escolha pelo parto domiciliar planejado, as principais motivações das participantes foram a insatisfação com atendimento hospitalar, o uso de intervenções consideradas por elas como desnecessárias e desrespeitosas e o desejo de vivenciar um parto mais natural. A maior parte das entrevistadas já havia passado por experiências hospitalares, como partos e procedimentos decorrentes de abortos. Contudo, as motivações pela escolha do parto domiciliar foram semelhantes mesmo para as participantes que não haviam vivido essas experiências. Outras motivações também foram apontadas, como o conforto e familiaridade de suas casas para vivenciar o parto e pós-parto, o que lhes permitiu se alimentarem e movimentarem quando e da forma que desejassem, além da possibilidade de estarem em contato com seus bebês, logo após o nascimento e posteriormente. Essas questões se 
mostraram relevantes para as entrevistadas e são condições oferecidas pelo parto domiciliar planejado.

Além da motivação para o parto domiciliar planejado, a decisão sobre o compartilhamento da escolha por esse tipo de parto com a família, revelou formas de como as famílias foram integradas nesse processo. Parte das entrevistadas não compartilhou sua decisão sobre o parto domiciliar, algumas elegeram determinados familiares para contar e outras compartilharam com todos. Entre outros aspectos, a decisão por não contar aos familiares, especialmente para a mãe, pareceu fragilizar as participantes. Contudo, também pode ter sido uma forma de proteção aos vínculos familiares.

Durante a gestação e o parto, a mulher necessita dispor de uma rede de apoio familiar e social e não compartilhar a decisão pelo parto domiciliar pode restringir esse apoio. Nesse contexto, o "segredo" pode constituir uma forma de sofrimento para a gestante e compartilhar com a família poderia ajuda-la a lidar com seus medos e angústias diante dos enfrentamentos do processo do parto e fortalecer as relações familiares. Mas para tanto, a equipe precisa estar atenta a tal questão e as significações que carrega para cada gestante, de modo a acolher e facilitar a mediação e diálogo com a família.

A partir da análise das entrevistas, foi possível identificar a multiplicidade de sentidos que podem ser atribuídos ao parto domiciliar planejado. Partindo do pressuposto de que tanto no parto hospitalar quanto no domiciliar, as mulheres podem vivenciar diversas condições de vulnerabilidade, a análise dos relatos indicou algumas contradições que emergem na experiência do parto domiciliar planejado.

Uma das questões diz respeito às expectativas das participantes em poder realizar uma experiência de parto, na qual elas ocupem a centralidade nas decisões. Comumente, nos partos realizados no hospital, o protagonismo é assumido pela equipe, que delibera sobre os procedimentos e cuidados com a parturiente e o recém-nascido. Por outro lado, as condições oferecidas pelo parto domiciliar planejado ampliam o protagonismo da mulher, pois em casa, ela tem maior liberdade de escolhas diante do parto e pós-parto.

Nesse contexto, emerge a condição paradoxal, pois quanto mais aumenta a liberdade de escolhas, mais a mulher fica atrelada às responsabilidades que seriam da competência hospitalar, se estivesse nesse ambiente. Assim, o parto domiciliar planejado exige uma série de condições e providências, que podem pressionar a gestante e favorecer em algumas, a emergência de necessidade de controlar as situações e até mesmo a circulação de afetos, como uma forma de minimizar medos e angústias. 
Fantasiar e idealizar o processo do parto domiciliar planejado foi outra forma encontrada pelas participantes para lidar com os enfrentamentos desse processo. Lembrando que a mídia e redes sociais têm apresentado cada vez mais relatos e imagens de partos domiciliares, estimulando a imaginação e consumo de rituais idealizados. Nesse contexto, as mulheres podem ser capturadas e atravessadas por discursos de "partos românticos" realizados na banheira, com velas, flores e outros elementos imagéticos que podem potencializar a idealização, a partir de modelos prontos.

O estudo apontou que, por um lado, esses elementos e rituais contribuíram para que algumas participantes pudessem fantasiar o parto e assim, minimizar seus medos e angústias. Por outro, podem ter gerado sofrimento, uma vez que as entrevistadas tiveram que lidar com os imprevistos do parto e algumas não conseguiram concretizar suas fantasias. Dessa maneira, tais elementos devem ser pensados a partir da singularidade de cada mulher e uma equipe acolhedora e sensível a essas questões pode ajudar com os imprevistos desse percurso.

Vivenciar o processo do parto domiciliar planejado com todos seus enfrentamentos, desde a escolha até o pós-parto, pareceu provocar transformações em relação ao empoderamento feminino das participantes. Para a maioria das entrevistadas lidar com o medo da dor sem analgesia, condição específica do parto domiciliar planejado, foi um dos maiores desafios. O percurso de enfrentamento das participantes frente às próprias angústias, medos e julgamentos dos familiares, também reverberou em empoderamento no pós-parto. Nesse contexto, o processo do parto domiciliar planejado promoveu novas relações da mulher consigo mesma, com o companheiro e com seus familiares.

O estudo se limitou a entrevistar mulheres que passaram pela experiência do parto domiciliar planejado, uma vez que era necessário um recorte metodológico, dadas as limitações de tempo do mestrado, o que possibilitou um maior aprofundamento de suas perspectivas. Contudo, o presente trabalho abre possibilidades para novos estudos que podem contribuir nessa área, incluindo a compreensão das experiências de outras pessoas envolvidas no processo do parto domiciliar planejado, como os companheiros e familiares. Outra possibilidade seria um estudo longitudinal que acompanhasse a mulher desde a gestação até o pós-parto, para maior aprofundamento do percurso do parto domiciliar planejado. Tendo em vista a complexidade de especificidades tanto do parto domiciliar, quanto do hospitalar, outro recorte de pesquisa seria a compreensão da experiência de mulheres que se prepararam para o parto domiciliar, iniciaram o trabalho de parto em casa, mas foram transferidas para o hospital, em decorrência de intercorrências ou por vontade própria. 
Por meio do desenvolvimento da pesquisa, foi possível compreender a singularidade da experiência de mulheres que realizaram partos domiciliares planejados e identificar múltiplos sentidos que se apresentaram nesse processo. O estudo traz possibilidades de reflexões que podem contribuir para a comunidade científica e para a sociedade, assim como para a Psicologia, pois expande a perspectiva fisiológica do parto, apontando algumas implicações para a saúde mental das parturientes. Os resultados ampliam o olhar sobre o processo do parto domiciliar planejado, uma vez que revelam dificuldades vivenciadas pelas participantes, permeadas por medos, angústias e sofrimentos, mas também pela descoberta de recursos psicossociais para o enfrentamento de questões relacionados a maternidade, vínculos familiares e a feminilidade. Assim, compreende-se que no processo do parto domiciliar planejado, a singularidade de cada mulher deve ser respeitada para que não haja o risco de reproduzir um cuidado "protocolar", impondo modelos ou condições consideradas ideais para esse processo.

Nesse contexto, embora o estudo tenha privilegiado as experiências do parto domiciliar planejado, as contribuições podem se estender para os processos de parto na rede hospitalar, uma vez que a melhor compreensão sobre alguns enfrentamentos das parturientes podem contribuir para a assistência de humanização ao parto e nascimento, envolvendo os profissionais da área, inclusive psicólogos. 


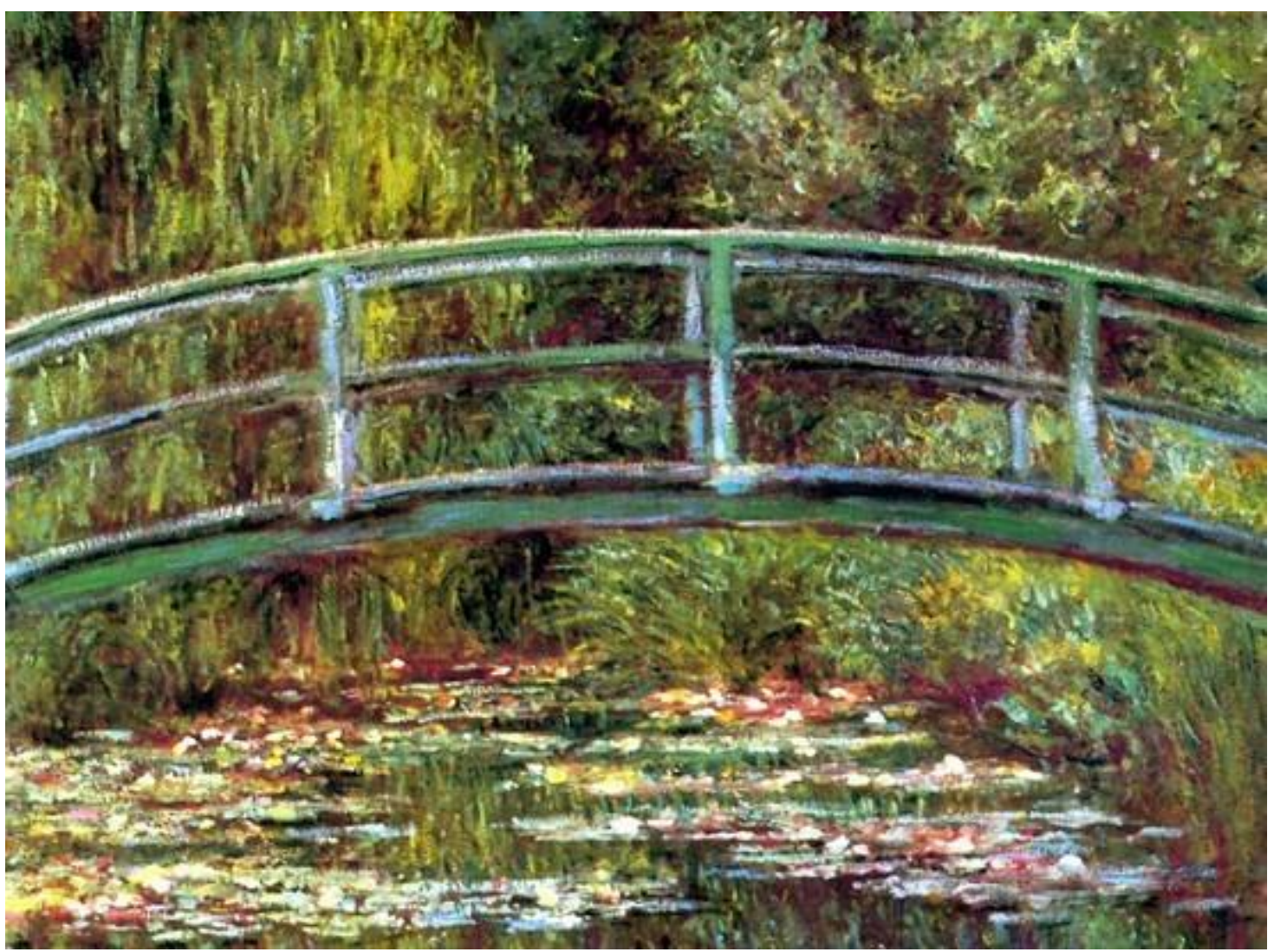

Ponte Japonesa (Claude Monet,1889)

"Quem elegeu a busca, não pode recusar a travessia"

Guimarães Rosa 
REFERÊNCIAS 


\section{$\underline{\text { REFERENCIAS }^{2}}$}

Agência Nacional de Saúde Suplementar. (2015). Projeto Parto Adequado. Rio de Janeiro, RJ: Agência Nacional de Saúde Suplementar.

Aquino, E. M. L. (2014). Para reinventar o parto e o nascimento no Brasil: de volta ao futuro. Cadernos de Saúde Pública,30(Supl. 1), S8-S10, doi:10.1590/0102311XPE01S114

Arante, F. O. (2017). Associação entre depressão puerperal e confiança materna em mulheres com histórico de depressão na gravidez. (Dissertação de Mestrado). Recuperado de https://www.teses.usp.br/teses/disponiveis/5/5137/tde-25102017095819/pt-br.php

Araújo, C. A. S. (2005). O ambiente em Winnicott. Winnicott E-Prints, 4(1), 21-34.

Balaskas, J. (2003). Parto Ativo: guia prático para o parto natural. São Paulo, SP: Ground.

Barbosa, C. M. (2013). Women and traditional midwives: care practices during the processo $\mathrm{f}$ labor and birth at home. Revista de Pesquisa: Cuidado é Fundamental Online, [S.1.]. v.5. n.1,p.3206-3220, doi:10.9789/2175-5361.2013.v5il.3206-3220

Bardin, L. (2011). Análise de Conteúdo. São Paulo, SP: Edições 70.

Barros, José Augusto C.. (2002). Pensando o processo saúde doença: a que responde o modelo biomédico? Saúde e Sociedade, 11(1), 67-84, doi:10.1590/S010412902002000100008

Bondía, J. L. (2002). Notas sobre a experiência e o saber de experiência. Revista Brasileira de Educação, (19), 20-28, doi:10.1590/S1413-24782002000100003

Busanello, J., Kerber, N. P. C., Mendoza-Sassi, R. A., Mano, P. S., Susin, L. R. O., \& Gonçalves, B. G. (2011). Atenção humanizada ao parto de adolescentes: análise das práticas desenvolvidas em um centro obstétrico. Revista Brasileira de Enfermagem, 64(5), 824-832, doi:10.1590/S0034-71672011000500004

Carneiro, R. (2013). Daquilo que os médicos quase não falam: transe e êxtase na cena de parto. Experiências e percepções dissidentes de saúde e de bem-estar na contemporaneidade. Ciência \& Saúde Coletiva, 18(8), 2369-2378, doi:10.1590/S141381232013000800021

Carvalho, G. R., Gandra, F. P. P., Pereira, R. C., Dias, L. B., \& Angelis-Pereira, M. C. (2019). Percepção sobre mídia e comportamento na compra de alimentos: estudo com consumidores de dois municípios do sul de Minas Gerais. Brazilian Journal of Food Technology, 22, e2018170, doi:10.1590/1981-6723.17018

\footnotetext{
${ }^{2}$ De acordo com o estilo APA - American Psychological Association
} 
Castro, C. M. (2015). Os sentidos do parto domiciliar planejado para mulheres do município de São Paulo, São Paulo.Cadernos Saúde Coletiva,23(1), 69-75, doi:10.1590/1414462X201500010012

Castro, C. M., Azevedo, A. F. P. (2018). Narrativas sobre parto domiciliar planejado após parto hospitalar. Revista Família, Ciclos de Vida e saúde no Contexto Social. revistaeletronica/index.php/refacs/article/view/2794, doi:10.18554/refacs.v6i1.2794

Cavalcanti, M. L. V. C. (2018). O ritual e a brincadeira: rivalidade e afeição no bumbá de Parintins, amazonas. Mana, 24(1),9-38, doi:10.1590/1678-49442018v24n1p009

Cavaler, C. M., Castro, A, Figueiredo, R. C., Araújo, T. N. (2018). Representações no parto para mulheres que foram parturientes. Id on Line, Revista Multidisciplinar $e$ de Psicologia, doi:10.14295/idonline.v12i41.1158

Cecatti, J. G. (2014). Crenças e crendices sobre as atuais intervenções durante o trabalho de parto e parto no Brasil.Cadernos de Saúde Pública,30(Supl. 1), S33-S35, doi:10.1590/0102-311XCO01S114

Chauvet, E. (Diretor). (2013). O Renascimento do Parto. [Filme-vídeo]. São Paulo, SP: Chauvet Filmes.

Chauvet, E. (Diretor). (2015). O Renascimento do Parto 2. [Filme-vídeo]. São Paulo, SP: Chauvet Filmes.

Chauvet, E. (Diretor). (2018). O Renascimento do Parto 3. [Filme-vídeo]. São Paulo, SP: Chauvet Filmes.

Chaves, R. L. (2014). O nascimento como experiência radical de mudança. Cadernos de Saúde Pública, 30(Supl. 1), S14-S16, doi:10.1590/0102-311XPE03S114

Collaço, V. S., Santos, E. K. A., Souza, K. V., Alves, H. V., Zampieri, M. F., \& Gregório, Vitória Regina Petters. (2017). The meaning assigned by couples to planned home birth supported by nurse midwives of the hanami team. Texto \& Contexto Enfermagem, 26(2), e6030015, doi:10.1590/0104-07072017006030015

Costa, R., Pacheco, A., \& Figueiredo, B. (2012). Antecipação e experiência emocional do parto. Psicologia, Saúde \& Doenças, 13(1), 15-35. Recuperado de http://S1645$00862012000100003 \& \operatorname{lng}=\mathrm{pt} \& \operatorname{tng}=\mathrm{pt}$

Dezan, S. Z. (2015). Família monoparental feminina: a experiência materna e o desenvolvimento do self infantil. (Dissertação de Mestrado). Recuperado de https://repositorio.usp.br/item/002720203

Diniz, C. S. G., d'Orsi, E., Domingues, R. M. S. M., Torres, J. A., Dias, M. A. B., Schneck, C. A., Lansky, S., Teixeira, N. Z. F., Rance, S., \& Sandall, J. (2014). Implementação da presença de acompanhantes durante a internação para o parto: dados da pesquisa nacional Nascer no Brasil.Cadernos de Saúde Pública, 30(Supl. 1), S140-S153, doi:10.1590/0102$311 \mathrm{X} 00127013$ 
Diniz, S. G. (2014). O renascimento do parto, e o que o SUS tem a ver com isso. Interface Comunicação, Saúde, Educação, 18(48), 217-220, doi:10.1590/1807-57622013.0910

Domingues, R. M. S. M., Dias, M. A. B., Nakamura-Pereira, M., Torres, J. A., d'Orsi, E., Pereira, A. P. E., Schilithz, A. O. C., \& Leal, M. C. (2014). Processo de decisão pelo tipo de parto no Brasil: da preferência inicial das mulheres à via de parto final. Cadernos de Saúde Pública, 30(Supl. 1), S101-S116, doi:10.1590/0102-311X00105113

d'Orsi, E., Brüggemann, O. M., Diniz, C. S. G., Aguiar, J. M., Gusman, C. R., Torres, J. A., Angulo-Tuesta, A., Rattner, D., \& Domingues, R. M. S. M. (2014). Desigualdades sociais e satisfação das mulheres com o atendimento ao parto no Brasil: estudo nacional de base hospitalar.Cadernos de Saúde Pública,30(Supl. 1), S154-S168, doi:10.1590/0102$311 \mathrm{X} 00087813$

Downe, S. (2014). Reduzindo intervenções de rotina durante o trabalho de parto e parto: primeiro, não causar dano. Cadernos de Saúde Pública,30(Supl. 1), S37S39, doi:10.1590/0102-311XCO04S114

Faria, N. A. S. (2016). A preparação para o nascimento no desenvolvimento da confiança materna nos cuidados ao recém nascido. (Dissertação de Mestrado). Recuperado de https://comum.rcaap.pt/handle/10400.26/17512

Ferigato, S. H., Silva, C. R., \& Ambrosio, L. (2018). Corporality of pregnant women and occupational therapy: possible actions in the Primary Health Care. Cadernos Brasileiros de Terapia Ocupacional, 26(4), 768-783, doi:10.4322/2526-8910.ctoao1173

Feyer, I. S. S., Monticelli, M., Boehs, A. E., \& Santos, E. K. A. (2013). Rituais de cuidado realizados pelas famílias na preparação para a vivência do parto domiciliar planejado. Revista Brasileira de Enfermagem,66(6), 879-886, doi:10.1590/S003471672013000600011

Feyer, I. S. S., Monticelli, M., \& Knobel, R. (2013). Perfil de casais que optam pelo parto domiciliar assistido por enfermeiras obstétricas. Escola Anna Nery, 17(2), 298-305, doi:10.1590/S1414-81452013000200014

Frank, T. C., \& Pelloso, S. M. (2013). A percepção dos profissionais sobre a assistência ao parto domiciliar planejado. Revista Gaúcha de Enfermagem, 34(1), 2229, doi:10.1590/S1983-14472013000100003

Gama, S. G. N., Viellas, E. F., Schilithz, A. O. C., Theme Filha, M. M., Carvalho, M. L., Gomes, K. R. O., Costa, M. C. O., \& Leal, M. C. (2014). Fatores associados à cesariana entre primíparas adolescentes no Brasil, 2011-2012. Cadernos de Saúde Pública, 30(Supl. 1), S117-S127, doi:10.1590/0102-311X00145513

Gomes, M. A. S. M. (2014). Compromisso com a mudança. Cadernos de Saúde Pública, 30(Supl. 1), S41-S42, doi:10.1590/0102-311XCO06S114

González-Rey, F. (2002). Pesquisa Qualitativa em Psicologia: Caminhos e desafios. São Paulo, SP: Pioneira Thomson Learning. 
Gutfriend, C. (2010). Narrar, ser mãe, ser pai \& outros ensaios sobre a parentalidade. Rio de Janeiro, RJ: Difel.

Gutman, L. (2013). A Maternidade e o encontro com a própria sombra. Rio de Janeiro, RJ: Best Seller.

Hidalgo-Lopezosa, P., Hidalgo-Maestre, M., \& Rodríguez-Borrego, M. A. (2016). Labor stimulation with oxytocin: effects on obstetrical and neonatal outcomes. Revista LatinoAmericana de Enfermagem, 24, e2744, doi:10.1590/1518-8345.0765.2744

Hiene, R. R. S. (2018). Experiências de casais com parto domiciliar: da escolha à vivência. (Dissertação de Mestrado). Recuperado de https://repositorio.ufscar.br/handle/ufscar/10051

Koettker, J. G., Brüggemann, O. M., \& Dufloth, R. M. (2013). Partos domiciliares planejados assistidos por enfermeiras obstétricas: transferências maternas e neonatais. Revista da Escola de Enfermagem da USP, 47(1), 15-21, doi:10.1590/S0080-62342013000100002

Koettker, J. G., Bruggemann, O. M., Freita, P. F., Riesco, M. L. G., \& Costa, R. (2018). Obstetric practices in planned home births assisted in Brazil. Revista da Escola de Enfermagem da USP, 52, e03371, doi:10.1590/s1980-220x2017034003371

Lansky, S., Friche, A. A. L., Silva, A. A. M., Campos, D., Bittencourt, S. D. A., Carvalho, M. L., Frias, P. G., Cavalcante, R. S., \& Cunha, A. J. L. A. (2014). Pesquisa Nascer no Brasil: perfil da mortalidade neonatal e avaliação da assistência à gestante e ao recémnascido. Cadernos de Saúde Pública,30(Supl. 1), S192-S207, doi:10.1590/0102$311 X 00133213$

Leal, M. C., \& Gama, S. G. N. (2014). Nascer no Brasil. Cadernos de Saúde Pública, 30(Supl. 1), S5, doi:10.1590/0102-311XED01S114

Leal, M. C., Pereira, A. P. E., Domingues, R. M. S. M., Theme Filha, M. M., Dias, M. A. B., Nakamura-Pereira, M., Bastos, M. H., \& Gama, S. G. N. (2014a). Intervenções obstétricas durante o trabalho de parto e parto em mulheres brasileiras de risco habitual. Cadernos de Saúde Pública,30(Supl. 1), S17-S32, doi:10.1590/0102$311 \mathrm{X} 00151513$

Leal, M. C., Pereira, A. P. E., Domingues, R. M. S. M., Filha, M. M. T., Dias, M. A. B., Nakamura-Pereira, M., Bastos, M. H., \& Gama, S. G. N. (2014b). Ampliando o debate. Cadernos de Saúde Pública,30(Supl. 1), S43-S47, doi:10.1590/0102311XCO07S114

Lei $\mathrm{n}^{\circ} .11 .108$, de 07 de abril de 2005. (2005). Garante as parturientes o direito á presença de acompanhante durante o trabalho de parto, parto e pós-parto imediato no âmbito do Sistema único de Saúde - SUS. Diário Oficial da União, seção 1.

Lei $\mathrm{n}^{\circ} 15.759$, de 25 de março de 2015. (2015) Assegura o direito ao parto humanizado nos estabelecimentos públicos do Estado e dá outras providências. São Paulo-SP. Diário Oficial da União, seção 1. 
Lessa, H. F., Tyrrell, M. A. R., Alves, V. H., \& Rodrigues, D. P. (2014). Information for the option of planned home birth: women's right to choose. Texto \& Contexto Enfermagem, 23(3), 665-672. https://dx.doi.org/10.1590/0104-07072014000930013

Lobo, S. (2008). As condições de surgimento da "Mãe Suficientemente Boa". Revista Brasileira de Psicanálise, 42(4), 67-74. Recuperado de http://pepsic.bvsalud.org/scielo.php?script=sci_arttext\&pid=S0486641X2008000400009\&lng=pt\&tlng=pt

Lovo, L. M. A. (2009). O trabalho de parto como fenômeno psicossomático. (Dissertação de Mestrado). Recuperado de https://tede2.pucsp.br/handle/handle/15826

Martinez-Molla, T. M., Solano R., C.; Siles G. J. (2013). Yo acompaño: experiencia del padre en la decisión del parto en casa. Index Enfermería Granada, v. 22, n. 1-2, doi:10.4321/S1132-12962013000100019

Martins, C.A.; Almeida, N.A.M. \& Mattos, D.V. (2012). Parto domiciliario planeado: asistido por enfermero obstetra. Enfermería global, 11 (27), 306-311.

Mattos, D. V. (2018). As relações com a parturiente na assistência ao Parto domiciliar: Perspectivas tradicionais e modernas. (Tese de Doutorado). Recuperado de http://bdtd.ibict.br/vufind/Record/PUC_GO_f421e58bbb5045bb499b596681e58d4b

Mijolla-Mellor, S. (2005). Idealização. In Dicionário Internacional de Psicanálise. Rio de Janeiro, RJ: Imago.

Minayo, M.C. (2009). Pesquisa Social: técnica, método e criatividade. Petrópolis, RJ: Vozes.

Minayo, M. C. S. (2012). Análise qualitativa: teoria, passos e fidedignidade. Ciência e Saúde Coletiva 17(3), 621-626, doi: 10.1590/S1413-81232012000300007

Ministério da Saúde. Secretaria Executiva. (2002). Programa Humanização do Parto: Humanização ao Pré-natal e Nascimento. Brasília, DF: Ministério da Saúde.

Ministério da Saúde. Secretaria de Atenção à Saúde. (2004). Política Nacional de Atenção Integral à Saúde da Mulher. Brasília, DF: Ministério da Saúde.

Ministério da Saúde. Secretaria de Atenção á Saúde. (2010). Parto e nascimento domiciliar assistidos por parteiras tradicionais: Programa trabalhando com parteiras tradicionais e experiências exemplares. Brasília, DF: Ministério da Saúde.

Ministério da Saúde. (2011). Portaria $\mathrm{n}^{\mathrm{o}}$ 1.459, de 24 de junho de 2011. Institui, no âmbito do Sistema Único de Saúde - SUS, a Rede Cegonha: Diário Oficial da União, seção 1.

Ministério da Saúde. Secretaria de Atenção á Saúde. (2012a). Livro da Parteira Tradicional. Brasília, DF: Ministério da Saúde.

Ministério da Saúde. (2012b). Diretrizes e normas regulamentadoras de pesquisa envolvendo seres humanos. Resolução no 466/12 do Conselho Nacional de Saúde. Brasília, DF: Ministério da Saúde. 
Ministério da Saúde. (2015). Portaria $\mathrm{n}^{\circ}$ 11, de 07 de janeiro de 2015. Redefine as diretrizes para implementação e habilitação para o Centro de parto Normal (CPN) no âmbito do SUS, para atendimento á mulher e ao recém-nascido no momento do parto e nascimento, em conformidade com a Rede Cegonha. Brasília-DF: Diário Oficial da União, seção 1.

Ministério da Saúde. (2016a). Protocolo clínico de diretrizes terapêuticas para cesariana. Brasília-DF: Diário Oficial da União, seção 1.

Ministério da Saúde. (2016b). Diretrizes e normas regulamentadoras de pesquisa envolvendo seres humanos. Resolução $\mathrm{n}^{\circ}$ 510/16 do Conselho Nacional de Saúde. Brasília, DF: Ministério da Saúde.

Ministério da Saúde. (2017). Diretrizes Nacional de assistência ao parto normal. Portaria ${ }^{\circ}$ 353/2017do Conselho Nacional de Saúde. Brasília, DF: Ministério da Saúde.

Moreira, M. E. L., Gama, S. G. N., Pereira, A. P. E., Silva, A. A. M., Lansky, S., Pinheiro, R. S., ... Leal, M. C. (2014). Práticas de atenção hospitalar ao recém-nascido saudável no Brasil. Cadernos de Saúde Pública,30(Supl. 1), S128-S139, doi:10.1590/0102$311 \mathrm{X} 00145213$

Nakano, A. R., B., Bonan, C., \& Teixeira, L. A. (2016). Cesárea, aperfeiçoando a técnica e normatizando a prática: uma análise do livro Obstetrícia, de Jorge de Rezende. História, Ciências, Saúde-Manguinhos, 23(1), 155-172, doi:10.1590/S0104-59702016000100010

Odashima, M. H. G., Cavaca, A. G., Oliveira, A. E., Silva, T. M., \& Santos Neto, E. T. (2019). O parto na TV: um olhar sob a perspectiva de Ivan Illich. Interface Comunicação, Saúde, Educação, 23, e180171, doi:10.1590/interface.180171

Odent, M. (2000). A Cientificação do Amor. São Paulo, SP: Terceira Margem.

Odent, M. (2002). Renascimento do Parto. Florianópolis, SC: Saint Germain.

Odent, M. (2016). Pode a Humanidade Sobreviver a Medicina. Rio de Janeiro, RJ: Instituto Michel Odent.

Oliveira, M. S. M. (2014). Protagonismo feminino no processo de escolha da via de parto. (Dissertação de Mestrado). https://pospsi.ufba.br/sites/pospsi.ufba.br/files/marianna_simoes.pdf

Organização Mundial da Saúde. (2015). Human reproduction programme. Declaração da OMS sobre taxas de cesáreas. Genebra, Suíça. Recuperado de http://apps.who.int/iris/bitstream/10665/161442/3/WHO_RHR_15.02_por.pdf

Peppe, M. V. (2017). A assistência puerperal prestada pelas enfermeiras obstetras elou obstetrizes que realizam o parto domiciliar planejado no estado de São Paulo (Dissertação de Mestrado). $\quad$ Recuperado de https://teses.usp.br/teses/disponiveis/22/22133/tde-29032018-151158/en.php 
Pereira, R. R., Franco, S. C. \& Baldin, N. (2011). A dor e o protagonismo da mulher na parturição. Revista Brasileira de Anestesiologia, 61(3), 382-388, doi:10.1590/S003470942011000300014

Pereira, C. A. (2018). A mídia na Ciência da Informação. Transinformação, 30(2), 141152, doi:10.1590/2318-08892018000200001

Pereira, R. M., Fonseca, G. O., Costa Pereira, A. C. C., Gonçalves, G. A., \& Mafra, R. A. (2018). Novas práticas de atenção ao parto e os desafios para a humanização da assistência nas regiões sul e sudeste do Brasil. Ciência \& Saúde Coletiva, 23(11), 35173524, doi:10.1590/1413-812320182311.07832016

Pimenta, D. G. et al. (2013). El parto realizado por matronas: una revisión integradora. Enfermería global, 12 (30), 482-493

Plastino, C. A. (2018). Fantasia, criatividade e realidade no pensamento de Winnicott. Revista Trágica: Estudos de Filosofia da Imanência, 11(1), 11-36.

Pompeu, K. C. Parindo em casa no Brasil: construção de redes entre as equipes de atenção ao parto domiciliar planejado. 2019. 89f. (Dissertação de Mestrado). Recuperado de http://bdtd.ibict.br/vufind/Record/UFN-1_75f5e785aa7a4198e1d680009415fab3

Porte, M. (2005). Rito e ritual. In Dicionário Internacional de Psicanálise. Rio de Janeiro, RJ: Imago.

Prates, L. A., Timm, M. S., Wilhelm, L. A., Cremonese, L., Oliveira, G., Schimith, M. D., \& Ressel, L. B. (2018). Being born at home is natural: care rituals for home birth. Revista Brasileira de Enfermagem, 71(Suppl. 3), 1247-1256, doi:10.1590/0034-7167-2017-0541

Ribeiro, R. A. O. (2010). Romantismo: contextualização Histórica e das Artes. (Dissertação de Mestrado). Recuperado de https://ziladoc.com/download/romantismo-contextualizaaohistorica-e-das-artes_pdf

Riesco, M. L. G. (2014). Nascer no Brasil "em tempo": uma questão de hierarquia das intervenções no parto? Cadernos de Saúde Pública,30(Supl. 1), S35S36, doi:10.1590/0102-311XCO02S114

Riscado, L. C., Jannotti, C. B., \& Barbosa, R. H. S. (2016). A Decisão pela via de parto no Brasil: temas e tendências na produção da saúde coletiva. Texto \& Contexto Enfermagem, 25(1), e3570014, doi:10.1590/0104-0707201600003570014

Russo, J., Nucci, M., Silva, F. L. \& Chazan, L. K. (2019). Escalando vulcões: a releitura da dor no parto humanizado. Mana, 25(2), 519-550, doi:10.1590/1678-49442019v25n2p519

Salgado, H. O. (2012). A experiência da cesárea indesejada: perspectiva das mulheres sobre decisões e suas implicações no parto e nascimento. (Dissertação de Mestrado). Recuperado de https://www.teses.usp.br/teses/disponiveis/6/6136/tde-28012013160810/pt-br.php 
Sanfelice, C. F. O. \& Shimo, A. K. K. (2014). Home childbirth: progress or retrocession?. Revista Gaúcha de Enfermagem, 35(1), 157-160, doi:10.1590/1983-1447.2014.01.41356

Santos, T. P. C. (2018). Vivência de mulheres em relação a dor do trabalho de parto: estudo qualitativo. (Dissertação de Mestrado). Recuperado de http://repositorio.unicamp.br/jspui/handle/REPOSIP/332302

Safra, G. (2004). A Po-Ética na Clínica Contemporânea. São Paulo, SP: Ideias \& Letras.

Safra, G. (2006). Hermenêutica na Situação Clínica. São Paulo, SP: Edições Sobornost.

Safra, G.(2008). A dor como revelação do ser e da dignidade humana. In A. Hoffmann, M. Massimi \& L. M. Oliveira. (Orgs.) Reflexões em torno da dor (pp. 197-204). Ribeirão Preto, SP: Fapesp - Grupo São Francisco.

Scarton, J., Prates, L. A., Wilhelm, L. A., Silva, S. C., Possati, A. B., Ilha, C. B., \& Ressel, L. B. (2015). "No final compensa ver o rostinho dele": vivências de mulheres-primíparas no parto normal. Revista Gaúcha de Enfermagem,36(spe), 143-151, doi:10.1590/19831447.2015.esp.56786

Segal, J. (2005). Conceitos da Psicanálise: Fantasia. São Paulo, SP: Ediouro.

Serruya, S. J. (2014). A arte de não fazer o errado e fazer o certo! Cadernos de Saúde Pública, 30(Supl. 1), S36-S37, doi:10.1590/0102-311XCO03S114

Serviço Nacional de Saúde (2018). Novas recomendações da OMS para o parto. Recuperado de https://www.sns.gov.pt/noticias/2018/02/20/parto-novas-recomendacoes-da-oms/

Silva, A. A. M., Leite, A. J. M., Lamy, Z. C., Moreira, M. E. L., Gurgel, R. Q., Cunha, A. J. L. A., \& Leal, M. C. (2014). Morbidade neonatal near miss na pesquisa Nascer no Brasil. Cadernos de Saúde Pública,30(Supl. 1), S182-S191, doi:10.1590/0102$311 X 00129613$

Souza, J. P., \& Pileggi-Castro, C. (2014). Sobre o parto e o nascer: a importância da prevenção quaternária. Cadernos de Saúde Pública,30(Supl. 1), S11S13, doi:10.1590/0102-311XPE02S114

Szejer, M. (1999). Palavras para nascer: a escuta psicanalítica na maternidade. São Paulo, SP: Casa do Psicólogo.

Tempesta, G. A. \& Carneiro, R. G. (2018). Para adentrar o portal da dor do parto: corpo, gênero e significações heterogêneas em contextos diversos. Revista Social Gênero. 11(2), doi:10.224009/rg.v18i2.1142

Torres, J. A., Domingues, R. M. S. M., Sandall, J., Hartz, Z., Gama, S. G. N., Theme Filha, M. M., ... Leal, M. C. (2014). Cesariana e resultados neonatais em hospitais privados no Brasil: estudo comparativo de dois diferentes modelos de atenção perinatal. Cadernos de Saúde Pública,30(Supl. 1), S220-S231, doi:10.1590/0102-311X00129813 
Vasconcellos, M. T. L., Silva, P. L. N., Pereira, A. P. E., Schilithz, A. O. C., Souza Junior, P. R. B., \& Szwarcwald, C. L. (2014). Desenho da amostra Nascer no Brasil: Pesquisa Nacional sobre Parto e Nascimento. Cadernos de Saúde Pública, 30(Suppl. 1), S49-S58, doi:10.1590/0102-311X00176013

Velho, M. B., Santos, E. K. A., Brüggemann, O. M., \& Camargo, B. V. (2012). Vivência do parto normal ou cesáreo: revisão integrativa sobre a percepção de mulheres. Texto \& Contexto - Enfermagem, 21(2), 458-466, doi:10.1590/S0104-07072012000200026

World Health Organization. (2018). Recommendations: intrapartum care for a positive childbirth experience. Geneva: World Health Organization.

Winnicott, D. W. (1993). A defesa maníaca. In Da Pediatria à Psicanálise. Rio de Janeiro, RJ: Francisco Alves. (Trabalho original publicado em 1935).

Winnicott, D. W. (1993). Desenvolvimento emocional primitivo. In Da Pediatria à Psicanálise. Rio de Janeiro, RJ: Francisco Alves. (Trabalho original publicado em 1945).

Winnicott, D. W. (1993). Preocupação materna primária. In Da Pediatria à Psicanálise. Rio de Janeiro, RJ: Francisco Alves. (Trabalho original publicado em 1956).

Winnicott, D. W. (2006). A contribuição da psicanálise à obstetrícia. In Os bebês e suas mães. São Paulo, SP: Martins Fontes. (Trabalho original publicado em 1965).

Winnicott, D. W. (2008). Teoria do relacionamento paterno-infantil. In $O$ ambiente e os processos de maturação. Porto Alegre, RS: Artmed. (Trabalho original publicado em 1960).

Winnicott, D. W. (2008). A integração do ego no desenvolvimento da criança. In $O$ ambiente e os processos de maturação. Porto Alegre, RS: Artmed. (Trabalho original publicado em 1962).

Winnicott, D. W. (2008). O desenvolvimento da capacidade de se preocupar. In $O$ ambiente $e$ os processos de maturação. Porto Alegre, RS: Artmed. (Trabalho original publicado em 1963a).

Winnicott, D. W. (2008). Da dependência à independência no desenvolvimento do individuo. In $O$ ambiente e os processos de maturação. Porto Alegre, RS: Artmed. (Trabalho original publicado em 1963b).

Winnicott, D. W. (2013). Fatores de integração e desintegração na vida familiar. In A família $e$ o desenvolvimento individual. São Paulo, SP: Martins Fontes. (Trabalho original publicado em 1957).

Winnicott, D. W. (2013). Família e maturidade emocional. In A família e o desenvolvimento individual. São Paulo, SP: Martins Fontes. (Trabalho original publicado em 1960).

Winnicott, D. W. (2016). Este feminismo. In Tudo começa em casa. São Paulo, SP: Martins Fontes. (Trabalho original publicado em 1964). 
Winnicott, D. W. (2016). Contribuição da mãe para a sociedade. In Tudo começa em casa. São Paulo, SP: Martins Fontes. (Trabalho original publicado em 1957). 
APÊNDICES 


\section{APÊNDICE A}

\section{TERMO DE CONSENTIMENTO LIVRE E ESCLARECIDO}

Olá,

Meu nome é Lydiane Bocamino, sou psicóloga e mestranda na Faculdade de Filosofia Ciências e Letras de Ribeirão Preto, da Universidade de São Paulo (FFCLRP - USP). Você está sendo convidada a participar voluntariamente da pesquisa que estou desenvolvendo "Meu filho nasceu em casa": compreendendo a experiência de mulheres que optaram pelo parto domiciliar planejado, orientada pela $\operatorname{Prof}^{a} \mathrm{Dr}^{\mathrm{a}}$ Cármen Lúcia Cardoso, docente da mesma instituição.

Atualmente muitas mulheres têm optado pelo parto domiciliar planejado e essa escolha tem provocado novos comportamentos, valores e sentimentos tanto nas famílias quanto nos profissionais. Assim, o objetivo dessa pesquisa é compreender a experiência de mulheres que optaram por esse tipo de parto, a partir de sua própria perspectiva. A produção científica nessa área ainda é escassa, dessa forma, o presente estudo possui uma relevância científica e social e pode contribuir para construção de conhecimento nessa área e trazer benefícios à comunidade científica e à sociedade.

É importante esclarecer que sua participação é voluntária, não havendo pagamento por ela, mas também não haverá nenhum custo. Caso haja alguma despesa não prevista, haverá ressarcimento integral da quantia despendida.

Sua participação se dará através de uma entrevista com o tempo aproximado de uma hora. O local será combinado entre nós, podendo ser em seu próprio domicílio ou em outro lugar, se assim preferir. Sua identidade não será revelada publicamente e seu nome não aparecerá no final do trabalho. As entrevistas serão individuais, áudio-gravadas e transcritas para que sejam utilizadas nas futuras publicações dos resultados deste estudo.

Os riscos em participar desta pesquisa são muito pequenos. Caso você sinta algum desconforto em responder a entrevista, terá total liberdade para interrompê-la ou para desistir da sua participação nesse estudo em qualquer momento, por qualquer motivo, sem que isso implique em qualquer prejuízo, tendo suas informações inutilizadas.

Caso seja necessário, poderá ser feito um encaminhamento para serviços de atendimento psicológico gratuito de Ribeirão Preto, sendo que eu ficarei responsável por acompanhá-la e orientá-la até que o atendimento se inicie.

Para finalizar esse estudo será realizada uma devolutiva com as participantes, em grupo, com o objetivo de apresentar os resultados obtidos. A data e o local ainda serão combinados. 
Você deverá assinar duas vias deste Termo de Consentimento, devendo ficar com uma delas e me devolvendo a outra para eu possa arquivá-la.

Qualquer dúvida poderá ser esclarecida antes, durante ou após a realização desse estudo, tanto comigo quanto com a $\operatorname{Prof}^{a} \operatorname{Dr}^{a}$ Carmen Lúcia Cardoso, no endereço:

Av. Bandeirantes, $\mathrm{n}^{\circ} 3900$

Departamento de Psicologia da FFCLRP-USP - Bloco 5 - sala 33A

Ribeirão Preto - SP - CEP: 14040-901

Fone: (16) 3315-3660

O Comitê de Ética em Pesquisa da FFCLRP-USP poderá ser contato em caso de dúvidas, reclamações e/ou denúncias com relação às questões éticas dessa pesquisa. Os dados para contato com o Comitê de Ética são os que se seguem:

Avenida Bandeirantes, $\mathrm{n}^{\circ} 3900$

Bloco 23 - Casa 37

Ribeirão Preto - SP - CEP: 14040-901

Fone: (16) 3315-4811

E-mail: coetp@ffclrp.usp.br

Obrigada pela sua atenção e colaboração!

$\mathrm{Eu}$, declaro que li este documento e confirmo que entendi as informações apresentadas. Também declaro que recebi uma via assinada e datada deste termo. Diante disso, aceito participar voluntariamente desse estudo.

Ribeirão Preto, de de 201

Lydiane Bocamino Pesquisadora responsável (16) $98117-6861$

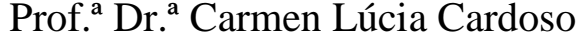
Orientadora (16) 3315-3660 


\section{APÊNDICE B}

\section{Roteiro de Entrevista}

Nome:

Data de nascimento:

Estado civil:

Escolaridade:

Profissão:

Horas semanais de trabalho:

Endereço:

Telefone: E-mail:

Renda familiar: Número de filhos:

Renda Pessoal:

Nome do(a) filho(a)

Data do parto domiciliar: Semanas Gestacionais:

Nome do(a) filho(a):

Data do parto domiciliar: Semanas Gestacionais:

Data da entrevista:

Pessoas com as quais reside:

\begin{tabular}{|l|l|l|l|l|}
\hline Nome & Parentesco & $\begin{array}{c}\text { Data } \\
\text { nascimento }\end{array}$ & Escolaridade & Profissão \\
\hline & & & & \\
\hline & & & & \\
\hline & & & & \\
\hline & & & & \\
\hline
\end{tabular}


Questão disparadora: "Gostaria que você me contasse como foi sua experiência de ter realizado um parto domiciliar planejado".

\section{Temas a serem abordados:}

1. Vínculo conjugal, histórico gestacional e de parto.

2. Motivos pelos quais optou pelo parto domiciliar.

3. Presença ou ausência de apoio familiar.

4. Preparação para o parto.

5. Evento do parto domiciliar. 


\section{APÊNDICE C}

\section{Quadro A}

\begin{tabular}{|c|c|c|c|c|c|}
\hline Nome & Idade & $\begin{array}{l}\text { Estado } \\
\text { civil }\end{array}$ & Escolaridade & $\begin{array}{l}\text { Histórico das } \\
\text { gestações }\end{array}$ & $\begin{array}{l}\text { Renda } \\
\text { Familiar }\end{array}$ \\
\hline ALFAZEMA & 35 anos & $\begin{array}{l}\text { União } \\
\text { estável }\end{array}$ & Doutorado & $\begin{array}{l}2 \text { gestações, } 2 \text { filhos } \\
1^{\mathrm{a}}-\mathrm{PNH} \\
2^{\mathrm{a}}-\mathrm{PDP}\end{array}$ & $8 \mathrm{SM}$ \\
\hline AMARÍLIS & 36 anos & Casada & $\begin{array}{l}\text { Superior } \\
\text { completo }\end{array}$ & $\begin{array}{l}4 \text { gestações, } 3 \text { filhos } \\
1^{\text {a }}-\text { PNH } \\
2^{\text {a }}-\text { Aborto } \\
3^{\mathrm{a}}-\mathrm{PDP} \\
4^{\mathrm{a}}-\mathrm{PDP}\end{array}$ & $8 \mathrm{SM}$ \\
\hline AZALÉIA & 38 anos & Casada & $\begin{array}{l}\text { Superior } \\
\text { completo }\end{array}$ & $\begin{array}{l}2 \text { gestações, } 1 \text { filha } \\
1^{\mathrm{a}}-\text { Aborto } \\
2^{\mathrm{a}}-\mathrm{PDP}\end{array}$ & $7 \mathrm{SM}$ \\
\hline BEGÔNIA & 31 anos & Casada & $\begin{array}{l}\text { Superior } \\
\text { completo }\end{array}$ & $\begin{array}{l}3 \text { gestações, 1 filho } \\
1^{\text {a }}-\text { Aborto } \\
2^{\text {a }}-\text { Aborto } \\
3^{\text {a }}-\text { PDP }\end{array}$ & $12 \mathrm{SM}$ \\
\hline BROMÉLIA & 42 anos & Casada & $\begin{array}{l}\text { Superior } \\
\text { completo }\end{array}$ & $\begin{array}{l}4 \text { gestações, } 2 \text { filhos } \\
1^{\mathrm{a}}-\text { Aborto } \\
2^{\mathrm{a}}-\mathrm{PDP} \\
3^{\mathrm{a}}-\text { Aborto } \\
4^{\mathrm{a}}-\mathrm{PDP}\end{array}$ & $40 \mathrm{SM}$ \\
\hline DÁLIA & 32 anos & Casada & Pós-graduação & $\begin{array}{l}2 \text { gestações, } 2 \text { filhos } \\
1^{\mathrm{a}}-\text { PDP } \\
2^{\mathrm{a}}-\text { Cesárea }\end{array}$ & $14 \mathrm{SM}$ \\
\hline GÉRBERA & 40 anos & Casada & $\begin{array}{l}\text { Superior } \\
\text { completo }\end{array}$ & $\begin{array}{l}3 \text { gestações, } 3 \text { filhos } \\
\\
1^{\text {a }}-\text { PNH } \\
2^{\text {a }}-\text { PNH } \\
3^{\text {a }- \text { PDP }}\end{array}$ & $5 \mathrm{SM}$ \\
\hline HORTÊNCIA & 37 anos & Casada & Doutorado & $\begin{array}{l}3 \text { gestações, } 2 \text { filhos } \\
1^{\mathrm{a}}-\mathrm{PNH} \\
2^{\mathrm{a}}-\mathrm{PDP} \\
3^{\mathrm{a}}-\text { Aborto }\end{array}$ & $8 \mathrm{SM}$ \\
\hline
\end{tabular}




\begin{tabular}{|c|c|c|c|c|c|}
\hline JASMIM & 32 anos & Casada & $\begin{array}{l}\text { Superior } \\
\text { completo }\end{array}$ & $\begin{array}{l}2 \text { gestações, } 2 \text { filhos } \\
1^{\text {a }}-\text { PNH } \\
2^{\mathrm{a}}-\mathrm{PDP}\end{array}$ & $8 \mathrm{SM}$ \\
\hline LAVANDA & 41 anos & Casada & Mestranda & $\begin{array}{l}5 \text { gestações, } 2 \text { filhos } \\
1^{\text {a }}-\text { Aborto } \\
2^{a}-\text { Aborto } \\
3^{a}-\text { PNH } \\
4^{a}-\text { PDP } \\
5^{a}-\text { Está grávida }\end{array}$ & Acima de $5 \mathrm{SM}$ \\
\hline MARGARIGA & 35 anos & Casada & $\begin{array}{l}\text { Superior } \\
\text { completo }\end{array}$ & $\begin{array}{l}3 \text { gestações, } 2 \text { filhos } \\
1^{\mathrm{a}}-\mathrm{PDP} \\
2^{\mathrm{a}}-\mathrm{PDP} \\
3^{\mathrm{a}}-\text { Está grávida }\end{array}$ & $8 \mathrm{SM}$ \\
\hline MIMOSA & 28 anos & Casada & $\begin{array}{l}\text { Superior } \\
\text { completo }\end{array}$ & $\begin{array}{l}1 \text { gestação, } 1 \text { filha } \\
1^{\mathrm{a}}-\mathrm{PDP}\end{array}$ & $6 \mathrm{SM}$ \\
\hline ORQUÍDEA & 41 anos & Casada & Pós-graduação & $\begin{array}{l}2 \text { gestações, } 2 \text { filhos } \\
1^{\text {a }}-\text { Cesárea } \\
2^{\text {a }}-\text { PDP }\end{array}$ & $40 \mathrm{SM}$ \\
\hline PETÚNIA & 36 anos & $\begin{array}{l}\text { União } \\
\text { estável }\end{array}$ & $\begin{array}{l}\text { Superior } \\
\text { completo }\end{array}$ & $\begin{array}{l}2 \text { gestações, } 2 \text { filhos } \\
1^{\mathrm{a}}-\mathrm{PDP} \\
2^{\mathrm{a}}-\mathrm{PDP}\end{array}$ & Não informou \\
\hline ROSA & 35 anos & Casada & $\begin{array}{l}\text { Superior } \\
\text { completo }\end{array}$ & $\begin{array}{l}2 \text { gestações, } 2 \text { filhos } \\
1^{\text {a }}-\text { PDP } \\
2^{\text {a }}-\text { PDP }\end{array}$ & $10 \mathrm{SM}$ \\
\hline TULIPA & 35 anos & Casada & Mestrado & $\begin{array}{l}3 \text { gestações, } 3 \text { filhas } \\
1^{\text {a }}-\text { Cesárea } \\
2^{\mathrm{a}}-\mathrm{PNH} \\
3^{\mathrm{a}}-\mathrm{PDP}\end{array}$ & $7 \mathrm{SM}$ \\
\hline VIOLETA & 32 anos & Casada & $\begin{array}{l}\text { Superior } \\
\text { completo }\end{array}$ & $\begin{array}{l}2 \text { gestações, } 2 \text { filhos } \\
1^{\text {a }}-\text { PDP } \\
2^{a}-\text { PDP }\end{array}$ & $15 \mathrm{SM}$ \\
\hline
\end{tabular}

Quadro A. Descrição das participantes, de acordo com idade, estado civil, escolaridade, histórico das gestações e renda. PNH: Parto normal hospitalar; PDP: Parto domiciliar planejado e SM: Salários mínimos. 
ANEXO 


\begin{abstract}
ANEXOA
Universidade de São Paulo

Faculdade de Filosofia, Ciências e Letras de Ribeirão Preto Comitê de Ética em Pesquisa

Of.CEtP/FFCLRP-USP/039-dgfs. Campus de Ribeirão Preto
\end{abstract}

Ribeirão Preto, 26 de maio de 2017.

Prezado(a) Pesquisador(a),

Comunicamos a V. Sa. que o projeto de pesquisa intitulado "'Meu filho nasceu em casa': compreendendo a experiência de mulheres que optaram pelo parto domiciliar planejado" foi analisado pelo Comitê de Ética em Pesquisa da FFCLRP.USP, em sua $166^{\mathrm{a}}$ Reunião Ordinária, realizada em 25.05.2017, e enquadrado na categoria: APROVADO (CAAE $\left.n^{\circ} 66587617.7 .0000 .5407\right)$.

Solicitamos que eventuais modificações ou emendas ao projeto de pesquisa sejam apresentadas ao CEP, de forma sucinta, identificando a parte do projeto a ser modificada e suas justificativas. De acordo com a Resolução n466 de 12/12/2012, devem ser entregues relatórios semestrais e, ao término do estudo, um relatório final sempre via Plataforma Brasil.

Atenciosamente,

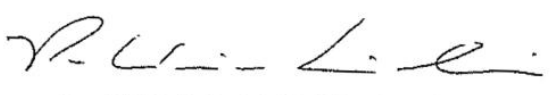

Prof. ${ }^{a}$ Dr. ${ }^{a}$ Patríciá Nicolucci Vice -'coordenadora

Ao(À) Senhor(a)

Lydiane Bocamino

Programa de Pós-graduação em Psicologia FFCLRP/USP.

CEP - Comitè de Ética em Pesquisa da FFCLRP USP

Fone: (16) $3315-4811$

Avenida Bandeirantes, 3900 - bloco 23 - casa 37 - 14040-901 - Ribeirão Preto - SP - Brasi

Homepage: http://www.ffclrp.usp.br - e-mail: coetp@ffclrp.usp.br 